\title{
Economic Fragmentation and FDI in China
}

\author{
By: Yasheng Huang
}

Working Paper Number 374

May 2001 
Economic Fragmentation and FDI in China

$$
\text { By: Yasheng Huang }
$$

Working Paper Number 374

May 2001 


\title{
Economic Fragmentation and FDI in China
}

\author{
Yasheng Huang \\ Associate Professor \\ Business, Government and International Economy \\ Harvard Business School \\ Boston, MA 02163 \\ Yhuang@hbs.edu
}

\begin{abstract}
China is one of the most popular investment destinations in the world. This paper argues that FDI inflows into China are in fact driven by some fundamental inefficiencies in the Chinese economy. Specifically, one of the inefficiencies has to do with a high level of fragmentation of both goods and asset markets. This fragmentation increases demand for FDI both because market fragmentation makes indigenous Chinese firms uncompetitive and because market fragmentation creates more investment opportunities for the mobile foreign capital. This paper is a chapter from a larger book-length research project, tentatively entitled, Selling China: The Institutional Foundation of Foreign Direct Investment During the Reform Era.
\end{abstract}

Keywords: FDI, capital market, transitional economies. 


\section{Summary of the book, Selling China: The Institutional Foundation of Foreign Direct Investment During the Reform Era}

China is one of the most popular investment destinations in the world. Throughout much of the 1990s, China accounted for 50 percent of foreign direct investment (FDI) going into developing countries and in recent years, China has been the second largest recipient of FDI in the world, after the United States. The recent agreements between China on the one hand and the United States and the European Union on the other hand over China's accession into the World Trade Organization (WTO) may increase China's already impressive FDI inflows significantly. According to a forecast by Goldman Sachs, in three to four years, China's WTO membership could boost FDI to 100 billion dollars a year, from the current 40.4 billion dollars.

Chinese officials and foreign business practitioners hail China's large FDI inflows as one of the most celebrated achievements of the reform era. Institutions such as the World Bank have credited FDI as a main driving force behind China's economic success. International rating agencies routinely use FDI flows as an important macroeconomic indicator to assess China's creditworthiness. Standard \& Poor's, for example, in its most recent report on China's credit rating, cited "strong inflows of foreign direct investments" as one of the factors to justify an upgrade of China's credit ratings. Academic researchers are equally enthusiastic about FDI flows into China. They tout the enormous benefits of FDI for China, such as technology transfer, the introduction of marketing know-how, capital infusion, etc.

This book sets out to debunk much of the conventional wisdom on China's huge FDI inflows. The central claim of the book is that the large absorption of FDI by China is not a sign of the strengths of its economy but of its fundamental weaknesses. Three lines of argument are advanced to support this claim. First, much of the export-oriented FDI-mainly originating from ethnic Chinese firms in Hong Kong, Macao, and Taiwan-materializes because of the severe liquidity constraints on the part of export-oriented indigenous Chinese firms. These liquidity constraints arise not because export-oriented Chinese firms are inefficient but because they are private and for years Chinese banks were explicitly prohibited from lending to private firms. Private firms have no choice but to raise financing in the only way they can—selling their claims on future cash flows to foreign firms. FDI rises as a result.

Second, much of the FDI oriented toward the domestic market—mainly in capitalintensive industries - does not finance the creation of new capacity but finances the acquisition of existing assets, mainly from state-owned enterprises (SOEs). SOEs have accumulated massive 
financial losses and huge liabilities on their balance sheets. The insolvency of SOEs is a familiar story. What is not familiar is the fact that SOEs have built up a potentially valuable asset base during the reform era, which was financed by a generous infusion of subsidized credit from the banking system. On top of a good asset base, SOEs have generated poor or negative returns, which renders them potential acquisition targets. Because the Chinese government still refuses to adopt a privatization policy to deal with the SOE insolvency situation, the only viable acquirers end up being foreign firms. FDI rises on this account. Third, China's capital and product markets are severely fragmented, which means that a Chinese firm located in Province A cannot invest in Province B. The economic fragmentation gives an enormous advantage to foreign firms, which are not faced by similar capital constraints. FDI rises on this account because foreign firms can choose more projects to invest in than domestic firms. In brief, FDI inflows rise in response to either market growth opportunities or to labor-cost saving opportunities only because indigenous firms are uncompetitive across-the-board and are unable to respond to the same set of opportunities.

A number of aspects of the research set this project apart from others. One is that an explicit theoretical framework guides much of the empirical research. The book offers what is termed as an "institutional foundation" perspective on FDI. The institutional foundation argument both builds upon and departs from the dominant theoretical approach in the studies of FDI, which is known as the industrial organization theory of FDI. The commonality is a microeconomic reasoning that FDI, as an ownership arrangement, is designed to overcome certain problems inherent in arms-length contractual transactions. The departure has to do with what constitutes the sources of problems besetting contractual transactions. While the industrial organization theory focuses on market failures involved in transactions of certain resources endowed with unique characteristics (such as indivisibility or asset-specificity), the institutional foundation argument focuses on the failures resulting from imperfectly-designed financial and economic institutions in allocating all goods and resources. Furthermore, these failures are not a result of characteristics of goods or resources being transacted but as a result of deliberate policy and political choices of the government.

The second departure directly follows from the first. While much of the works on FDI studies the motivations and capabilities of foreign investing firms, this study tries to understand the motivations, constraints and capabilities of the Chinese host firms and local governments. The empirical emphasis is based on a conceptualization of FDI that views FDI as a function of relative, rather than as absolute, competitiveness of foreign firms. Relative foreign 
competitiveness is, in turn, a function of foreign competitiveness and domestic

uncompetitiveness. As such, studying domestic uncompetitiveness should be just as analytically rewarding as studying foreign competitiveness. This way of researching FDI has been surprisingly rare among existing studies.

Although the overall objective is to explain FDI patterns in China, the analytical framework of the book revolves around the design and operations of key economic and financial institutions in China in affecting China's FDI patterns. As such, the book offers a broad reinterpretation not only of FDI in China but also of the Chinese economic reforms. This latter aspect of the book should interest those readers who are interested in China's reform process and in the lessons one can draw from the Chinese reforms relevant to other reforming socialist economies. In recent years, the Chinese gradualist reform strategy has been held up as a model for countries trying to transform themselves into market economies. This book questions this perspective. It shows that the partial reforms, while successful in increasing the scope of market, have so far failed to address the fundamental inefficiencies in the Chinese economy and one reason why China has averted an economic meltdown is because of the large infusions of FDI rather than because of the success of China's reform strategy.

In this working paper, I only focus on one of the institutional pillars underlying much of the FDI developments in the 1990s. This paper first describes the fragmentation of the Chinese economy. Economic fragmentation has a strong bearing on Chinese FDI demand. It reduces the set of investment opportunities available to Chinese firms, while increasing the set of investment opportunities available to foreign firms. FDI rises because foreign firms are more successful than Chinese firms in capturing these investment opportunities. The paper presents both quantitative and case-study evidence to document this phenomenon. (This paper appears as Chapter 4 in the book.) 


\section{Economic fragmentation and FDI}

MNCs are not only multinational; they are, first and foremost, multi-regional in China. Motorola, Schindler, Otis, Volkswagen, Ford, Nabisco, etc. have all established operations across the country and increasingly Western MNCs are creating a holding company structure to coordinate their complex activities and interactions among their subsidiaries or affiliates and to economize on the shared overhead costs. These cross-regional investments or acquisitions are not limited to the Fortune 500 corporations; in fact much smaller MNCs have actively acquired assets throughout the country. A prominent example is the Hong Kong based China Strategic Investment Ltd. China Strategic Investment, with sale revenue of only 84 million dollars in 1992, acquired 200 companies throughout China during a span of two years between 1992 and 1994. Its joint ventures are located in more than nine provinces and its China Tires Holdings, via its acquisitions of tire plants in five provinces, emerged to be the largest tire producer in China in

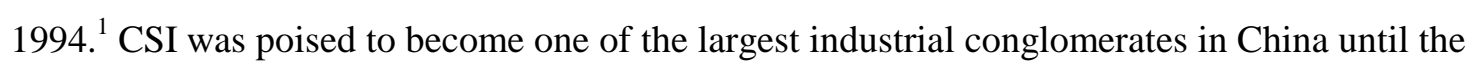
central government intervened to put a brake on its acquisition bids in 1995 .

Our question, as always, is, "Why can't Chinese companies do the same?" We already provided one answer in Chapter 2 and Chapter 3: Because the government has refused to allow SOEs to be privatized, Chinese non-state firms cannot acquire loss-making SOEs while MNCs can via what I call a "JV acquisition" mechanism. But clearly this is not the whole answer because Chinese SOEs do not acquire other SOEs either. SOE acquisition by other SOEs clearly does not entail any ideological complications and yet this type of acquisitions has been rare, especially acquisitions involving firms from different jurisdictions. The paucity of acquisitions is even more puzzling considering the following two facts. First, Chinese firms and government agencies have been investing massively to build new plants and facilities. Between 1991 and 1998, for three out of those eight years, investment/GDP ratio exceeded 40 percent and for six out of these eight years, the investment/GDP ratio exceeded 38 percent. Reform era is sometimes touted as heralding a shift from heavy to light industry. In fact, this never happened. As a

\footnotetext{
${ }^{1}$ See (Lim 1994).
}

${ }^{2}$ All of the acquisitions by CSI were JV acquisitions, i.e., CSI contributed cash while the target firms contributed themselves as equity stakes in the newly formed FIEs. The regional governments then owned these FIEs proportionate to the valuation of these contributed firms themselves. 
comparison, between 1978 and 1985, for seven out of eight years, investment/GDP ratio was lower than 38 percent.

Second, during much of the 1990s, Chinese economy has suffered from a chronic overcapacity, especially in its manufacturing industries. According to a Chinese researcher who analyzed the data from Third Industry Census in 1995, of ninety-four industrial products, thirtyfive products, or 36 percent, had a capacity utilization rate at or below 50 percent. 4 Automotive industry, the focus of analysis in this chapter, has one of the most severe overcapacity problems. In truck production, in 1995, capacity utilization rate was 36 percent; bus production, 29.8

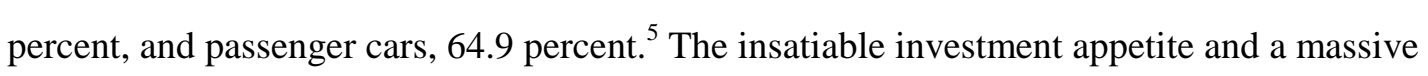
buildup of excess capacity are sure a strange combination. As I pointed out in Chapter 3, MNCs in the 1990s resorted to mainly asset acquisitions — whether direct or via JV—as an entry strategy. They were doing exactly the right thing considering the extent of excess capacity in the Chinese economy. What is puzzling is why Chinese firms have favored building facilities from scratch when asset acquisitions might have been a cheaper option. This gets to the third pillar of our institutional foundation argument—economic and asset fragmentation in the Chinese economy.

At purchasing power parity (PPP), Chinese GNP in 1998 was estimated to be 3.98 trillion dollars, which makes China the second largest economy in the world, after the United States (7.92 trillion dollars) and before Japan (2.93 trillion dollars). Dividing 3.98 trillion dollars by 31 - the number of Chinese provinces. One gets 128 billion dollars. That is about the size of

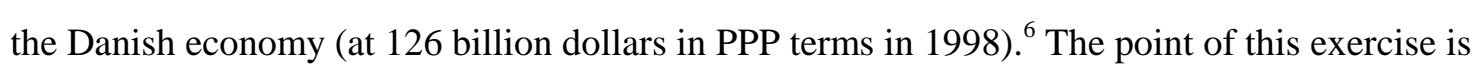
to show that there is a big difference between a market that is integrated and one that is fragmented. For any MNC contemplating an investment in China, it is not negotiating with a government or a firm representing the second largest economy in the world but with one that represents only a fraction of it. Chinese economy is remarkably fragmented and has become more

${ }^{3}$ The investment/GDP ratio data are contained in (State Statistical Bureau 1999).

${ }^{4}$ See (Zhao 1997).

${ }^{5}$ Data are from (Office of Third Industrial Census 1997).

${ }^{6}$ The GNP figures in purchasing power parity terms are from Table 1, (World Bank 2000). It is important to note that different PPP estimates exist. For example, the widely-cited Penn World Table estimates Chinese GNP at xxx in its PPP calculation. PPP calculations vary across different estimates because they are based on different assumptions about what are relevant price levels. 
fragmented over time. One needs to recognize this fact in order to understand the distribution of bargaining power between an MNC and the Chinese entity it is negotiating with.

Let me begin by noting a number of curious economic facts: While during the reform era Chinese have begun to trade actively with outside world and enthusiastically court foreign investments, Chinese have increasingly traded less with each other and invested less outside their home provinces. The tiny Macao, in 1994, held an investment position in China that amounted to several multiples of what Guangdong province invested outside Guangdong. That China has a fragmented economic structure is not news to students of Chinese economy; what may be new is the remarkable extent of its economic fragmentation juxtaposed on top of rapidly increasing economic and investment ties to the outside world. In 1985, external trade/GDP ratio rose from 25 percent to 40 percent; during the same period, internal trade/retail sale ratio declined from 60

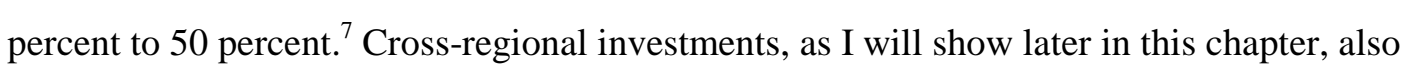
declined during the reform era while inward FDI climbed up rapidly.

The main claim of this chapter is that there is a connection between these two developments. Economic fragmentation has made FDI more valuable to the Chinese than otherwise would be the case. The simplest illustration of this logic comes from the world of sports. In the United States, the National Football League (NFL) deliberately restricts the number of football teams to a fewer number than the cities that desire to have them. As a result, cities compete fiercely with each other to lure a team to them. They offer huge financial subsidies to build stadiums and they top each other's offer aggressively. The result is that the teams and their owners are richly rewarded and exercise an enormous bargaining power over their host cities.

Economic fragmentation does to Chinese firms what National Football League does to the American cities desiring to have a home team of their own — by reducing their bargaining power vis-à-vis investing foreign firms. Economic fragmentation is complemented and reinforced by asset fragmentation. Assets are owned by disparate political rather than economic units. The first and foremost manifestation of the political control is that a vast majority of SOEs are under the direct controls of regional governments. "Control" here means broadly de facto ownership rights - the rights to make crucial decisions, to receive residual cash flows and to dispose of assets. In 1995, there were 87,905 industrial SOEs, of which 83,167 were owned by the regional

\footnotetext{
${ }^{7}$ See (World Bank 1994, p. 3).

${ }^{8}$ This example as well as the reasoning about bargaining power come from (Brandenburger and
} Nalebuff 1997). 
governments. The locally-owned SOEs accounted for 65 percent of the total SOE assets and 64

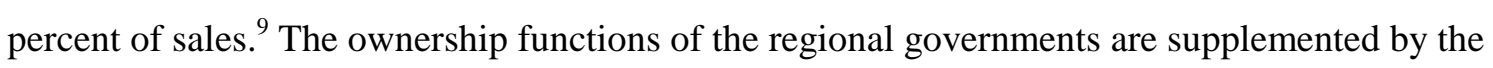
broad regulatory power in their hands. Despite central policy prohibitions, it is widely known that local governments set up trade barriers against inter-regional trade as well as to curtail capital exports. But foreign firms are not constrained by the capital controls imposed by the regional governments and are relatively free to invest where an investment opportunity presents itself. This dynamic allows a firm such as CSI to acquire assets in China on an unprecedented scale.

The chapter begins by providing a detailed account of the phenomenon of economic fragmentation. This is followed by studying a classic case of economic fragmentation-China's automotive industry, an industry which, by its economic logic, is extremely concentrated everywhere else in the world, except in China. The last section presents hypotheses and evidence connecting economic fragmentation with FDI demand.

\section{Economic fragmentation}

Chinese economy has been variously described as a "cellular" economy, 10 federalism, Chinese style, 1, or de facto federalism. ${ }^{2}$ However it is phrased, the basic idea is that China has a decentralized economic structure and under this system each region is quite operationally and financially autonomous, as if it were a profit center in a firm. It ought be stressed that this system departed sharply from the traditional Soviet model not only in a number of specific planning practices but rather fundamentally in the operational principle that governed the two economic organizations. The Soviet system organized its economic activities on a sectoral basis, i.e., one government agency, usually a ministry, governed most activities in one sector across different geographic boundaries. This is known as the vertical management principle in Chinese economic literature (or the "branch management" principle in Soviet economic literature). The Chinese system was and, to a large extent, still is based upon territorial or regional planning, i.e., one government agency--the local government--governs most economic activities in one geographic

\footnotetext{
${ }^{9}$ The data are from the 1995 industrial census. See (Office of Third Industrial Census 1997).

${ }^{10}$ (Donnithorne 1981 ).

11 [Montinola, Forthcoming \#1255].

12 (Huang 1996).
} 
region across different economic sectors. This is known as the horizontal management principle. 13

\section{One country, thirty-one markets}

As an administrative entity, China is divided into thirty-one provinces. ${ }^{14}$ Each province in turn consists of prefectures, cities, counties, and townships. As of 1998, altogether there were 331 prefectures, 2,126 counties and 26,400 townships. Because Chinese political system is unitary in nature, a strict hierarchy prevails. Provincial governments appoint heads of prefectures or cities, who, in turn, appoint magistrates of counties and townships. By any standard, this is a massive and highly centralized political apparatus.

In contrast to the political centralization, Chinese economy comprises of many independent and poorly-integrated segments. Market segmentation means that goods, services and factors of production — capital and labor-are not easily mobile across different regions. The immobility of goods and capital is typically gauged by variations in prices of goods and in returns on capital across different regions. Here indicators are many and are consistent among themselves in pointing to the same direction. The World Bank, in probably the most comprehensive study of this issue to date, presented data for the early 1990s showing large variations in prices across provinces. For example, the "all China" price of steel in 1991 was 1,984 yuan, with a minimum price of 1,857 yuan (Hebei) and a maximum of 2,435 yuan (Chongqing city). More systematic evidence shows the same trend. Between 1986 and 1991, for seven broad categories of consumer goods, regional variations in prices increased, although for some of the products, there was some reduction in price variations during this period. Another evidence—returns on capital—points to the same direction. Although there has been some reduction in variations in profit rates across different industrial sectors, variations in returns on capital across Chinese provinces increased between 1985 and 1991. After controlling for

\footnotetext{
13 See (Huang 1994 ) for more details of this argument. The choice of one organizing principle over another is beyond the scope of this book. Suffice it to say that the choice was in part accidental and in part due to the structural conditions faced by the leaders of each country. One such structural difference was the role of ethnic nationalities in each of the countries. Economic centralization in the former Soviet Union was used to contain ethnic nationalism whereas in China such concerns were much weaker.

${ }^{14}$ The provinces also include four provincial-level municipalities, Beijing, Shanghai, Tianjin and Chongqing. In the 1970s, there were twenty-nine provinces. In 1987, Hainan, formerly under Guangdong province, was elevated to a provincial status and in 1998, Chongqing, located in Sichuan province, became a municipality with the provincial status.
} 
differences in tax rates, the average coefficient of variation value for twenty provinces was 0.193 in 1986 but 0.657 in 1990. Based on this evidence, the World Bank draws the following conclusion, "The overall finding is that there is no evidence to support a convergence of returns to capital across different provinces. Other things being equal, this suggests that capital mobility has not increased noticeably since 1985. 15 There is direct and strong evidence on declining inter-provincial trade. For example, the percentage of total consumer imports originating from other provinces declined from 38 percent in 1979 to 29 percent in 1986. In some provinces, this reduction has been quite drastic. Inner Mongolia imported 100 percent of its consumer goods in 1979 , but only 22 percent in 1986.

Capital market is similarly fragmented and getting more so over time. Two researchers, Shaoguang Wang and Angang Hu, showed that net exports as ratios of provincial GDP declined uniformly across all Chinese provinces in the 1980s and 1990s. ${ }^{11}$ Net exports are the differences between savings and investments in a province. When a province saves more than it invests, its net exports are positive, i.e., it is exporting capital to other provinces (or to the central government). When a province invests more than it saves, it is importing capital in order to finance the portion of its capital requirements it cannot fund on itself own. What the two researchers showed is that provinces with a large positive net export position in the late 1970s (such as Beijing, Tianjin, and Shanghai) ended up with a significantly smaller positive net export position in the early 1990s. On the other hand, provinces which received large capital from other provinces in the late 1970s received far less in the early 1990s. Although this measure is imprecise, it can serve as a rough indicator of the extent of the barriers to inter-provincial capital mobility. $\frac{18}{18}$

15 (World Bank 1994, p. 54).

${ }^{16}$ (World Bank 1990).

${ }^{17}$ (Wang and Hu 1999).

${ }^{18}$ The imprecision arises from two main sources. First, Wang and Hu did not net out the portion of capital export to the central government. This weakens their claim that there was substantial inter-provincial capital movement before the reform. There might be substantial movement of capital across provinces before the reform but it was effected by central planning. Second, Wang and $\mathrm{Hu}$ did not net out foreign investment in their data. The problem here is that since many of the rich and coastal provinces began to receive FDI in the early 1990s their net export can decline not because they export less capital to other provinces but because they receive more FDI. Import of FDI is a negatively-signed debit item in the GDP accounting framework and mathematically it would reduce the size of the positive net exports. This 
That China's marketplace is fragmented or that it has become more fragmented over time is not a new revelation to students of Chinese economy; what may be less familiar is the striking extent of fragmentation of the Chinese economy. There are a number of ways to show how fragmented Chinese economy is. First, as I have already alluded to, China's political system is remarkably centralized and unified compared to many of the political systems presiding over large countries. Political unification is often thought of as facilitating economic unification as trades in goods, services and assets are transacted under common or at least similar regulatory and legal frameworks and standards. Political integration is also supposed to reduce transaction costs of trade by creating a common currency area and allowing freedom to travel across different regions. It is thus unusual for a country to have such a high degree of political centralization coupled with a remarkable degree of market segmentation. The aforementioned World Bank report makes the following comment, "In China today, there is an anomalous situation where major elements of economic union including a single currency and a common external tariff are combined with a lack of some basic features of a free trade area., 19

Second, China's market fragmentation is remarkable considering the extent Chinese economy is integrated to the rest of the world. For some reason, Chinese have increasingly preferred to trade with foreigners to trading among themselves. In 1992, the average domestic trade/GDP ratio for twenty-six provinces for which data are available was 14.7 percent, but in the same year, the average foreign trade/GDP ratio was 17.5 percent. This foreign bias is new and it did not result from historical patterns. In 1985, the average provincial domestic trade/GDP ratio was 25.1 percent, compared to 14.2 percent for the foreign trade/GDP ratio. Between 1985 and 1992, of twenty-five provinces whose data are available in the World Bank report, twenty-two of them experienced a decline in domestic trade/GDP ratio; some, dramatically. Tianjin, for example, started with a domestic trade/GDP ratio of 90.2 percent in 1985 but ended with 14.2 percent in 1992, a decline of 76 percent. Heilongjiang, Shanghai, Anhui, Fujian, Henan, Guangdong, Guangxi, Gansu, and Ningxia all experienced a double-digit reduction in the domestic trade/GDP ratio. In contrast, of the twenty-seven provinces for which there are available data, foreign trade/GDP ratio rose in twenty-six of them. The sole exception was Hebei province, whose ratio declined by 1.4 percent.

statistical bias is especially severe because provinces that would normally export capital to other provinces receive most of the FDI.

${ }^{19}$ (World Bank 1994, p. 7). 
Thus over time, Chinese provinces increasingly trade less with each other while at the same time increasing their economic integration to the outside world at a rapid pace. The declining inter-provincial trade, coupled with a growing external trade orientation, suggests that Chinese market may be less unified as compared to similarly-sized markets elsewhere. For example, trade among members of European Community (EC) amounted to 28.3 percent of EC's GDP in 1989. This is higher than the ratio for the average inter-provincial trade to GDP ratio in China (14.7 percent) in 1992. In 1990, trade among the republics of the former Soviet Union was 27.2 percent of GDP, excluding the largely self-sufficient Russian republic. When the data for the Russian republic are included, the Soviet inter-republican trade to GDP ratio was still higher, at 17.3 percent. 20

To appreciate the anomaly of the Chinese situation, it is noteworthy that the normal trading patterns exhibit precisely the opposite kind of bias. Trade, as economists have documented, is a home-bound activity, i.e., domestic residents tend to buy from each other more than they do from foreigners. A convincing illustration of the natural home bias in trade is a comparison of domestic trade among Canadian provinces with trade volume between Canada and the United States. This is a good test of the home bias in trade because Canada and the United States share many characteristics and the kind of differences that normally deter trade along cultural and political lines should not be noticeably pronounced between these two countries as among Canadian provinces. Yet Canadians trade with each other far more than they do with their American neighbor. As of 1988, inter-provincial trade in Canada, for example, was about 20 times its trade with the 30 states in the United States - the states Canadian provinces traded with most intensively. 21

Third, China is widely perceived as a controlled and closed economy. (Sachs and Warner 1995) classified China as a "closed economy", using their three criteria all focusing on external policy measures (tariff and non-tariff barriers to trade and black-market premium for foreign exchange as an indication of distortions of foreign exchange allocation). Foreign investors also frequently complain about bureaucratic and legal barriers and difficulties of doing business in China. However, this widely-shared perception of China as a closed economy is simply incongruous with many facts of the Chinese economy. For one thing, as I have pointed out in Chapter 1, FDI/capital formation ratio for China was already inordinately high as compared to

\footnotetext{
${ }^{20}$ All these data are found in (World Bank 1994), pp. 37-43.

${ }^{21}$ The finding was reported in (McCallum 1995), as quoted in (Ghemawat 2000).
} 
many countries that are on the "open economy" list as devised by Sachs and Warner. Another anomaly is that investors from foreign countries seem to have found China a much more hospitable place than investors from "foreign provinces." As I have documented in Chapter 1, foreign investment, as measured by shares of capital formation, is often several multiples of similarly-measured other provincial investments for some provinces (such as Guangdong, Liaoning and Beijing) or is roughly equal in size for other provinces (such as Shaanxi and Sichuan). Only in Shanghai, does one find investment from other provinces significantly exceed foreign investment. 2 .

\section{Regional import substitution strategies}

Economic fragmentation is not just a function of geography but also of policy and institutional choices. Arguably, the policy factors have been more important in creating the kind of internal trade patterns that have been presented so far than the natural factors such as geography. China is a large country and its mountainous and treacherous expanse imposes high transport costs on trade among Chinese regions. Geographic distance, as demonstrated in the socalled "gravity" models of trade, affects patterns of trade. But in the case of China, something more than geographic distance is at play. While high transport costs may induce an initially low level of internal trade, they do not explain why internal trade has declined over time and why it has declined during a period in which massive investments were made in China's transport infrastructure. ${ }^{23}$ A more important driver of economic fragmentation results from what I term as "regional import substitution strategies," which have sharply reduced cross-regional mobility of capital and goods. Regional import substitution strategies, just as import substitution strategies at

\footnotetext{
${ }^{22}$ See Table 2.6, (World Bank 1994). Two caveats are in order for Shanghai data. One is that
} central government invested heavily in Shanghai during the period for which data are available (i.e., late 1980s and early 1990s). Thus it is possible that investments from other provinces in fact incorporated centrally-organized investment programs. Second, because the data series end in 1992, it is possible that the magnitude of foreign investment is under-estimated. Shanghai began to receive a large flow of FDI beginning in 1992.

\footnotetext{
${ }^{23}$ During the 1980s and 1990s, China has made major strides in its infrastructural developments.
} The railways increased from 40,990 kilometers in 1980 to 56,700 kilometers in 1998. The bigger increases occurred in roads and airline travel routes. Roads increased from 88,000 kilometers in 1980 to 127,850 kilometers. Civil aviation routes registered the greatest increases, from 19,530 kilometers to 150,580 kilometers. See (State Statistical Bureau 1999). 
the national level, aim to develop import-replacing infant industries at home by relying upon a combination of trade restrictions and of imposing restrictions on capital export. Over time, a fragmented and undersized industrial structure emerged as the economic reforms have placed more regulatory responsibilities, ownership of firms, policy and financial resources in the hands of regional governments.

There are many anecdotal accounts of active anti-trade policies adopted by regional governments which are consistent with the aforementioned data showing declining internal trade over time. What is remarkable is that these trade restraints against goods from other parts of the same country are quite similar to trade protectionist policies adopted by politically sovereign nations and indeed, in some of the areas, the trade restraining policies have even gone beyond trade protectionism at the national level. According to a detailed study on this topic by (Wedeman 2000), provincial governments resorted to alright import bans, enforcing discriminatory product and health certification standards, imposition of tariffs--in the form of fines for importing goods from foreign provinces--and dumping charges, confiscation of profits earned on marketing foreign-provincial goods, subsidies to local commercial units for buying locally-produced products, etc. A number of counties in Hubei province went a step further: They issued their own currencies in order to prevent their residents from purchasing goods in the neighboring Hunan province. 24

Regional governments curtailed both imports from and exports to foreign provinces, although the emphasis on import and export curtailment would vary depending on the economic cycles. During an expansionary phase of a business cycle when supply became taut, local governments attempted to reduce outflows of natural resources and raw materials to other regions. In the 1980s, there were several rounds of inter-provincial trade conflicts involving export of raw materials and natural resources. In the annals of Chinese economic history, these episodes are known as cotton wars, silkworm cocoon wars and tobacco wars. 5 Import controls were imposed on manufactured goods and were more frequent when the market experienced a glut, as during much of the 1990s. Local governments resorted to a beggar-thy-neighbor tactic to deal with a recession by curtailing competition with home-province products and by protecting local markets. China experienced a particularly strong bout of import protectionism during the austerity period of 1989-1991 as regional governments, laboring under a recessionary effect of

\footnotetext{
${ }^{24}$ (Wedeman 2000), p. 227.

${ }^{25}$ See (Watson 1989 ) and (Guo Wanqing 1992).
} 
monetary tightening, resorted to various and extreme measures to protect local markets. In recent years, trade protectionism eased somewhat. Since 1995, Chinese economy has turned from a shortage economy into one characterized by overcapacity and a buyer's market. In addition, the central government also liberalized a considerable number of prices of raw materials and energy. The reduction of the previously huge mark-ups has dampened the impetus for developing manufacturing capabilities locally. This has apparently boosted interregional trade, although the economic evidence on this effect is not overwhelming.

The most immediate effect of regional import substitution strategies is emergence of an economic structure that is "repetitive and duplicative." Regions do not specialize along the lines of their comparative advantage. Instead they all push strongly into similar industries and product groups, resulting in a convergence of industrial production across different regions. The convergence of production is sharpest in manufacturing industries. (Young 1997) presents evidence that while shares of manufacturing and construction industries in provincial output varied between 34 percent and 77 percent in 1978, by 1995, the range of variations was reduced to between 36 percent and 57 percent. (World Bank 1994), looking at eight principal groups of industries (coal mining, tobacco, textiles, chemicals, building materials, machinery, and electronics and telecommunication), found that their representation in all the provinces. Also variations of number of firms and total employment are also low, considering the diversity of the provinces in terms of their size and endowment of natural resources. To put Chinese industrial convergence in perspective, as of the early 1990s, there were seventy-six firms producing TVs with 113 assembly lines scattered around the country and as of mid-1990s, there were over 120 vehicle assembly firms in every province except two remote provinces (Tibet and Qinghuai), exceeding the total number of motor vehicle producers in the world. This industrial dispersion violates the usual economic logic that predicts firms to be typically clustered together regionally in order to reap the benefits of agglomeration economies.

The convergence of industrial production results directly from forward and backward integration activities engaged in by the regional governments. The integration incentive lies in the arbitrary pricing decisions made by China's central planners. Historically, central planners have priced raw materials and upstream goods low while keeping prices of final goods high, creating huge profit margins in the final goods sector. ${ }^{26}$ According to the World Bank, as of the

\footnotetext{
${ }^{26}$ The reason for such a pricing decision is unclear. (Wong 1992 ) argues that the price wedge is designed so that central planners can extract surpluses to finance industry. This is a strange motive, as
} 
1980 s, the price of heavy fuel oil is one-third that of the international level and coal is set at 60 percent of its long-run marginal production costs (World Bank 1985: 71). As regional governments have gained more policy and financial resources, they are more able to pursue activities to capture the rent inherent in the large price distortions. Provinces with comparative advantages in natural resources and raw materials integrated forward to set up manufacturing operations in order to capture the rents created by the price mark-ups (called price scissors in the central planning parlance). Provinces with comparative advantages in downstream stages of production respond by integrating upward. Between 1979 and 1984, Yunnan and Hunan, two tobacco-producing provinces, rose by 3 percentage points in terms of their national shares of cigarette production, while two traditional cigarette-making provinces, Shanghai and Shandong, declined by 3 and 2.4 percentage points, respectively. In the case of natural resources, provinces resort to importing the needed inputs abroad. In the 1980s, Zhejiang and Jiangsu, China's traditional suppliers of raw silk located next door to Shanghai, kept raw silk to themselves rather than "exporting" to Shanghai. In 1988, Shanghai received 40 tons out of 2,000 tons of raw silk allocated to it and Shanghai had to use its precious foreign exchange to procure raw silk abroad despite the fact that China was the world's largest producer and exporter of raw silk.

\section{Institutional sources of economic fragmentation}

Even if price distortions create rental opportunities, they do not necessarily lead to the enactment of regional import substitution strategies documented above. Regional governments must be sure that the benefits of pursuing regional import substitution accrue to them, not to the central government. How rental income is divided between the central government and regional governments is a function of an institutional design. Under China's current institutional

(Young 1997) pointed out. Since everything is arbitrary under central planning, the planners could just have set raw materials' prices high and final goods' prices low to accomplish the same goal. The more plausible reason is ideological. According to Marxist theory of value, raw materials do not acquire value until and unless they have been processed by labor inputs. Final goods would then have fetched higher prices than otherwise would be the case to compensate for the zero or artificially low costs imputed to raw materials and upstream goods.

27 (World Bank 1990).

${ }^{28}$ China accounted for 60 percent of world production of raw silk and 90 percent of world export. This account is given in (Young 1997). 
arrangements, claims over financial flows are apportioned between the central government and regional governments according to an administrative principle. China's tax system defines tax base not by the residency of the firm but by the level of governmental administration. Broadly speaking, income tax revenues generated by the regionally-owned and operated enterprises accrue to the regional governments whereas income tax revenues generated by enterprises owned and operated by the central government accrue to the central government. 9

The Chinese economic system classifies enterprises according to their level of administrative supervision. An enterprise is categorized as a "central enterprise" (zhongyang qiye) if the control rights-managerial appointments, asset disposals, strategic directions of firms - and some or all of the income rights reside with the central government in Beijing. A regional enterprise (difang qiye), as the name suggests, is such that the same control and income rights belong to a regional government. Regional enterprises can be further divided into provincial enterprises (shengshu qiye) or city or county enterprises (shishu or xianshu qiye). In 1995, according to the Third Industry Census, there were 87,905 industrial SOEs, of which 83,167 were owned by the regional governments. The regionally-owned SOEs accounted for 65 percent of the total SOE assets and 64 percent of sales. Among the regionally-owned SOEs, most of the firms are controlled by the county-level governments. County governments controlled

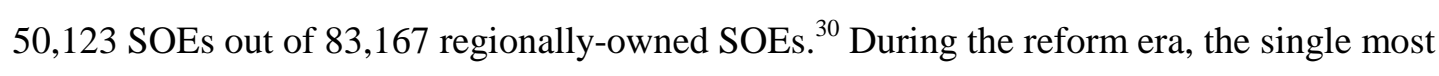
important development that affected tax divisions between the central government and regional governments was the delegation of control rights to regional governments, thus increasing the tax base of the regional governments. During the 1986-1990 period, the central government directly collected 33 percent of consolidated tax revenue; by 1993, the central share declined to 22 percent. The 1994 tax reforms, which created a federalist tax structure, restored some of the fiscal control by the center. In 1997, the central share rose to 49 percent. On the expenditure side, however, regional governments have remained dominant. In 1997, they accounted for 71 percent of the consolidated expenditure, roughly the same share before the 1994 tax reforms.

${ }^{29}$ The 1994 tax reforms, for the first time, sought to alter the foundation of this tax-sharing principle. The gist of the reforms was to institute a federalist tax system in which central and regional authorities operate their own tax collection apparatuses and the tax base was no longer defined administratively but by different tax categories. Despite the fact that the principle of tax federalism guided much of the 1994 tax reforms, a number of analysts commented that the actual tax collection practices still bear some of the remnant of the old system.

${ }^{30}$ The data are from the 1995 industrial census. See (Office of Third Industrial Census 1997). 
The dominant view in the studies of Chinese economy attributes the rise of local protectionism and developmental incentives favoring local infant industries to this system of tax divisions and to the economic reforms that assigned greater fiscal flows and economic control to regional governments. The forward integration and export restraints on raw materials, whose prices were artificially depressed, essentially channeled resources into regional tax base and constituted activities by regional authorities to maximize their tax revenues. During reform era, according to this interpretation, as regional authorities gained more fiscal and economic controls, local protectionism and development of local infant industries gathered momentum. The prescription to remedy the "fragmentation problem" in the Chinese economy often advocates a recentralization of financial resources and economic and managerial functions in the hands of the central government.

This analysis blaming "excessive" decentralization provides only an incomplete explanation. For one thing, despite the widely-acknowledged fragmentation effect of this way of administering the tax collection and assigning control and income rights of SOEs, the system enjoys a remarkable resiliency. The administrative tax divisions and dividing controls of firms by levels of government have a long history in China. Although there have been many revisions and modifications, the broad principle of administrative tax divisions was laid out in the early 1950s, rather than during the reform era. The genesis of the system was a circular which the State Council issued in March 1951 entitled, "The Decision to Establish a Tax Division System for 1951." This was a milestone in the history of China's tax system as the basic principle of the administrative definition of tax base was enshrined in this document. The circular created a three-tier system of budgetary administration — central government, large administrative regions, and provinces - and defined the tax base of each level of the government as constituting those firms being administered by a particular level of government. Initially, lower-level governments, such as provinces, only administered a few firms and thus commanded only a small tax base but over time, their tax base expanded as more and more firms were assigned to their control. During the reform era since the early 1980s, a second round of fiscal delegation took place, which divided the tax base of a regional government—say a province-into several and relatively independent tax bases. Thus municipal enterprises paid taxes going into municipal coffers and county enterprises paid taxes going into county coffers. But the fundamental principle of defining tax base administratively predated economic reforms by almost three decades.

Nor is local control of SOEs a new development unique to the reform era. In fact, prior to the advent of reforms, Chinese economy was already quite decentralized. As a number of 
commentators noted, China was never a centrally planned economy after the image of the Soviet model. It was more of a regionally planned economy. 1. Despite many of the similarities in their economic systems during what Kornai calls "the classical stage of socialism," there were some sharp differences between the Soviet and Chinese systems. In general, the Chinese system was much less decentralized as compared with the Soviet system even at the height of central planning in the mid-1960s. For example, the Chinese State Planning Commission allocated just over 500 product categories compared to some 50,000 products allocated by the Soviet central

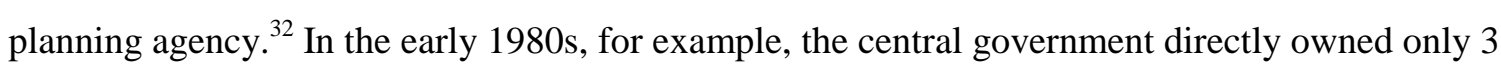
percent of the 83,000 enterprises (Wong 1985 ) and, in terms of industrial output, SOEs subordinate to the central ministries only accounted for 9 percent of total industrial output for the state sector (He Jianzhang and Wang Jiye 1984). ${ }_{3.3}$ The tax derivation as a function of administrative supervision of firms is a long-standing and well-entrenched principle in the Chinese economic system. In an interesting case in 1980, when the central government attempted to transfer some of the firms to central control, the central government agreed that the original "owners"-in this case provincial governments-would still claim 20 percent of the income-tax revenue generated by enterprises previously under their supervision. 34

What the conventional analysis ignores is that this decentralized tax and SOE administration is inherently rational in the context of state ownership of firms. Fundamentally, assigning more control and income rights of SOEs to lower-level governments is one of the few available tools to improve efficiency in a socialist economy. State ownership of assets means that the government is the rightful owner and thus it is entitled to the exercise of many ownership

${ }^{31}$ See (Donnithorne 1981 ) and (Qian and Xu 1993).

${ }^{32}$ I have compared Chinese and Soviet central planning elsewhere in greater detail. See (Huang $1994)$.

${ }^{33}$ In the 1980s there were both centralizing and decentralizing shifts. Between 1982 and 1987, the Center established three nationwide corporations for the petrochemical industry, the automobile industry, and for the nonferrous metals industry and in the process re-centralized enterprises in these three sectors. On the other hand, enterprises in machine-building, electronics, textiles, and metallurgy were given over to local governments. The net impact was a moderate increase in the share of central industrial output; in 1985, the central government accounted for some 25 percent of industrial output (State Council and State Planning Commission 1990).

${ }^{34}$ For more in-depth analyses of the evolution of China's tax system, see (Wu Deming 1987), (Lardy 1978 ), (Wong 1991 ), and (Wong, Heady et al. 1995). 
rights such as choosing managers, transferring and disposing of assets, and deciding on the general strategic directions of the firm. But in exercising these rights, a bureaucracy runs into a perennial problem: It simply does not have the requisite information in right quantity and quality to exercise these rights wisely. As (Hayek 1974 ) famously argues, most of economic information is inherently complex. Consumer preferences are atomistic and unique to "circumstances of place and time" and, above all, are ever-changing. On the production side, the same problem arises from the heterogeneity of products and production processes. A central bureaucracy is inherently handicapped to collect and process this type of information in a timely manner. A local bureaucracy, while not necessarily up to the task completely, at least is better able to respond more quickly to the ever changing and varied economic exigencies. This is so because bureaucracy is not only unable to collect the sufficient amount of information, it also loses the information it does collect. Because information goes through many administrative layers in a bureaucracy, information that has been collected get lost, as (Lindbeck 1971 ) points out.

The informational requirements of managing economic affairs from Beijing are nothing short of mind-boggling. In the 1980s, routinely each year, between 10,000 and 30,000 new investment projects broke ground. Given the large number of investment projects at any given point in time, it is simply administratively impossible for the central government to review each project carefully and to follow the project cycles at each step of the project life. Indeed, even the provincial officials feel that they do not have sufficient information and staff resources to evaluate investment projects at the prefectural and county levels, which prompted them in 1984 to request a further delegation of review authority. 5 In 1997, there were over 110,000 industrial SOEs alone. The informational requirements of running these numerous firms are simply beyond the capacity of a single bureaucracy. As long as the Chinese state insists on retaining the control rights over these firms in the hands of the government, the enormous managerial and administrative complexities leave no choice but to partition control rights among different branches or levels of bureaucracy. Decentralization of income rights, in many ways, serves the same purpose of alleviating the intrinsic complexities of running a socialist economy.

Fundamentally, it is an incentive device to ensure that regional governments put their resources to create value as the system allows them to retain a portion of the value creation. The effect of this system is to ease the need for the central government to constantly monitor and supervise the

\footnotetext{
${ }^{35}$ For a more detailed illustration of this informational problem in managing investment projects from the Center, see (Huang 1996).
} 
actions of the regional governments. Given the inordinately high informational requirements of running a socialist economy, administrative delegation of tax collection and firm management is an efficiency-improving tool and is thus "rational" given these constraints. In other words, economic fragmentation is a costly by-product of a conscious decision by the state to preserve socialism while searching for a way to minimize the high informational costs of operating such an economic system.

The role of state ownership needs to be taken into account explicitly when considering the effect of decentralization on rent-seeking motives and behavior on the part of regional governments. China's decentralization attempt is of an administrative kind: It moved managerial responsibilities and financial resources from a higher level of bureaucracy to a lower level bureaucracy. It is not an economic decentralization, which moved the same responsibilities and resources out of the sphere of government and into the hands of private entities and entrepreneurs. The absence of an economic decentralization also explains another anomalyChina's decentralization so far has enhanced profit incentives but not self-reinforcing cost constraints. Building up local infant industries costs a lot of money and a cost-constrained investor would maximize expected payoffs, not current payoffs. Expected payoffs are a function not just of one's own investments but investments by one's competitors. During the reform era, as many regional governments poured massive resources into virtually identical product lines (such as automobiles and electronics) the expected payoffs should be lower than the current payoffs. The reasoning is straightforward. The new facilities will come online and a greater supply of goods in temporary shortage will diminish the current profit margins. Normally this kind of competitive dynamics deters an investor sitting on the sideline, but for some reason, investments by competitor provinces do not exert such a deterrence effect in China. In the mid1990s, as the evidence of overcapacity in automobile and electronics production became abundantly clear, no less than twenty provinces targeted electronics industry for further development. Additional nineteen provinces declared that they would target automobile production for development. 36

In a typical centrally planned economy, there is a fundamental asymmetry in the incidence of costs and benefits associated with undertaking investment activities. Benefits-enhanced reputation and higher financial rewards--accrue to the bureaucratic shareholders and SOE managers; investment costs and costs of investment failures, on the other hand, are borne by

\footnotetext{
${ }^{36}$ See (Institute of Industrial Economy 1998).
} 
the society at large. (Kornai 1992 , p. 163) comments, "Expansion drive is a fact of life for the bureaucracy. And because this system has only bureaucrats and no real owners, there is an almost total lack of internal, self-imposed restraint that might resist this drive." Socialists firms are said to face "soft budget constraints," which refer to bureaucratic readiness to provide financial

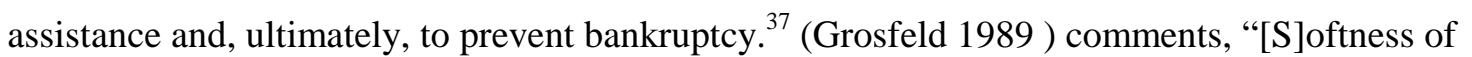
the budget means that there is no danger of a forced exit. Even if enterprises have to repay credits (which is not always necessary) insolvency is not a real threat; they can always rely on subsidies, price adjustment, tax facilities, and so on." Soft budget constraints, in essence, imply zero risks for the investment activities undertaken by SOEs and are an important reason why restraint on capital spending by SOEs is not self-enforcing. This affects investment calculus of regional officials strongly. They are positively biased toward the success of any investment project they launch and tend to systematically discount the risks that are entailed. Overinvestment is inevitable as a result of this dynamic.

Decentralization per se does not explain why economic fragmentation has gone to such an extreme extent in China. Given the high profit margins in the downward sectors, it is not surprising that regional governments are motivated to erect trade barriers against goods from foreign provinces. What is puzzling is the dramatic extent internal trade has been reduced by the actions of Chinese regional governments. Trade barriers aside, domestic borders are far more open or porous than international borders. One indication is the relative unfettered movement of people across Chinese provinces. The size of migrant and transient labor is huge, estimated

${ }^{37}$ For a classic illustration of soft-budget constraints, see (Kornai 1980 ).

${ }^{38}$ To be sure, one can cite similar examples of weak or absent self-enforcing restraints on investment activities in capitalistic economies but the important point is that typically, this type of behavior results from some degree of governmental bearing of investment costs. For example, the reckless lending behavior by the savings and loans institutions in the United States in the 1970s was in part, rooted in the fact that they were federally insured and thus they faced softer budget constraints. Similarly, Paul Krugman analyzed the moral hazard factors that led to the onset of financial crisis in Asia in 1997. In his model, because banks were insured by the government against credit default, borrowing firms were encouraged to pursue "Panglossian" value rather than a realistic prospect of profitability. The idea is that since firms did not bear the costs of failures they were positively biased toward project success and were willing to go ahead with a project even if the project only had a slim chance of being successful. 
around 100 million at a given point in time in the 1990s. ${ }^{39}$ Poor and labor-surplus provinces have developed active programs to export labor to labor-deficit regions. It is thus somewhat of an anomaly that such a large movement of people is not associated with large-scale arbitrage activities that may naturally arise to take advantage of the opportunities created by the apparent interregional price differentials.

A plausible answer to this apparent puzzle is that marketing channels and investment processes are still subject to far more stringent political controls by China's regional governments than the nascent and emerging labor market. One straightforward piece of evidence is the statist nature of China's distribution system. Although there has been some progress in reforming Chain's distribution system, it is important to point out that progress here is typically defined as a decline in the role of the state in allocating goods. It does not refer to the decline of the role of the state in distributing goods. This is a significant distinction. Sate allocation means that the state makes decisions about who gets what, rather than letting market make those decisions. Distribution is the process whereby goods go from the producer to the end-user. During the reform era, the total number of categories of consumer goods allocated through plan was 274; it was only fourteen in 1992. In value terms, goods subject to governmental allocation accounted for 90 percent of total goods in circulation in 1980; by 1992, it declined to 12 percent. 10

The state still retains a paramount role in distribution. The de-statization of marketing functions of the economy was more substantial in agriculture than in industry. In 1984, for example, the government, for the first time, permitted individual farmers to engage in longdistance transport of their produce, to use motor vehicles in trade and to purchase motor vehicles for transport. However, numerous restrictions were imposed at the same time. For example, farmer-traders needed to obtain separate permits for trading, vehicle and passes for crossjurisdictional transport. 1 Although these restrictions seemed exacting, liberalization in the urban areas was even more limited. Compared to industrial production, ownership diversification in the service sector--especially in wholesaling, retailing and banking--has not happened at all. In 1996, for example, while the SOEs only accounted for less than 40 percent of the output value in

\footnotetext{
${ }^{39}$ For a careful recent study on migration issues in China, see (Solinger 1999).

${ }^{40}$ See (World Bank 1994) p.69

${ }^{41}$ Detailed in [Wedeman 2000 \#2129] pp.46-47
} 
industry, service SOEs accounted for 54.2 percent of the retail sales and 66.8 percent of the wholesales. To put these numbers in perspective, in 1965 and 1978, SOEs accounted for the 53 percent and 53.5 percent of the retail sales. This is indeed remarkable. During the height of the centrally planned era, industrial production was completely monopolized by the SOEs while some leeway was allowed for non-state firms in the service sector. Twenty years of economic reforms have not attenuated the near state monopoly in distribution at all. ${ }^{22}$ Collective firms, many of whom are quasi- SOEs, accounted for the rest. In 1996, collective firms generated 29.8 percent of retail sales and 25.4 percent of wholesales. In foreign trade, the dominance of the SOEs is nearly absolute. In 1996, SOEs accounted for 89.9 percent of import business. Truly non-state firms, such as private firms and FIEs were simply non-consequential. In 1996, private firms accounted for 1.3 percent of the wholesale business and 2.77 percent of the retail sales. The inconsequential role of the private firms in the distributional sector, in part, reflects the detailed restrictions placed on private involvement. For example, only private natural personsprivate corporations-were granted trading permits. This severely restricts the extent of private involvement in China's distributional sector.

42 Two caveats need to be added to this statement. First, because marketing functions have been granted directly to firms themselves, it is conceivable that non-state production firms can engage in buying and selling activities without going through the state-controlled marketing channels. This change would not be reflected in the statistics cited in the text. It is quite possible that when direct marketing data are included, the non-state sector would appear to be more important simply because the production role of the SOEs has shrunk. But this is unrelated to reforms in the service sector per se and this is not inconsistent with the observation that service sectoral reforms have lagged behind. Second, the retail sales data for 1965 and 1978 include restaurant business whereas the 1996 data do not. Strictly speaking, the two sets of data are not comparable. Because one area of service sector that has witnessed an active involvement of private firms is the restaurant business, including restaurant business in our tabulation will distort our analysis, which is concerned with sales of goods. Obviously, the inclusion of the restaurant business data for 1965 and 1978 would exaggerate the extent of the SOEs dominating in goods transactions but the bias should be modest. As is well-known, in a centrally planned economy, restaurant business was under-developed and its value in the total retail sales was probably very small. The 1965 and 1978 data come from (World Bank 1994).

${ }^{43}$ Retail, wholesale and import data, broken down by ownership of the distributional units, are reported in (State Statistical Bureau 1997). 
The state ownership of the distributional units makes it more likely that service SOEs act as developmental tools on behest of regional governments. Indeed, anedoctal accounts suggest that a frequent protectionist tactic is restrictions imposed on the state-owned marketing institutions to import goods from other provinces. 14 The absence of genuine competition from profit-minded private firms in the service sector probably have prolonged the regionalized rental accumulation longer than it would have persisted otherwise. If the political control over marketing institutions had been less effectual, one would have observed substantial arbitrage activities between the protected provinces and foreign provinces. Price differentials among different provinces and supernormal profit margins between upstream and downstream production would have disappeared faster than they actually did. The fact that local protectionism persisted over the entire reform era and an apparent absence of sizable black market activities are evidence of the extent of the state controls over marketing channels. ${ }^{-5}$

\section{A case study of economic fragmentation: Automotive industry}

Probably, the best illustration of the extent of economic fragmentation in China is the country's automotive industry. Automotive industry is among the most scale-intensive industries. In industries characterized by scale economies, large firms enjoy cost advantages over smaller firms. Economy of scale means that there are increasing returns to scale within a large range of production volume, i.e., average costs fall when the volume of production increases.

${ }^{44}$ (Wedeman 2000) gave many such accounts.

${ }^{45}$ There were press reports about smuggling activities in raw materials, especially agricultural raw materials, such as cotton. But press accounts of smuggling activities in manufactured goods are surprisingly scant. This could result from greater controls by the state over marketing of manufactured goods.

Smuggling in raw materials, especially agriculturally-based raw materials, could be more frequent because of the greater relaxation on private trading in the agricultural sector.

${ }^{46}$ Throughout this chapter, economy of scale (EOS) refers to what is known as "internal economy of scale" in economics, i.e., economy of scale that arises at the plant level. EOS is also refers to economy of scale at the industry level and this is known as "external EOS." External EOS is used to explain why firms in certain industries are concentrated geographically, e.g., service firms in New York City, computer firms in Silicon Valley or automotive firms around Detroit. Even a casual examination of Chinese automotive industry shows the lack of external EOS. Automotive firms are highly dispersed and can be found in 28 out 
Commonly, economy of scale is measured in terms of minimum efficient scale (MES), i.e., the minimum absolute scale of production required for efficiency. For vehicle assembly, the MES is commonly given around 250,000 units at the plant level and for a single basic model type. ${ }^{47}$ The MES for other automotive products is similarly large. For example, for engines and transmissions, the estimates ranged between 250,000 units to one million units.

The exacting MES requirements for the automotive production often mean that automotive firms in developing economies are inefficient because they operate and service small markets. They incur significant "the economy of scale cost penalty" by operating below MES (Altshuler, Anderson et al. 1986: 39). China is an extreme example of an automotive industry plagued by scale diseconomies. In 1995, China produced 1.45 million motor vehicles. While this represents a ten fold increase in a span of seventeen years and China is now the world's eleventh largest producer of motor vehicles after Brazil, Chinese automotive industry is the most fragmented in the world. The 1.45 million volume was spread among some 122 assembly enterprises and many vehicular classifications and models, with an average volume about 12,000

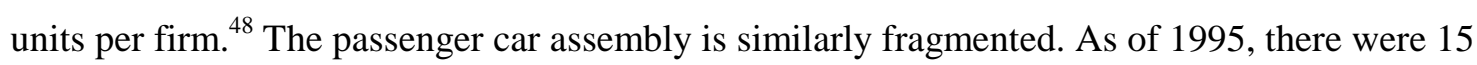
passenger car assembly firms with a total output of 326,000 units, averaging 21,726 units per firm. To drive these numbers home further, it is worth noting that the entire output volume of 122 assembly firms in China is smaller than the output level of one single Japanese firm in 1969, Toyota (1.45 million compared with 1.47 million units) and about the same level of Hyundai Motors in 1996, 1.3 million units (Schuman and Reitman 1997). The entire passenger car output volume of 15 assemblers in 1995 was about the same as that of Nissan in 1967 (352,045 units) and only a third of Toyota in 1969 (964,088 units).

of 30 provinces in China. Only two highly agricultural and barren provinces, Tibet and Qinghai, do not have their own automotive plants.

${ }^{47}$ Estimates vary among different experts but they all fall within 250,000 and 300,000 range. See . (Baranson 1969), (Pratten 1971), (Rhys 1972), and (White 1971).

${ }^{48}$ The 122 figure does not include those firms/plants that specialize in outfitting chassis to special purpose vehicles as well as those plants specializing in components production. As of 1995, there were 536 such outfitting outlets and 55 engine and 1638 components plants.

${ }^{49}$ In 1995, China's entire output volume of truck production was roughly comparable to the volume of the largest Japanese automotive makers in the late 1960s. China produced 571,751 units of trucks, as compared with 442,621 for Nissan and 492,196 for Toyota in 1969. 
Even when the lowest estimates are used, it is clear that the Chinese automotive industry operates far below the MES across the entire spectrum of the automotive production. In 1995, the top producer of automotive engines churned out a volume of 177,000 units, as compared with the MES ranging from 250,000 to 1 million. The output of the largest producer of medium-duty trucks was 125,000 units while the number one car manufacturer, Shanghai Volkswagen (SVW), had an output volume of 160,000 after years of hovering below 100,000 units. Since 1996, SVW significantly expanded its production. In 1998, its output volume reached 235,000 units, far larger than FAW, which produced 168,351 units.

Because automotive industry is scale-intensive, the miniturization of automotive production must be rooted in China-specific factors rather than in the industry dynamics. One way to illustrate this point is to compare China with other countries. The idea here is that underlying economic factors tend to drive concentration ratios to similar levels across different countries. Many economic studies have indeed found that concentration ratios in market economies are rooted in production technology, scale economies and the use of the product rather than in the country-specific factors. Thus same industries tend to exhibit similar concentration ratios across countries and to the extent concentration ratios within the same industry differ the cause lies in the country-specific factors.

Table 1

Table 1 compares China with Brazil, Japan and Korea during the 1960s, 1970s and 1980s. These countries, like China in the 1990s, attempted to enter the automotive sector dominated by the large incumbent players. Two clear contrasts are evident. One is that as measured by one to three-firm ratios, Chinese automotive industry is far more fragmented both at the beginning and at the end of the period for comparison. In 1985, the one-firm ratio was 19.2 percent in China, as compared with 24.8 percent in Brazil (1959), 32.1 percent in Japan (1960), and 54.6 percent in Korea (1960). The second contrast is the trend. Among all three benchmark countries the automotive industry became more concentrated over time; in China, however, over time, the automotive industry became less concentrated. In 1985, for example, the three-firm ratio was 43 percent in China but it declined to 33.3 percent in 1995 and 37.8 percent in 1996. In the 1990s, the concentration ratios stayed at a low and stable level despite the government's effort in 1994 to streamline the industry. Only in the most recent years (1997 and 1998), the declining trends in concentration ratios were arrested somewhat. Apart from production

\footnotetext{
${ }^{50}$ The classic analysis along this line is (Pryor 1972).
} 
technology, market size also drives industrial structure. A larger market size can support a larger number of firms than a smaller market size. The last column of Table 1 shows that the market size for Chinese automotive makers in the 1990s - between 1 and 1.6 million--is only a fraction of Japan's market size (6.94 million) and is only moderately larger than Korea's market size (0.97 million) during the comparable periods. Thus China's far lower and decreasing concentration ratios are even more glaring on top of a relatively small market.

Asset market fragmentation is indicated by the sizeable differences on returns on assets (ROAs) across different regions and their persistence over time. ROAs are calculated for the passenger car segment of China's automobile industry, for two years, 1993 and 1995. Financial returns are given as the pre-tax profits and assets are the sum of net fixed asset stock and the working capital. For 1993, for the 15 firms in the passenger car segment, the coefficient of variation for their ROAs is 2.26; in 1995, it is 2.22 . The ROAs ranged from -0.11 to 0.56 in 1993 and from -0.17 to 0.648 in 1995 . The increasing competition on the product apparently has not equalized returns on assets.

\section{Creating a regional supply base: The case of SAIC}

In this section, I undertake a case study of Shanghai Automotive Industry Corporation (SAIC) to illustrate the dynamics whereby fragmentation in this scale-intensive industry occurs. $\underline{51}$ SAIC is China's second largest automotive producer in China. In 1998, it had more than 40 billion yuan in assets, compared to 64.9 billion yuan of First Automotive Work (FAW), China's largest and the first automotive producer. Measured in sales, however, SAIC is larger. In 1998, SAIC generated 39.5 billion yuan in revenues while FAW generated 36.8 billion yuan. Its star product, Santana, accounts for 50 percent of passenger cars sold in China annually and in 1998 SAIC launched the Buick manufacturing operation via a US\$1.5 billion joint venture with GM, which promised to put SAIC on the world's technological frontier in automotive manufacturing. For years, the Ministry of Foreign Trade and Economic Cooperation consistently ranked SAIC's

\footnotetext{
${ }^{51}$ The sustained effort on the part SAIC to develop in-house capabilities in components production
} is documented by a number of researchers. A thorough and careful study by Eric Thun documents a high level of political and policy commitment on the part of Shanghai government to transform the automotive industry into a pillar industry in Shanghai. This section of the chapter draws from his work as well as other sources cited in the book. 
flagship affiliate, Shanghai Volkswagen (SVW), as the number one among the top 500 FIEs in China on the basis of annual sales.

But as recently as 1990, SAIC was one of the several automotive firms trying to get into China's fast growing market for passenger cars. In Beijing, it faced competition from Beijing Automotive Industry Corporation (BAIC), whose flagship affiliate, Beijing Jeep Corporation (BJC), produced a popular sports-utility vehicle, Cherokee. BJC was a joint venture between BAIC and Chrysler. In the south, it faced competition from Guangzhou Peugeot, which manufactured a mid-sized sedan. SAIC was also behind in product quality. In a 1988 comprehensive quality inspection, one of its car models, SH760A, received only a passing score of 83.63 (out of 100). It was rated down particularly in its reliability category, receiving 14 out of 20 points in this department. BJC received a score of 90.11 while the Chinese parent of Guangzhou Peugeot, Guangzhou Automotive Work, received a score of 90.25 .53 The quality of a vehicle can be directly measured by its failure rate and the standard measure used in the industry is MTBF (miles traveled between failures). For the Shanghai car, the MTBF was 1,250 km,; for BJC, it was 2,500 km. 64 By 1996, however, SAIC had defeated its rivals. Its Santana subsidiary, Shanghai Volkswagen (SVW), generated a sales revenue roughly four times of BJC and Guangzhou Peugeot combined.

Table 2 summarizes the sharply divergent developments of SAIC and BAIC during the course of the 1990s. As recently 1990s, the two firms were roughly comparable in size and their performance. BAIC was larger in size as measured by sales revenue but a bit smaller as measured by assets. Its gross margins were lower, at 7.11 percent, as compared with 9.57 percent for SAIC but the difference was by no means large. In fact, BAIC seemed to possess some modest advantages in the composition of its workforce. As measured by the share of technicians of the workforce, the ratio for BAIC was 25.9 whereas for SAIC, it was 14.7. By 1997, the two firms

\footnotetext{
52 Sun Hong, "Shanghai Volkswagen: No. 1 of overseas funded," China Daily, November 2, 1996.

${ }^{53}$ Guangzhou Automotive Work was later renamed Guangzhou Automotive Industry Corporation.

54 The Guangzhou vehicle had the same MTBF as the Shanghai car but it was considerably better in another quality dimension: The mileage traveled before the first failure. For Guangzhou car, it was 1,469.5 km; for the Shanghai car, it was only $386.5 \mathrm{~km}$. To illustrate how shoddy the Shanghai car was, $386.5 \mathrm{~km}$ (242 miles) is roughly the distance between Boston and New York city. Thus a brand new car manufactured by SAIC in 1988 would experience its first failure by making a one-way trip from Boston to New York. The data from the 1988 comprehensive quality inspection are given in (Ministry of Machinery Industry 1991).
} 
have grown apart. SAIC is now dominant over BAIC in every conceivable dimension. It is several multiples of the size of BAIC, as measured by both sales revenue and assets. Its sales revenue was 4.5 times that of BAIC and its assets, 3.11 times. Its share of technical personnel in the workforce has grown whereas for BAIC it shrank. Profitability difference between the two firms grew apart significantly. SAIC was able to grow its gross margins further from its already healthy starting position in 1990, from 9.57 to 13.73 , but during the same period, BAIC was losing money.

Table 2

Two developments accompanied the rise of SAIC to the industry leadership position. First, it relied heavily on the financing and technological capabilities of the MNCs. Second, since the mid-1980s, it has pursued an aggressive strategy of creating a components supply base in Shanghai by engaging in an expensive and systematic backward integration. The next section of this chapter will link these two developments together by arguing that the strategy of creating a supply base in Shanghai deepened SAIC's dependency on FDI. For now, let me focus on and describe the effort by SAIC to create a supply base in Shanghai.

SAIC's strategy to create a supplier base in Shanghai, mainly to supply automotive components to its flagship affiliate, SVW, was extremely successful. (Success here is defined as the construction of a supply base that was previously not there.) In 1990, Shanghai was not a center of automotive components manufacturing. Its automotive output value only accounted for 7 percent of the national total as compared with 11.2 percent by Beijing and 9 percent by Sichuan (--a traditional components manufacturing base because of presence of many military plants). Measured in sales terms, Shanghai also lagged behind Beijing. It accounted for 8 percent of the sales revenue in automotive components as compared with 12.3 percent for Beijing. By 1996, their roles reversed with each other. Shanghai accounted for 20 percent of the output value in automotive components manufacturing, 14.2 percent of the net fixed assets and 22.2 percent of the sales revenue. For Beijing, however, the shares declined to 4.32 percent in output value; 5.44 percent in net fixed assets and 4.74 percent in terms of sales revenue.

The rise in Shanghai's importance in components manufacturing resulted from a shift in SAIC's sourcing patterns. First, SAIC increasingly produced inhouse what it had previously sourced from outside. By value, as of 1990, outsourcing constituted 65 percent of the Santana components that were produced in China. Over time, this share was to decline, contrary to the worldwide trend of increasing components outsourcing in the automotive industry. In 1997, Santana's domestic content rate reached 92.7 percent. Of this 92.7 percent, between 88 to 90 
percent by value was produced within Shanghai and of the amount supplied in Shanghai, 50 percent of them came from firms within SAIC group. By 1997, the outsourcing share was 50 percent by value, meaning that of those components sourced domestically, 50 percent came from firms not under the SAIC's organizational umbrella. Second, there was a geographic shift in sourcing patterns, i.e., SAIC increasingly bought components from firms located in Shanghai. In 1997, SVW's supply network consists of 248 firms, of which 40 are affiliate firms under SAIC and 158 are located in Shanghai. Although fewer in number, these 40 firms supply 50 percent of the components by value, suggesting that they are capturing the high-end spectrum of the components. ${ }_{5.5}^{5}$ This pattern of "regional sourcing" contrasts with other vehicle producers in China. BJC, for example, sources about 20 to 30 percent of its components locally; Guangzhou Peugeot, about 20 percent.

SAIC's regionalization drive was methodical and well-organized. To SAIC, regionalization entailed a simple objective: It was to replace imports not only from foreign countries but also from foreign provinces in China. Thus a product from France was treated exactly the same as a product from Changchun in Jilin province and the objective was to replace it with a similar product in Shanghai. Cost was not an issue; what mattered was the physical availability in Shanghai. In 1987, SAIC, with the full backing from the Shanghai municipal government, began a concerted effort to create supply capabilities in Shanghai. 6 The extraordinarily high margins of Santana sustained the SVW operation. In the late 1980s, the production cost was 85,000 yuan per unit and the factory gate price was 104,000 yuan. The retail price was 174,000 yuan. The difference between the factory gate and retail prices was accounted for by a purchase fee, localization fee and special consumption tax (Zheng Lixin 1994, p. 64). In 1988, the Shanghai municipal government levied what it called a "localization tax," which amounted to 16 percent of the retail price of Santana at the time. This enormous amount of fund was then plowed back as investments in Shanghai's supply sector. Between 1988 and 1994 , Shanghai collected over 5 billion yuan through this facility. Apart from provision of enormous financial resources, Shanghai government also acted to boost demand for Santana. It forbade the taxi companies in Shanghai to buy cars made elsewhere to staff their taxi fleet.

\footnotetext{
55 Thun (1999).

${ }^{56}$ Much of this localization drive by the Shanghai government is described in (Huang and Thun
} 1999). The writing of this case borrows significantly from the research and data collected by Eric Thun. 
This attempt at backward integration disrupted the existing supplier relationships that SAIC had already developed since the mid-1980s. Because the components industry in Shanghai was not developed, initially SAIC had no choice but to turn to existing components producers located in other provinces in order to economize on precious foreign exchange expenditures. Supposedly, SAIC was to create a "China brand, not a Shanghai brand." To that end, in 1987, SAIC signed long-term contracts to source components from thirteen firms based in Guizhou province in southwest China. Guizhou province, although not an industrial powerhouse, had built up a large aeronautical industry in the 1960s and 1970s as a part of Mao's "third front" program to move military-industrial production assets inland in order to shield them from a possible Soviet attack. Supplying components to SAIC provided an opportunity for Guizhou to convert their military production assets into civilian production assets.

In the 1990s, however, SAIC began to shift its components-sourcing away from firms based in Guizhou province, severing its ties with supplier firms in that province. This is what happened to Guizhou Honghu Machinery (Guizhou Honghu). Guizhou Honghu had a contract

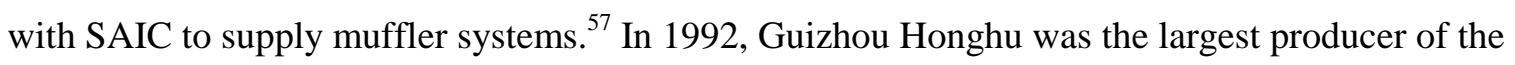
muffler systems, producing in that year 131,140 units while the production volume for Santana that year was 58,328. Guizhou Honghu solidified its market leadership in the next three years; by 1995 , its output volume increased to 225,000 units. During this period, the firm added capacity. Its employees grew from 2,870 to 2,890 . Its fixed assets grew from 47.65 million yuan to 65.63 million yuan. In constant prices, the firm's output value grew by 68 percent. However, in 1996, its output volume fell suddenly and precipitously, to 57,778, a reduction of almost 300 percent from the 1995 level.

What happened was that SAIC terminated its contract with Guizhou Honghu and turned to one of its own subsidiaries for its muffler systems. A Shanghai muffler producer increased its output volume from 175,000 in 1995 to 280,000 in 1996. The financial impact was immediate and dramatic. In 1995, the returns on assets were 2.26 percent for the Shanghai firm; in 1996, it increased to 15.8 percent. Guizhou Honghu's output value, in constant prices, plummeted by 28 percent in a single year. The firm, an SOE, cut its workforce drastically, from 2,890 to 1,276. In 1997, the firm did somewhat better as it now found other customers for its products. It apparently won contracts to supply to FAW-Volkswagen and Nanjing-Inveco for their Jetta and Iveco series.

\footnotetext{
${ }^{57}$ All the statistics cited in this following section are reported in (Ministry of Machinery Industry 1993, 1996, 1997b) and (State Bureau of Machinery Industry 1998b).
} 
Its workforce recovered to 2,829 but its financial performance continued to suffer. Its output value increased by 22.75 percent in 1996 but plunged again in 1997, by 23.6 percent, reflecting the high volatility of the this particular market segment without a stable source of demand for its products from the largest car manufacturer in China.

The systematic effort by SAIC to replace existing suppliers could not have happened without the high level of political support from the Shanghai municipal government. From the very beginning, the mayor's office set up a small "leading group" specifically to coordinate and supervise SAIC's regionalization strategy. Shanghai's mayor, who happened to be Jiang Zemin, China's current president, assured the small leading group of his full support. "When you have problems," he reportedly said, "come find me. We must maintain a hot line between us." Shanghai municipal government and the management of SAIC had an extremely close and revolving-door relationship. The current president of SAIC, Chen Xianglin, headed SAIC from 1983 to 1986 and then became the director of Shanghai Planning Commission until 1993. He then moved on to be the vice party secretary of the Shanghai Communist Party Committee in 1993 and 1994. In 1995, Chen resumed the presidency of SAIC, while his predecessor, Lu Jian took up a high level position in the Shanghai Municipal Economic Committee.

Central planning, as many comparative economists have pointed out, often fails to allocate goods consistent with the firms' requests; either the wrong goods are assigned or simply the requested goods are not supplied. This supply uncertainty gives rise to a strong incentive to engage in backward integration, i.e., investing in plants and facilities to produce inputs for final goods production. ${ }^{88}$ In the case of SAIC, the calculus was different from the traditional concern over supply uncertainty since SAIC bought directly from its suppliers and did not depend on the poorly informed bureaucratic decisions. Officially, the SAIC officials often invoked the very stringent quality and technical standard imposed by Volkswagen as a rationale for integrating operations backward. Indeed, SAIC faced a daunting challenge to obtain quality components. Wang Rongjun, the managing director of SVW, described the challenge facing the firm in the mid-1980s:

\footnotetext{
${ }^{58}$ For works along this line, see (Bauer 1978 ) and (Harrison 1985 ).

${ }^{59}$ This quote comes from (Upton and Long 1996).
} 
The technical standards of Chinese automobile component suppliers in 1986 were nearly 30 years behind component manufacturers of Europe, Japan, and the United States. For SVW, measures of technical excellence were in part defined by standards dictated by its European parent, Volkswagen AG. Furthermore, Chinese automotive suppliers in my time manufactured parts for trucks, not cars. We needed a fundamental shift, not only in parts design (as cars are a little different from trucks) but also in the technology. In the beginning there wasn't a single local parts supplier which could produce a part we could assemble into the Santana.

But, as the account of Guizhou Honghu makes clear, SAIC's regionalization drive in fact replaced existing suppliers that already successfully met the high quality standard of SVW. Thus product quality alone is not a sufficient explanation. The strong backward integration drive stemmed from a confluence of three factors. First, many regional governments targeted automotive industry for development and provinces with a comparative advantage in components production were motivated to expand into high-margin assembly operations. SAIC might have calculated very rationally that its dependency on suppliers located in other provinces could hurt its economic interests in the long run should supplier provinces divert components to their own assembly operations. Indeed, this is precisely what happened in Guizhou province. Throughout the 1990s, Guizhou province was contemplating to enter into production of a mini-car seriescalled Yunque series - and by 1994, 1,600 Yunque cars were produced.60

Second, in an industry dominated by inefficient SOEs, product quality was poor in general. Those firms capable of producing high-quality products were thus highly valued and could exert an enormous leverage over its vendors. For example, it could ask for a large price increase, knowing that SAIC would have difficulties replacing it. Thus a quality components supplier could threaten its vendor in the same way that Fisher Body threatened General Motors when General Motors depended on Fisher Body for a line of products only Fisher Body could produce. Quality, in an economy notorious for poor quality and scant attention to quality improvement, was a source of firm-specific advantage and bargaining power.

\footnotetext{
${ }^{60}$ Data for the 1994 production of Yunque are from (Ministry of Machinery Industry 1996).
} However, Yunque, which means skylark in Chinese, never took off. In 1998, its output volume remained low, at 1,064 units and the firm was losing money. See (Ministry of Machinery Industry 1999). 
Third, should components be diverted elsewhere, SAIC would have lost more than just a prompt delivery of quality components. It would have lost any spillover benefits associated with a long-term contractual relationship with its suppliers. The reason again has to do with the generalized low product quality in China's automotive industry. To cultivate Chinese supply firms to the technological and quality requirements acceptable to SVW—and ultimately to Volkswagen—required a massive transfer of money, time and knowledge from SVW to its suppliers. SAIC organized many technical training programs. Retired engineers from Germany were invited. SAIC provided technical assistance and introduced foreign firms to its suppliers in order to match the quality of the supply firms to the more advanced manufacturing processes at SVW. To raise the quality of the locally-produced components, Volkswagen transferred a testing lab from Germany to Shanghai and Volkswagen engineers worked closely with the supply firms to tackle quality problems. 10 A defection by an existing supplier could have been very costly to SAIC because along with the components the spillover benefits were diverted to SAIC's competitors as well.

In this situation, it would make perfect sense for SAIC to integrate backward to incorporate components production into assembly operations in order to internalize the spillover benefits from the assembly operations to components production. Indeed, at SAIC, most of the technical training was performed inhouse. SAIC established the Automobile Industry Training Center, which trained supply managers and technicians from SAIC affiliates. SAIC also rotated managers around different subsidiaries in order to diffuse knowledge and expertise throughout the SAIC system.

\section{To build or to acquire: The case of FAW}

The potentials of a hold-up problem involved in a supplier relationship across different political jurisdictions may motivate SAIC to resort to a backward integration. But why should SAIC have to build a supply base from scratch to fully capture the benefits from its financial and non-financial investments in the supplier firms? Could it, for example, simply acquire the supplier firm with whom it had an existing contractual relationship? An acquisition might have

${ }^{61}$ These efforts paid off. Over time, the quality of Shanghai supply firms did rise as a result, as indicated by the growing number of products that are assigned high grades in SVW's internal quality audits. Within SAIC, supply firms are assigned grades from A to C, A being the top grade. In 1990, only one supplier was assigned A; in 1997, twenty-seven firms were so designated. The number of B designees increased from 30 in 1990 to 203 in 1997. See (Huang and Thun 1999). 
been cheaper considering the extent of overcapacity in this industry. Reducing supply uncertainty tells us why firms in China want to integrate their downstream and upstream production but it does not tell us why they should choose to build a new facility rather than acquiring an existing facility. Why creating a new facility is often favored over acquiring an existing facility requires an understanding of those institutional factors that hamper the viability of asset acquisition across different jurisdictions.

A remarkable fact about the Chinese economy is that assets change hands infrequently even in situations in which no genuine ownership changes are involved, as, for example, when an $\mathrm{SOE}$ is transferred from one bureaucratic agency to another. According to (Shen Yifeng and $\mathrm{He}$ Yinqi 1998), the first merger and acquisition case took place in Baoding city of Hubei province in 1984. With the direct intervention from the municipal government, a textile machinery factory took over a smaller, loss making firm in the same city. In this instance, the acquiring firm took over the target firm in an administrative fashion, i.e., the acquiring firm simply assumed ownership over all the assets, debt and employees of the target firm at a zero cost. Since the two firms belonged to the same government agency, no financial resources were needed to consummate this "transaction." For the entire decade of 1980s, altogether 6,966 firms were taken over by outside firms, which involved a transfer of assets in the amount of 8.2 billion yuan. However, most of these merger and acquisition cases involved acquiring and target firms located in the same jurisdictions. In reality, these were not real mergers and acquisitions since they did not entail a change in the ownership. A better description of these cases is an organizational process of consolidating different subsidiaries belonging to a single firm rather than genuine asset transfers from one owner to another.

Again, as for much else in the Chinese economy, state ownership and control hampers asset transfers. The venue that would normally facilitate takeover activities across jurisdictions is notably inefficient in China to serve such a purpose-China's two stock exchanges. The reason is the stringent requirement that the government and state-owned entities retain majority equity interests in the listed firms and that their shares be non-tradeable. According to a detailed study of over 600 firms on Shanghai Stock Exchange (SHSE) and Shenzhen Stock Exchange (SZSE), in 1995, the three main groups of shareholders, the state, the legal persons and individual shareholders, each controlled about 30 percent of the outstanding shares. As long as the state and legal person shareholders together exercise controlling and non-alienable equity interests, the 
two stock exchanges cannot function as "markets for corporate control." "62 More active have been the smaller "asset exchange centers" that emerged in the major cities in the 1990s in response to the rising losses of the SOEs. In 1993 alone, it was reported in the Chinese press, 2,900 firms were sold or merged through this venue and the transaction value totaled some six billion yuan. Again, most of these transactions involved acquiring and target firms located in the same jurisdictions. Cross-jurisdictional mergers and acquisitions have been far fewer in number.

Other institutional factors impede asset transfers. First, because of the political control of firms, regional SOEs often serve valuable non-economic functions, which may attenuate the incentive to sell these firms even in situations when financial considerations warrant a sale. For example, a regional firm may promote employment in the locale or it may be the power base for the officials in the region regardless whether or not it is making money or not. Bureaucrats pursue multiple objectives and as long as retaining control of a firm serves one of these objectives, they may be reluctant to surrender the control of a firm to an outsider. Second, because SOEs are controlled by separate political entities, negotiating a sale of an SOE from one region to another is costly in terms of the necessary effort and amount of bureaucratic coordination required. For one thing, it is an extremely difficult to negotiate an acquisition price. Theoretically, all the SOEs only have one owner-the state-and because asset transfers have been administrative affairs, there has not been an accounting framework that readily determines the financial basis of an acquisition. The benchmarks are simply not there to guide these transactions.

A more important cause of high negotiation costs is that any given asset deal requires negotiations between two bureaucratic agencies. Direct communication between separate

\footnotetext{
${ }^{62}$ The reluctance to relinquish state's control rights over the listed firms is amply illustrated by the
} composition of the board membership. The board membership of the listed companies is not proportional to the ownership. Although individual shareholding constituted 30 percent of the outstanding shares, according to (Xu and Wang 1997), the boards of 154 companies that on average individual shareholders only occupied less than 0.3 percent of the seats on average but on the other hand the state was over-represented on the boards. On average, the state retained 50 percent of the seats even though its equity shares amounted to 30 percent. There are no proxy voting procedures, which puts individual shareholders in a disadvantageous position vis-à-vis the institutional investors such as a government agency. This usurpation of the rightful shareholder power is direct evidence that the state harbors no intention of relinquishing its control rights even over those firms that have been partially privatized. 
bureaucratic agencies is no easy affair because there is not a ready channel to facilitate such communication. Information flows flow up and down through vertical channels but not horizontally among equally-ranked bureaucratic agencies. This is a hallmark of a politically centralized system designed to maximize power and supervision of the central authority. In China, for example, agencies with equal ranks are explicitly forbidden to issue policy documents to each other. Central ministries and provincial governments have the same ranks and thus a ministry cannot dispatch decrees to a province even if the issue in question falls within the regulatory jurisdiction of the ministry. 1 In part because of these formal restrictions on direct communications and in part because of other informal mechanisms, China specialists use words such as "fragmented authoritarianism" to describe the operations of the Chinese bureaucratic system. 64

Probably, the best example of the kind of institutional impediments to crossjurisdictional acquisition is provided by a firm which has pursued an acquisition strategy most aggressively. This is FAW. The way it has acquired numerous facilities currently under its organizational umbrella provides a fascinating account of both the process and the requirements of asset acquisitions in the Chinese economy. FAW is known as the "cradle of automotive industry" during the PRC period. ${ }^{65}$ It was founded in 1956 and was one of the 156 large-scale industrial assistance projects the Soviet Union provided to China in the 1950s. FAW relied completely on Soviet engineering expertise, design and equipment. The first FAW product was "Jiefang" (or Liberation), a four-ton truck series designed by the Soviet engineers. Of the entire production, 81 percent of the parts came from the Soviet Union. In 1958, FAW produced China's first passenger car, "Red Flag," a luxury model based closely on the Daimler-Benz 200 sedan. 6 During the reform era, while SAIC spent heavily to create a supplier base in Shanghai, FAW

${ }^{63}$ This aspect of bureaucratic operation in China is dealt with in (Huang 1996).

${ }^{64}$ See (Lieberthal and Oksenberg 1988).

${ }^{65}$ China's first automobile manufacturer--Minsheng Factory—was built as early as 1919 and the first cargo truck was assembled in 1931. In 1936, the nationalist government established the China Automobile Production Company. The company received technical and production assistance from German manufacturer, Mercedes-Benz. But its volume remained low and then the Sino-Japanese war and the ensuing civil war disrupted the industry severely. The history of China's automotive industry is described in (Harwit 1995 ).

${ }^{66}$ The second car model, Phoenix, was introduced by Shanghai Automotive Plant, the predecessor of SAIC. 
acquired facilities across the country either as a market-entry strategy to venture into new product areas (such as light-duty trucks) or as a backward-integration strategy to acquire components-manufacturing capabilities (such as gears and engines).

What accounts for the ability of FAW to overcome the aforementioned institutional impediments to an acquisition strategy? The answer lies in the institutional configuration of FAW itself. FAW is a central-government firm. Its management is appointed by the Ministry of Machinery Industry (MMI) in Beijing and this means that Jilin province, in which FAW is located, exerts relatively little influences over the operation of FAW ${ }^{67}$ FAW's status as a centrally-controlled firm also matters for its funding and tax base. Most of its funds come from the central government, rather than from Jilin province. Conversely, most of its remittances go to the coffers of the central government rather than to that of the provincial government. In the Chinese planning parlance, FAW is known as a separately-listed firm in the central plan (jihua danlie qiye). For a separately-listed firm the investment funds and some of the requisite inputs FAW needs are allocated by the State Planning Commission of the central government directly rather than, as in the case of a locally-controlled firm, being allocated to provincial governments

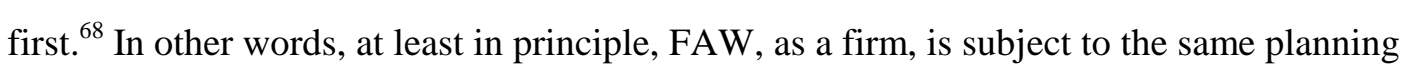
authority and control of the central government as the Shanghai municipal government itself. During the reform era, the function of material allocation by the central government has declined markedly. What turns out to be important for cross-jurisdictional acquisitions, however, is the organizational and coordination role of the central government.

In institutional terms, FAW and SAIC are two different firms, not in terms of the nature of their ownership as both are SOEs, but in terms of the levels of government that exercise those ownership rights. As pointed out previously, SAIC is a municipal-level firm and is subject closely to the supervisory authority of the Shanghai government. One indication of this difference between FAW and SAIC is the amount of state equity in these two firms. Traditionally, state equity is roughly proportional to the amount of equity interests held by the central government in a firm. In 1997, the state equity interests amounted to 89 percent of FAW's paid-in equity capital whereas they only amounted to 39 percent in the case of SAIC.

\footnotetext{
${ }^{67}$ In 1998, MMI was changed to State Bureau of Machinery Industry.

${ }^{68}$ State Planning Commission was changed to State Development and Planning Commission in
} 1998. 
This institutional difference means that an acquisition strategy is at least feasible for FAW (although still difficult, as shown below) but it is inordinately costly for SAIC. FAW can rely on the central government to coordinate communication and negotiation with different regional governments. For SAIC, a "build" strategy is more feasible because all the coordination and organization efforts take place within the municipal boundary of Shanghai. The difference in their strategies is indeed very sharp. One indication shows up in the ratio of spending on new plant and equipment purchase to the capital stock of these two firms. Because FAW built up its fixed assets via acquisitions, it spent modestly on new plant and equipment purchase, as a proportion to its fixed asset stock. In contrast, SAIC had a much higher ratio. Between 1990 and 1994, during a period in which both firms expanded rapidly, the ratio for FAW was 0.16 whereas it was 0.39 for SAIC. ${ }^{0 .}$ Another indication is the geographic location of the affiliates of the two firms. FAW is headquartered in Jilin province but fourteen out of its twenty affiliates-i.e., wholly-owned subsidiaries or firms in which FAW has a significant equity stake-are located outside of Jilin province. In contrast, despite the fact that SAIC has a greater number of affiliates, thirty-eight, not a single of its affiliates is located outside Shanghai. To be sure, on some dimensions, FAW is a larger firm but the national scope of FAW's operations and the regional focus of SAIC are not solely a function of the size difference between the two firms. Table 3 compares FAW and SAIC on a number of dimensions. FAW is larger in terms of asset and employment, but it is considerably smaller than SAIC as measured by sales and profits. The two firms are comparable in terms of production volume. Another piece of corroborating evidence that size difference did not determine the geographic scope of firms is the contrast between SAIC and China General Automotive Industry Corporation (CGAIC). CGAIC was a much smaller firm than SAIC. In 1997, it had 9.48 billion yuan in assets or about one fourth of SAIC and it generated a sales revenue of 6.5 billion yuan, which was about one-sixth of SAIC. Yet ten out of fourteen of CGAIC's affiliates were located outside the province of the headquarters of the firm. ${ }^{0}$ The reason is that CGAIC, like FAW, is a central government firm and thus it faces less constraints in its investment activities outside its province of its headquarters.

Table 3 about here.

${ }^{69}$ The denominator used in these ratio calculations is the original book value of the fixed assets. To control for depreciation allowances, we can also use net fixed assets. The result is the same. Purchasing new plant and equipment as a share of the net fixed asset stock was 0.36 for FAW but 0.65 for SAIC.

${ }^{70}$ Data are reported in (Ministry of Machinery Industry 1998). 
As a central-government firm, the negotiation costs for FAW to acquire assets crossjurisdictionally are relatively more manageable because of the facilitating role of the central government. According to a survey, most of the "acquisition" deals were not financial transactions. Instead, the assets were simply administratively assigned to FAW at zero costs. In such deals, the coordinating role of the central government is critical. In one of its acquisition deals, a vice premier of the State Council personally intervened to make it happen. Still, more often than not, FAW had to rely on informal connections rather than just interventions from the central government to facilitate its acquisition attempts. In two instances, the former governors of Jilin province, who became governors of the home provinces to the target firms at the time of acquisitions, made the arrangements that facilitated takeovers by FAW. 1

Administrative tax division rules have created obstacles to FAW's acquisition efforts, as indicated by the acquisitions it made in light-truck production. Today, FAW is the second largest producer of light-duty trucks in China. FAW, which was built as a predominantly medium-duty truck producer, rose to the top mainly through a number of acquisitions it made since the mid1980s but the particular travails of FAW's acquisitions illustrate the often stringent constraints on cross-jurisdictional asset acquisitions in the Chinese economy. In 1986, FAW began its lightduty truck production not by a straightforward acquisition but by contractual alliances with two light-duty truck producers. These two alliances eventually evolved into full acquisitions by FAW in 1991 and this process is interesting in several aspects. First, both of the truck producers were the so-called municipal enterprises, one under the Jilin city and the other under Changchun city. Because of the administrative tax derivation rules, a full acquisition by FAW would reduce the tax base of these two city governments and both agencies opposed such a move. The contractual alliance was a compromise in order to preserve the original ownership ties with the two city governments. Second, what is especially interesting about the institutional impediments in this instance is that FAW and the two truck producers were located in the same province, Jilin, and one even in the same city. This shows how powerful the institutional divisions are as even the natural pulling influences of geographic proximity were offset.

Third, the contractual alliance was unwieldy and inefficient and was created purely to deal with an institutional artifact such as the tax derivation rules rather than as a result of rational business considerations. Because assets of the two truck producers still belonged to their

\footnotetext{
71 These two provinces were, respectively, Yunnan and Hainan. The details of acquisitions by
} FAW are provided in (Unirule Economic Research Institute 1997) and (Sheng 1999). 
respective city governments, FAW could inject product lines, technicians, and managers into these two firms but it was unable to transfer production equipment and facilities from one firm to another. Thus the larger gains from production integration remained untapped and the production processes could not be optimized. FAW wanted the Jilin firm to assemble the one-ton trucks with chassis supplied by the Changchun firm whereas the Changchun firm would produce two-ton trucks with front body supplied by the Jilin firm. But FAW was prevented from integrating and transferring assets and instead the two truck producers kept their own duplicate facilities in chassis and front-body manufacturing equipment.

In the end, in 1991, FAW eventually took over these two truck producers but under sharply different circumstances from the ones prevailing in 1986. Light-duty truck production became congested and the two truck producers began to incur large losses. This changed the calculus of the two shareholding city governments. Selling off these two firms became a way to reduce liabilities. Still in one of the acquisitions, FAW had to create a subsidiary in the Jilin city that was designated as a municipal enterprise for the sole purpose of paying income taxes to the Jilin city government.

As the story of FAW's acquisitions of the two truck producers show, social motivations and functions play an important role in the acquisition activities in China. Because of this emphasis on the social functions, more economically-oriented regional governments shun acquisition as a strategy to integrate production. By default, a "build" strategy is often thought of as facilitating economic objectives. This plausibly explains why SAIC has systematically favored a "build" strategy. FAW, being a central firm, is more susceptible to social considerations of the central government and it has been compelled to acquire loss-making operations in a number of instances. A good example here is the acquisition by the FAW of Jinbei Shareholding Corporation in Liaoning Province in 1995. Jinbei produced light passenger vans and FAW was contemplating to move into this product segment. But the deal was far from ideal from the perspective of FAW. Jinbei had been performing poorly. In 1994 even when the entire automotive industry was expanding rapidly, Jinbei's pre-tax profit to asset ratio was only 1.8 percent as compared to the industry average of 4.6 percent. Jinbei also had a lot of nonproduction assets on its balance sheet, at 48.57 percent as a proportion of the total fixed assets. Non-production assets refer to those assets that do not generate any cash flows and represent a

\footnotetext{
${ }^{72}$ This account is given in (Unirule Economic Research Institute 1997).

${ }^{73}$ (Ministry of Machinery Industry 1995, p. 377).
} 
firm's investments in provision of social services, such as employee housing, canteens, bathhouses, schools, and hospitals, etc. Jinbei's high non-production asset ratio would impose heavy burdens on FAW as the takeover of Jinbei called for a large injection of production assets and financing its high levels of social services out of FAW's operating income. But in the end, the deal went ahead largely because the central government prevailed upon a reluctant FAW.

\section{Economic fragmentation and FDI}

In the previous sections, we have examined the processes and outcomes of economic fragmentation in China. In this section, we turn to the FDI question and examine the relationships between economic fragmentation on the one hand and FDI on the other. The claim I am making is that economic fragmentation makes FDI more valuable to Chinese firms and regional governments than otherwise would be the case. It is helpful to recall a startling fact that I presented in Chapter 1 of this book: The tiny Macao held a larger investment position in China than the powerful Guangdong province did in the rest of China. These are not just two intriguing and innocuous economic facts; in fact they are intimately connected. That firms based in Guangdong found it difficult to invest outside the province might have contributed to a greater inflow of FDI from Macao.

Economic fragmentation increases the bargaining power of foreign firms because domestic firms cannot bid for projects or assets cross-jurisdictionally whereas foreign firms could. In effect, economic fragmentation makes China's asset market less contestable than it would ordinarily be. The mechanism is simple. Because there are no similar constraints on the mobility of foreign capital, foreign firms are free to fund operations wherever there is a capital shortage but domestic firms are constrained from doing the same. This means that in effect foreign firms as a whole have many more projects to choose from than domestic firms and that, for any given fundable project, foreign firms are essentially competing with other firms rather than having to compete with domestic firms as suppliers of capital. The overall effect is that some foreign firms have come to play a financing role that is often disproportionately large relative to their financial, technological, and managerial prowess.

The example of CSI, outlined at the beginning of this chapter illustrates this dynamic very well. CSI was founded by Oei Hong Leong, an Indonesian businessman with a reputation of 
a corporate raider in Asia and with a somewhat troubled business history in Singapore. ${ }^{\text {In }}$ In 1991 , Oei bought a Hong Kong company called Ruby Holdings and renamed it CSI. Ruby Holdings was listed on Hong Kong Stock Exchange and was a medium-sized company primarily focused on restaurants, garments and real estate. Oei himself had come primarily from a background of asset trading and deals rather than any deep experience in industry and manufacturing. With the founding of CSI, he began to focus on manufacturing concerns. In 1992, he acquired majority controls of another listed company, Holian Investments, a manufacturer of household goods which operated production in China. ${ }^{5}$ Its Hong Kong-related businesses apparently generated only 84 million dollars in 1992.

After Oei suffered a debacle in Singapore, a Singaporean journalist cautioned Oei to learn from seasoned business people such as Li Ka-shing of Hong Kong and Liem Sioe Liong of Indonesia. "[P]erhaps," she wrote, "they know when to leave the big-stakes game to the big boys." 16 Apparently, Oei never learned the lesson. From a humble beginning, CSI was on an acquisition binge in China between 1992 and 1994 and took over some 200 companies at a time when Chinese economy was growing at 11 percent a year. CSI was poised to become a huge business empire in China overnight with controlling equity stakes in numerous manufacturing concerns ranging from tires, brewery, aluminum to machine tools. His acquisitions spanned the entire country. The first break for CSI came in July 1992 when CSI bought controlling interests in forty-one SOEs in Quanzhou city in Fujian province in one fell swoop and then in another deal, in 1993, CSI took control of 101 factories in the northeastern city of Dalian in Liaoning province. Between 1992 and 1994, CSI was on an acquisition binge and it took over some 200 companies in China in diverse businesses and a number of its affiliates emerged to be the largest players in their lines of business overnight, from brewery, tires, chemicals, to machinery. In 1992, CSI acquired controlling stakes in two tire manufacturers, one in the city of Hangzhou and the other in Shanxi province. Overnight, CSI became a dominant player in China's tire business. Its affiliate, China Tires Holding Limited, became the largest tire manufacturing group in China

${ }^{74}$ In one of his takeover bids, he apparently ran into troubles with the regulators when he selectively disclosed information to some investors but not others. A commentary in the Singaporean newspaper, Business Times, had this to say about Oei, "He appears, rightly or wrongly, to be ready to sacrifice long-term management at the altar of short-term profits. And no number of headline-grabbing deals will wipe out this wheeling-dealing image overnight." (Ong 1992)

${ }^{75}$ See (Lee 1992).

76 (Ong 1992). 
within one year of CSI's investments. In 1993, China Tires accounted for 10 percent of tire production in China. In July 1993, CSI listed China Tire Holding Limited (China Tires) on the New York Stock Exchange. China Tires was incorporated in Bermuda and held controlling interests in tire manufacturing firms in China. Its listing raised 97 million dollars net of expenses, which richly rewarded CSI. It was reported in the press that CSI had invested 20 million dollars in these tire concerns. Between 1993 and 1996, CSI used the IPO proceeds to finance additional acquisitions of tire-manufacturing facilities as well as significantly upgrading its existing tire production. Between 1993 and 1996, China Tires acquired controlling interests in four more Chinese tire producers and two international tire companies (one based in California and one based in British Virgin Islands).

Apart the suppression of funding opportunities available to domestic firms, there are other subtler connections between economic fragmentation and FDI. The most important effect of economic fragmentation is that it makes Chinese firms less competitive than they would be otherwise. Less competitive Chinese firms increase the relative advantage of foreign firms and, as consistently argued in this book, relative advantage of foreign firms is a good predictor of FDI. In the following paragraphs, I will first present a number of hypotheses spelling out the theoretical linkages between economic fragmentation and FDI inflows. The next two sections present some corroborating evidence.

\section{Institutional foundation hypotheses}

There are several mechanisms whereby economic fragmentation can contribute to a greater demand for FDI. One mechanism is straightforward. A fragmented market may make Chinese firms less competitive than their economic potentials allow and to the extent that weakness of domestic firms induces FDI (in the presence of large market potentials) FDI rises as a response. Thus economic fragmentation affects Chinese competitiveness exactly in the same way as a poor allocation of financial resources-by rendering Chinese firms uncompetitive across the board and by raising the relative competitiveness of foreign firms in the process. The prediction that FDI rises in this scenario is directly derived from our framework used throughout this book that FDI is a function of relative advantages of foreign over domestic firms.

The above argument rests on a notion that a small home market contributes to firm uncompetitiveness. The logic here needs to be spelled out more fully rather than being taken on its face value. There are two issues. One is the linkage between home-as opposed to foreignmarket on firm competitiveness; the other is the linkage between the size of home market and 
firm competitiveness. On both questions, Michael Porter's analysis of determinants of national competitiveness is most helpful. According to Porter, home base of a firm plays a disproportionate role in creating and shaping national competitiveness at the firm level. Home base consists of both production factors as well as demand-side factors. A firm is more likely to attain competitiveness - as measured against the best in the world-if it operates in an environment with the right home base conditions. Between production factors and demand-side factors, Porter stresses the demand-side factors as especially important. 7 Managers are more likely to pay attention to buyer needs and characteristics nearby rather than to those far away. They also understand home buyers better. There is "an intuitive grasp of buyers' circumstances" that cannot be achieved with foreign buyers. Without cultural complications, communication is easier and free of misunderstanding between buyers and producers of the same country.

There are many demand-side factors in Porter's analytical framework. Of particular relevance to our analysis here are the size and the quality of home market demand. The effect associated with the size of home market demand on firm competitiveness is not obvious. Countries often thought of as having a small market, such as Switzerland, Sweden, Korea and even Japan, boast of many of the most preeminent firms in the world. Indeed, precisely because of the small size of their markets, firms in these countries were pressured to export and to excel on the global market. "Home market size proves to play a complex role in national advantage," as Porter remarks (Porter 1990, p. 92-93), "and other aspects of home demand are as or more important."

With that caveat in mind, a large home market still entails a number of advantages, especially in the Chinese context in which a compression of home market demand does not readily translate into export pressures. ${ }^{69}$ For one thing, as Porter points out, a large market confers "static efficiency" on firms operating in those industries characterized by economies of

${ }^{77}$ Any nation, he argues, has some "attractive factor pools" and the critical challenge is not the presence of appropriate factors but their efficient deployment. In addition, globalization has made it possible for firms to source factors of production beyond their borders.

${ }^{78}$ Apart from production factors and demand-side conditions, Porter also deals with the importance of related industries and firm strategy. These four aspects reinforce each other to constitute what he calls "national diamond," a system that determines the competitiveness of nations. See (Porter 1990).

${ }^{79}$ The lack of a compensating export outlet is important for our analysis. After all, the logic that a large home market does not matter does not rest on the notion that a large market size per se does not matter but that an export market often entails very exacting conditions on firms operating in that market. 
scale. One consequence associated with economic fragmentation in China is the persistence of high average production cost. For example, even for the largest car producer in China, SVW, its production cost was several multiples of import prices of comparable foreign cars. In 1991, the unit price for the Santana model was 173,000 yuan; a similar import only cost about 40,000 yuan before tariffs. Quality of home market demand, as much as or more than the quantity of home market demand, has a strong bearing on national competitiveness in Porter's analysis. Sophisticated and demanding buyers prod firms to innovate and to invest in continuous product improvements. They also help firms identify the needs of most advanced buyers. In Porter's analysis, much of the Japanese success, in products ranging from air-conditioners, camera, and pens, derived from the tough demands placed on Japanese firms by Japanese buyers. Diversity of demand conditions also fosters competitive advantages. According to Porter, commercial airconditioning industry is advanced in the United States because the country encompasses practically all the conceivable climatic and industry conditions. 30

Porter's analysis of Japanese success takes as given a fundamental condition necessary for national competitiveness - the existence of vibrant domestic competition. This is the fourth corner of Porter's diamond framework and it is among the most important factors in his conception of what makes a nation competitive. ${ }^{1}$ China fails this basic test, by a long shot. Artificially carving a single market into several smaller segments lowers the quality of home market demand. The effect of trade protectionism and capital controls at the regional level is that firms operate as near monopolies in their highly regionalized markets and in pockets of high profits. The degree of rivalry is sharply reduced. Deprived of choices, Chinese buyers are captive in those product segments targeted by regional governments. For example, it would be hard for taxi companies in Shanghai to staff their fleets with anything other than Santana and it would be hard for SVW to source its components from firms other than the affiliates of SAIC. These are not demanding market conditions that compel firms to be innovative and to make huge investments in product improvement. The effect on firm competitiveness is vividly-and

${ }^{80}$ This section draws from (Porter 1990, especially, pp. 86-91).

${ }^{81}$ As he puts it, "Among the strongest empirical findings from our research is the association between vigorous domestic rivalry and the creation and persistence of competitive advantage in an industry." See (Porter 1990, p. 117). 
somewhat hilariously_illustrated by Li Lanqing, China's vice premier, recounting his experience of a visit to a truck factory:

What is really interesting is my visit to a factory in Chongqing, producing a certain "Liberation" truck. But the name of the truck was not Liberation; it was, instead, "Forever Forward." I commented that you got a good name, indicating your willingness to march forward bravely. He [the manager] replied that in fact it was a literal name. The truck did not have a reverse gear; it could only move forward.

Economic fragmentation also diminishes a natural and huge advantage China has over many other developing countries: The diverse demand conditions created by its vast geographic expanse. China is comparable to the United States in physical size and it encompasses extremely diverse geographic, climatic, social and economic conditions. In addition, the rural/urban contrast is sharp. These would be propitious conditions to foster firm competitiveness. A firm that meets the heterogeneous market conditions and demands at home is better prepared to compete globally. Economic fragmentation, in essence, decomposes a single market with many heterogeneous attributes into smaller and individually homogenous segments. Thus a factor-its natural diversity - that ought to foster national competitiveness is greatly diminished. It is no accident that twenty years of rapid economic growth has not led to the emergence of a single globally competitive Chinese firm.

So far, our analysis has focused on the impact of economic fragmentation on the nature of demand-side factors in curtailing Chinese competitiveness (and by extension, raising Chinese demand for FDI). There are also supply-side factors at work and the supply-side factors increase demand for FDI because creating and sustaining a fragmented economic structure is an economically costly proposition. Firms may have to invest more or more firms invest in capitalintensive industries than they would otherwise. Greater demand for capital translates into a larger demand for FDI.

The kind of regional integration strategy SAIC undertook basically means that China foregoes the economic gains from the existing regional patterns of comparative advantages. Guizhou province, as our account makes clear, had already developed a comparative advantage in automotive components but SAIC's systematic effort to create a supplier base in Shanghai in

\footnotetext{
${ }^{82} \mathrm{Li}$ Lanqing recounted this episode in a speech he gave in 1993. The speech was printed in
} (Beijing Haitehua Machinery and Electric Technology Development Corporation 1994). 
essence amounts to an effort to shift such a comparative advantage to Shanghai. But such an effort costs money on the one hand and results in wastes and duplication on the other. To reinvent the wheel in Shanghai requires additional capital spending. Because SAIC chose a "build" strategy rather than acquiring the Guizhou facility, Guizhou's existing facilities were simply rendered useless.

Second, fragmentation in an industry — such as automotive industry—characterized by scale economies is costly, as already mentioned. In an industry with large scale economies, the average costs fall as the output volume increases. This means, all else being equal, a fragmented industry structure incurs a higher average cost per unit of output as compared with a concentrated industry structure. Not only are production costs a falling function of production volume, investment costs also fall as the incremental output range gets large. A Chinese study shows that investment costs for adding facilities fall as output capacity increases. For example, the investments would increase by 40 percent when output capacity doubled from 100,000 units to 200,000 units [Wu, $1997 \# 1709]$.

Third, it is well-known that an import substitution strategy favors capital-intensive industries. Regional import substitution strategies duplicate capital-intensive industries and amplify the capital bias by many folds. The logic is straightforward. Under a single national import substitution strategy, it is still feasible for different regions of the same country to produce along their own comparative advantages even though the entire country as a whole may not do so. Regional import substitution strategies in effect mean departures from the principle of comparative advantages across the board and are likely to worsen the capital bias even more.

\section{Regional import substitution strategy and FDI}

Regional integration implies foregoing a sourcing option based on the existing patterns of comparative advantages of Chinese provinces. Doing so is not cheap, especially in an industry with scale economies, such as automotive industry. Building a completely new facility is more expensive than expanding an existing facility because a substantial portion of the facility is "volume-invariant." One needs to complete an entire assembly line whether it assembles one vehicle or 10,000 vehicles a year. When SAIC decided to build a muffler production facility of its own when Guizhou Honghu already operated on a substantial scale, more capital expenditures were required than if SAIC had continued to source from Guizhou Honghu and had significantly increased the size of its orders. 
The added resource requirements have to be met somehow. For SAIC, one way was to mobilize domestic resources in order to invest aggressively in the development of a components sector. The costs were mainly borne by the Chinese consumers who were charged an exorbitant price for Santana, a car model that was obsolete in Europe as of the late 1970s. As mentioned before, the Shanghai government levied a "localization tax" between 1988 and 1994 for the specific purpose of building a components sector in Shanghai. SAIC, rather than Volkswagen, was the main beneficiary of the supernormal profits on Santana and of the localization tax. The joint venture contract with Volkswagen gave SAIC the exclusive marketing right over Santana and thus SAIC, through its sales division, reaped most of the financial gains. In 1994, the factory gate price for a stripped-down Santana was 106,000 yuan; the retail price (exclusive of various purchasing fees) came to 168,000 yuan. The ratio of retail to factory-gate prices, at 1.58, was by far the highest among all the passenger vehicle producers in China. 3 SAIC then plowed back this enormous amount of profits into its components sector.

The other way was to actively solicit help from MNCs. Herein lies the connection between regional import substitution strategy and FDI demand. A regional import substitution strategy creates a fund shortage that otherwise would not exist (or it made an existing fund shortage more severe than it needed to be). To make up any shortfalls in funds, MNCs are courted and are made more valuable. An FDI demand of this sort is driven by an institutional imperative, less by the actual business needs of sourcing price-competitive and quality components.

It is important to be specific about precisely why building a supplier base in Shanghai would lead to a higher FDI demand. In our example about SAIC changing its sourcing of the muffler systems, neither Guizhou Honghu nor the replacement firm in Shanghai were FIEs and thus FDI was not involved. However, our hypothesis does not require there be a direct linkage between replacing imports from foreign provinces and FDI. The reason is that money is both a fungible and finite resource. The amount of money that was spent to create a muffler firm in Shanghai could not be used to do other things. For example, the money was not available to invest in a project to produce a component that was not available anywhere in China. (Doing so was necessary because the government imposed localization schedules on Chinese automotive firms.) In essence, SAIC needed to replace imports from foreign provinces and from foreign countries at the same time. To do that, SAIC would have to raise additional capital elsewhere. To

${ }^{83}$ Price data are given in (Ministry of Machinery Industry 1997a). 
relate this reasoning to the measure we have been using as an indicator of FDI preferences, foreign equity proportion of FIEs, the money SAIC spent on replacing its existing suppliers could not be used to finance SAIC's equity stakes in its joint ventures with MNCs and its equity stakes would be lower as a result.

Throughout this book, we have used foreign equity proportion of FIEs as a measure of Chinese FDI preferences. The larger the foreign equity proportion are, the stronger Chinese FDI preferences are said to be. Although this measure is not perfect, short of alternative measures, this is probably the best proxy that we can find. Here we use foreign equity proportion as an indicator of the extent of SAIC's demand for FDI. A logical inference of our analysis is that SAIC should exhibit a greater demand for FDI as compared with other automotive firms with a less aggressive regional import substitution stance. Compared to those firms, SAIC should have conceded more corporate controls over its affiliates to MNCs.

Table 4 presents information on the various characteristics of FIE affiliates within four major automotive business groups, SAIC, BAIC, Tianjin Automotive Industry Corporation (TAIC), and Guangzhou Automotive Industry Corporation (GAIC). Until recently, these four groups were the dominant players in China's car production. (In the late 1990s, other car producers came on line such as FAW's joint venture with Volkswagen to produce Audi and Jetta series and a joint venture between Dongfeng Motor Corporation and Citreon to produce a Fukang series.) TAIC was a specialist in a mini car, Charade (Xiali in Chinese), which was widely popular with households and smaller taxi companies. TAIC had a joint venture with Toyota for its engine production but the car assembly division was controlled by TAIC itself. GAIC created a joint ventures in car production in the same year as SAIC, in 1985. The joint venture, Guangzhou Peugeot Corporation (GPC), was with Peugeot of France, and at its height, in 1993, churned out 16,765 mid-size cars. Plagued by a small volume and chronic losses, Peugeot withdrew from the joint venture in February 1997. (Honda took over the Peugeot facility in 1998 to assemble its Accord model.)

These four firms are comparable on a number of critical dimensions. All four were municipal firms under direct controls by the city governments. They were all primarily car and single-vehicular producers. Thus comparing them rather than with multi-vehicular firms such as FAW and Dongfeng Motor Corporation implicitly imposes a control on differences in technology, nature of market demand and production processes. All four of them relied on MNCs for design, engineering expertise, and financial resources for their vehicle assembly operations (although, as will be shown later, the degree of their reliance differed). One important difference 
lies in the extent they pursued a regional import substitution strategy. SAIC carried out a methodical and systematic strategy to backward integrate into components production. TAIC adopted a similar strategy, albeit with less fanfare. In contrast, both BAIC and GAIC were "laissez-faire" in their approach and did not actively venture into components production. Table 4 about there.

The contrast in their integration strategies can be shown in a number of ways. The components production under SAIC and TAIC increased their importance between 1992 and 1997 substantially. As shown in Table 4, the share of components production doubled in the case of TAIC, from 14.3 percent to 30.5 percent, whereas it increased more than 50 percent in the case of SAIC (from 17.8 percent to 27 percent). The increase in components production is across-the-board, as measured by employment and net fixed assets (not shown in the table). By those measures, it is clear that BAIC and GAIC did not stress the development of components production nearly as much. For BAIC, components production in fact declined, from 21 percent in 1992 to 17.4 percent in 1997. GAIC witnessed a small increase in the components production but since it started from a de novo position in 1992, the increase, by 5.6 percent, is almost inconsequential. SAIC and TAIC also invested heavily in components production. In 1997, 81 percent of new fixed asset investments made by SAIC went to the components firms; for TAIC, the figure was 63.7 percent. For BAIC, it was only 4.5 percent and it was 10 percent for GAIC.

Table 4 gives the simple arithmetic averages of foreign equity proportion in percentage terms. There is some, although not overwhelming, evidence, that higher a movement into components production is associated with greater foreign equity stakes. FIEs within TAIC have, by far, the highest foreign equity ratios, at 53.3 percent. BAIC has the lowest ratio, at 44.8 percent. GAIC has the second highest ratio, at 49.6 percent, but its ratio is not substantially higher than that of SAIC. In addition, the foreign equity proportion of GAIC FIEs is somewhat inflated by including two wholly-owned FIEs. Wholly-owned FIEs are rare in this industry because of the governmental restrictions. The fact that GAIC had two of them must be attributed to the status of Guangdong province as a special economic zone. When these two wholly-owned FIEs are dropped from the calculation, the foreign equity proportion come down to 47.1 percent. At this level, SAIC and GAIC are quite comparable in terms of the extent of foreign ownership controls.

\footnotetext{
${ }^{84}$ The foreign equity data given in the text are arithmetic averages and thus are not weighted by the
} size of FIEs. It is possible, for example, that SAIC owned more of its larger FIEs than smaller FIEs while 
Before we draw the conclusion that a deep integration strategy on the part of SAIC and TAIC resulted in greater foreign equity holdings, a number of alternative hypotheses must be considered. First, we must consider the role of FDI regulatory environment in influencing the extent of foreign ownership controls among these four firms. Some regions are more liberal than others in their policies toward foreign equity controls. To the extent that FDI regulations played a role, it ought to reinforce our conclusion. Guangdong is, by far, the most liberal province in its FDI policies and Shanghai is considered to be the most stringent. Yet, as shown above, the differences between the two provinces are not substantial. If one is to exclude the two whollyowned FIEs from Guangzhou data, the foreign equity proportion of GAIC FIEs is almost identical to that prevailing within SAIC. This is a startling result: The two provinces on the opposite spectrum of FDI policy restrictions end up with roughly the same levels of foreign equity holdings.

MNCs seem to have been more active in Shanghai. Compared to Beijing at least, MNCs had gone to Shanghai earlier. Before 1990, only three joint ventures were established in Beijing as compared with six in Shanghai. Even before the dramatic rise of FDI inflows into China, FIEs played a far more important role in automotive industry as sources of employment, output and financing in Shanghai. In 1992, joint ventures accounted for 2.36 percent of industrial output value, 2.66 percent in employment and 2.17 percent of net fixed assets in Beijing. But in Shanghai, the shares were much higher. FIEs in 1992 accounted for 4.77 percent of industrial output value, 13.94 percent of employment, and 14.55 percent of net fixed assets. ${ }^{65}$ The larger role of FDI in Shanghai's automotive sector was not a result of greater receptivity of Shanghai to FDI during the 1980s. Foreign investors in Shanghai often complained about long delays in the approval process and complicated bureaucratic procedures, a perception, in the words of a study on this issue, that "resulted in an increasing distance between the speed of foreign capital utilization and growth rate between Shanghai and its brother provinces." Nor was the larger

BAIC had the opposite combination. If this is the case, then the simple arithmetic averages would be misleading. However, this is not the case. For 1998, we have paid-in capital data on a consolidated basis and these data show that TAIC and SAIC had bigger foreign equity holdings than BAIC. (Data for GAIC are not available.) For TAIC, the foreign equity holdings of its affiliates came to 39.8 percent; for SAIC, it was 31.7 percent. For BAIC, it was only 20.5 percent. Data are from (State Bureau of Machinery Industry 1999).

\footnotetext{
${ }^{85}$ Calculated from (Ministry of Machinery Industry 1993).

${ }^{86}$ See (Luo Gengmo 1994) .
} 
role of FIEs in Shanghai's automotive industry a result of larger FDI inflows into Shanghai in the 1980s. In 1988, FDI inflows into Shanghai amounted to about 72 percent of what Beijing got. Shanghai was not a magnet for foreign investments until the central government granted SEZ status to Shanghai in 1991. By 1992, Shanghai quickly caught up with Beijing and the FDI inflows into Shanghai amounted to 226 percent of Beijing's FDI inflows in the same year, a gap that has grown to 256 percent by 1997.

Another hypothesis is that the attractiveness of these four business groups to MNCs varied and more attractive firms could obtain more FDI at a given level of Chinese control. However, just as the last hypothesis, this hypothesis should predict SAIC to be less controlled by MNCs. SAIC was considered a far more desirable JV partner to MNCs than either BAIC or GAIC. SAIC operated at higher profit margins and enjoyed sustained and dedicated support from the Shanghai government. It built up a huge war chest of capital from the exorbitant prices it charged to Santana buyers. It dominated China's car market. Its management was viewed by many as competent and modern in its outlook. In two instances at least, SAIC used its considerable financial prowess to buy back stakes from foreign shareholders. One was Shanghai Yanfeng, a joint venture with Ford Motor Corporation to produce interior trimming parts. The joint venture was established in 1994, with Ford holding 51 percent of the equity. SAIC later increased its holding to 50 percent. Compared to SAIC, BAIC was in a far weaker bargaining position vis-à-vis MNCs and it had to cede ownership controls to MNCs over time. BAIC initially held 69 percent of the equity stake in BJC but in 1990, it reduced its stake to 62 percent and then to 58 percent in 1994. Yet our data in Table 4 which incorporated these two equity adjustments, still show greater foreign equity holdings on the part of SAIC.

A slightly different hypothesis from the above states that firms with greater bargaining power should be able to maintain greater ownership controls over the future cash flows. SAIC and TAIC, because of their greater profitability and superior performance, should be able to negotiate better equity terms than BAIC and GAIC. The greater foreign ownership shares of the FIEs of SAIC and TAIC are, thus, inconsistent with this version of the bargaining perspective. Another test of the bargaining perspective is to assess the changes of foreign equity proportion over time. As is well-known, compared to the 1980s, China in the 1990s became far more

${ }^{87}$ If these equity adjustments are not made to the data, BAIC's foreign equity holdings would be reduced from 44.8 percent to 44.1 percent. SAIC's foreign equity holdings would increase from 47.4 percent to 47.5 percent. 
attractive to MNCs and the major automotive MNCs were knocking each other over in order to get into China. Chinese firms, thus, in the 1990s should be in a stronger position to negotiate with MNCs simply because the supply of FDI was much greater.

Our data again contradict this expectation. For both SAIC and BAIC, the foreign equity proportions of those FIEs established in the 1990s are larger than the ones for the entire sample while for TAIC and GAIC they are about the same. 8 Thus SAIC and BAIC seem to have lost bargaining power vis-à-vis MNCs. Of course, this pattern might have resulted from a confluence of several developments. In the 1990s, the FDI regulatory environment became more liberal and thus an increase in the foreign equity holdings is not surprising. What may be a bit unexpected is that foreign equity holdings should have increased to the same extent between SAIC and BAIC. As pointed out before, during the course of the 1990s, the paths of SAIC and BAIC diverged sharply. SAIC rose from behind to the top of the Chinese automotive industry whereas BAIC atrophied over time. One would expect to see BAIC grow more desperate for foreign capital than SAIC when in reality SAIC exhibited as strong — or stronger-a preference for FDI.

Another hypothesis is that foreign equity proportion should vary inversely with the profitability of Chinese investing firms. More profitable Chinese firms would need less of foreign capital and less profitable ones would need more. The profitability differences among these four Chinese business groups reinforce, rather than weaken, our conclusion. SAIC and TAIC were by far the more profitable firms as compared to BAIC and GAIC. Their returns on assets were 27.2 percent for SAIC and 29.8 percent for TAIC in 1992. The same measures for BAIC and GAIC were only 15.1 percent and 10.4 percent. One would predict, all else being equal, SAIC and TAIC to be more "choosy" and less willing to make equity concessions, precisely the opposite outcome from the actual observations.

Finally, one can argue that the types of foreign investors differed among these four business groups, which might have led to different patterns of foreign equity holdings. For example, although SAIC had more bargaining power than other Chinese firms, they might have negotiated with the most preeminent automotive firms of the world. Indeed foreign investors who had teamed up with SAIC read like a who-is-who list of the largest automotive MNCs of the world. GM, Ford, TRW, Volkswagen, Delphi, and Hughes Electronics have all maintained

${ }^{88}$ The data for TAIC are heavily influenced by the fact that only one FIE was established in the 1980s under TAIC. There is thus a data selection problem for the TAIC data since the foreign equity patterns for the 1990s are essentially compared to the equity structure of one firm. 
investment positions in Shanghai. The preponderance of the premier MNCs in Shanghai is indicated by the much larger size of investments in Shanghai. Table 4 shows that the average paid-in capital for FIEs under SAIC amounted to 40 million dollars, in comparison to much smaller amounts for other firms.

While the difference in investor types may have contributed to the varying foreign equity holdings between SAIC and other firms, this explanation alone cannot account for the difference between TAIC on the one hand and BAIC. The size of paid-in capital of TAIC affiliates is smaller than that of BAIC (20.6 million dollars compared to 23.9 million dollars), but the size of foreign holdings is much larger (53.3 percent compared to 44.8 percent). The composition of foreign investors in Tianjin is not noticeably different from that in Beijing. To the extent that there is a difference, Japanese investors were more active in Tianjin but this difference should have resulted in a lower, not higher, foreign equity holding in Tianjin. By reputation, Japanese investors are more willing to accept minority shareholder status as compared to American investors.

\section{Economic fragmentation and FDI fragmentation}

In the previous section, we have shown that firms such as SAIC and TAIC which pursued an aggressive integration strategy would be more eager to source FDI. They could court foreign investors by easing the terms for MNC entry and by allowing MNCs to claim a greater proportion of cash flows of future automotive industry growth in China. FDI rose because for a

given unit of future business opportunity in China the investment costs were lowered. This is one avenue whereby economic fragmentation may have increased China's FDI inflows. Another avenue is through a greater dispersion of FDI-financed facilities. As the example of SAIC shows, to be able to supply to SAIC, an MNC needed to form an equity alliance with SAIC. (It is also possible that the same dynamics worked at TAIC as well.) The result is that an MNC might have to invest in three facilities in order to supply to three vehicle producers even in situations in which one facility might have been sufficient to supply to all three. If there are scale economies involved and if the assets are somewhat indivisible (i.e., the entire facility needs to be constructed whether 100 or 100,000 units are produced), the investment costs would be higher than in the absence of economic fragmentation. The money which would finance operating budget and volume expansions ended up financing capacity creation instead.

There are a number of examples of MNCs having to invest in several facilities in order to supply to different vendors. One example concerns seat belts. Until 1997, SVW bought all of its 
seat belts from a supplier in city of Nanjing, in Jiangsu province. The Nanjing supplier was a joint venture with Autoliv, Inc. of Sweden, which is one of the largest producers of seat belt and air bag systems in Europe. Volkswagen, SVW's German shareholder, is a large customer of Autoliv and Autoliv often followed Volkswagen in its investments abroad. The Brazilian subsidiary of Autoliv, for example, supplies seat belt and air bag systems to Volkswagen. Its Chinese joint venture was formed in 1990 with the intention to supply seat belts to SVW. The joint venture began with a total capitalization of 3.5 million dollars. Autoliv Group and its Chinese partner, a military firm which had previously produced parachute gears, each held 50 percent in the venture. For a while, the JV was doing very well. By 1996, it was the second largest producer of seat belts in the country, accounting for 22 percent of the market. The returns were good. In 1995 its gross profit margin was 23.7 percent with an output volume of 430,000 units.

In January 1997, a subsidiary of SAIC, Shanghai Clutch Factory, formed a joint venture with TRW-Shanghai TRW Automotive Safety Systems Corporation-to produce seat belts. As soon as the in-house production began, immediately SVW switched its seat belt supplier from Nanjing-Autoliv to Shanghai TRW. In 1997, Shanghai TRW churned out 239,800 units of seatbelts (from zero in 1996), overtaking Nanjing-Autoliv as the second largest seatbelt manufacturer in the country overnight. It accounted for 60 percent of the seatbelts sourced by SVW in that year. The effect on Nanjing-Autoliv was immediate and devastating. Its output volume plunged from 266,769 units to 132,356 units, creating a great financial distress for the firm. By 1996, the Nanjing-Autoliv had already built capacity sufficient for one million seatbelts and thus Shanghai-TRW created excessive capacity in Nanjing. Switching of suppliers shifted profits from Nanjing to Shanghai. The pre-tax profits per employee at Shanghai TRW was 3,283 yuan in 1997, as compared with only 911 yuan for the Nanjing-Autoliv. In an interview, a TRW manager explained that forming a joint venture with SAIC is the only way to win supply contracts with SVW. The hard edge of SAIC is illustrated by the fact that Shanghai TRW, apparently, is the only joint venture in the world in which TRW has agreed to a less than majority-controlled arrangement.

ZF Friedrichshafen A.G. had a similar experience. ZF, the leading German parts supplier, maintained eight production sites in China. In 1994, ZF signed an agreement with FAW

\footnotetext{
${ }^{89}$ Firm performance data are from (Ministry of Machinery Industry 1997b; State Bureau of Machinery Industry 1998b).
} 
to produce hydraulic steering gears with the intention to supply to the affiliates of Volkswagen in China. The operation ran into difficulties apparently because SAIC refused to source from a facility outside Shanghai and outside SAIC. In 1996, ZF had no choice but to enter into an agreement directly with SAIC to establish a separate joint venture to produce steering systems for Santana. SAIC held 49 percent stake in this joint venture.

\section{Statistical evidence: FIEs in machinery industry}

In the previous section, we showed that appetites for FDI differed among Chinese automotive firms in part because of the different extent they pursued an integration strategy. SAIC embodied such a strategy. It had systematically replaced components imports not only from foreign countries but also from foreign provinces. SAIC relied more heavily on MNCs than BAIC and GAIC because SAIC needed more capital to build its own supplier base rather than continuing with the existing supplier relationships with components firms in other provinces.

The descriptive findings reported in Table 4 are, at best, suggestive rather than conclusive. The descriptive analysis is limited to four observation units and there may be many other differences among them which a case study is unable to control for perfectly. The other issue has to do with the effect of asset fragmentation on FDI. Our hypothesis rests heavily on a distinction between a "build" strategy and an acquisition strategy. Our premise is that a "build" strategy is more expensive than an acquisition strategy in the presence of huge idle capacity and that SAIC and TAIC demanded more FDI in part because they could not acquire assets located in other provinces. The high level of FDI demand on the part of SAIC and TAIC was directly due to their integration strategy in the context of asset fragmentation. But because all four of our firms were locally-controlled firms and they faced similar political constraints in investing outside their provinces, the linkage between the asset fragmentation and FDI demand cannot be directly demonstrated. All we could do was to demonstrate a linkage between pursuing an integration strategy and FDI demand, not a linkage between cross-regional acquisition constraints and FDI demand. A legitimate counterfactual hypothesis is that even if SAIC and TAIC desired to integrate their production, it might not be sufficient to trigger FDI demand. Suppose an acquisition option were available, SAIC and TAIC might have acquired their suppliers as a way to build up their supply capabilities. This would be a cheaper alternative since a substantial overcapacity had been built up in this industry.

${ }^{90}$ See (Wafstyl 1996). 
In this section, we remedy this shortcoming in two ways. First, we rely on a statistical analysis of a moderately large sample size to demonstrate linkages between asset fragmentation and FDI preferences. The data are drawn from China's machinery industry and the dataset consists of 62 units of observations. Although the sample size is only moderately large, it still enables us to control for many firm-level characteristics that may bear on FDI preferences better than even a carefully-designed case study. Second, we attempt to demonstrate the effect of asset fragmentation more directly by comparing FDI preferences of two types of firms. These two types of firms face different constraints on their ability to acquire assets in foreign provinces. By comparing their FDI preferences (while controlling for their other attributes), we are able to demonstrate the effect of asset fragmentation more directly.

As outlined at the beginning of this chapter, there are two broad types of Chinese firms depending on the levels of their administrative affiliations. The first consists of central government firms, i.e., those firms whose control and income rights rest with the central government. Central government firms are freer to invest and to acquire assets cross-regionally because they are not constrained by regional authorities. Also, as our study on FAW shows, it is politically and administratively easier for Beijing to negotiate with a province about asset transfers than it is for a province to negotiate with another province. Thus central government firms are under less pressures to pursue a regional import substitution strategy or are more able to acquire assets across political jurisdictions than locally-controlled firms. This is demonstrated in our examination of FAW earlier in this chapter. FAW operated production throughout the country and it took over many geographically-dispersed facilities in the 1980s and 1990s. Its acquisition attempts were not easy and straightforward, but the important point is that it was at least feasible for FAW to do it. FAW, thus, is said to face less asset fragmentation constraints than firms such as SAIC, BAIC or TAIC. In this section, we present findings from a statistical analysis of the effects on FDI preferences that are associated with the varying constraints of asset segmentation.

Our data are organized at the level of holding firms, all in the machinery industry. The regional holding firms were previously regional bureaus of machinery industry under MMI. During the reform era the regional bureaus became more autonomous and independent from MMI in Beijing and they reported directly to the authorities in their regions. ${ }^{-1}$ Since the mid-

${ }^{91}$ In a few cases, some of the regional bureaus did not report to MMI but to other ministries which also produced lines of machinery products. 
1990s, as a part of the SOE ownership reform program, many of these regional bureaus were converted into holding firms with enhanced power over internal management matters such as rights over asset disposals and transfers within each holding firm. In addition, several independent business units were carved out from a mono-bureaucratic structure. For example, in Tianjin, in 1997, there were four separate holding firms all operating in the machinery industry while in the 1980s all the businesses had been consolidated under one bureau of machinery industry in Tianjin.

The entire machinery industry consists of sixty-two holding firms. Forty-nine are regional; thirteen are central. Central holding firms are much larger than regional holding firms. Table 5 breaks down these sixty two firms by their administrative subordination and presents their various characteristics. Measured in asset and employment terms, central holding firms are about ten times the regional holding firms. On average, an affiliate of a central holding firm has about 1.5 billion yuan in assets and employs over 7,700 persons. In contrast, a regional affiliate only has 143 million yuan in assets and employs 720 persons.

There are numerous affiliates under these holding firms. Although the statistical source does not give a definition of an affiliate, from the profiles of a number of affiliates of SAIC and BAIC, it can be ascertained that an affiliate is a firm that a holding firm either owns wholly or in which it has a partial stake. The partial equity stakes include both majority and minority stakes. Many of these affiliates were factories under the charge of line bureaus of machinery industry or MMI. During the central planning era, they were simply administrative appendices to China's vast industrial bureaucracy. During the reform era, these affiliates became more independent and acquired legal entities separate from their supervisory agencies. They could, for example, negotiate FDI contracts with foreign firms (subject to supervision and approvals of the holding firms) and enter into production and debt contracts with other firms. SVW, for example, is one of the thirty-eight affiliates under SAIC, which is a regional holding firm. Regional holding firms operate numerous affiliates. On average, each regional holding firm operates some 177 affiliates while the central holding firm runs only thirty-eight of them.

Table 5 about here.

Our analysis aims to determine if FDI preferences systematically differ between central and regional holding firms. Our hypothesis is that a central holding firm, all else being equal, has a lower FDI demand because it is able to acquire assets across different regions and has a lesser need to resort to a "build" strategy to integrate its production. A typical central holding firm faces less asset fragmentation constraints as compared to a typical regional holding firm. As 
elsewhere in this book, we measure FDI preferences in terms of foreign equity proportion of FIE affiliates. Foreign equity proportions are the ratios of foreign paid-in capital to the total paid-in capital of a firm. In our dataset, foreign equity proportions represent the cumulative foreign equity claims in the FIE affiliates of the holding firms, not the foreign equity claims of the holding firms. A Chinese investor in a joint venture can be an affiliate of a holding firm or it can be the holding firm itself. Holding firms themselves are not FIEs and they are either owned 100 percent by the state or majority-controlled by the state. FDI contracts were entered into individually and separately with the partnering affiliates or with the holding firms themselves. The holding firms played a critical role in negotiations and set the guideline for FDI negotiations.

Asset fragmentation constraints are operationalized by a dummy variable, central holding firm (CHF). CHF is assigned a value of one when it is a central holding firm and a value of zero in the case of a regional holding firm. Because central holding firms face less asset fragmentation constraints, they should demand less FDI and therefore CHF is expected to be negatively associated with foreign equity proportions. Apart from asset fragmentation constraints, many other factors bear on the equity splits between Chinese and foreign investing firms. For example, foreign control of overseas market channels and marketing expertise is often said to lead to greater foreign equity controls. In order to ascertain the effect of FDI preference, it is necessary to control for the effect of other theoretically-relevant determinants. In our book, these other determining factors mainly serve as controls and we call them control variables. The purpose is to equalize, statistically, the variance along these control variables across different firms in order to isolate the effect of our substantive variable, which is FDI preference in our book.

We offer two models conceptualizing how foreign equity proportions are determined. (The appendix to this chapter offers a more detailed explanation.) The first model is very simple: It assumes that foreign equity proportions are a function of the level of FDI inflows. The larger FDI inflows are, the larger foreign equity proportions are. The aim here is to see if asset fragmentation constraints exert any additional influences on foreign equity proportions once the effect of FDI levels is fully taken into account. The idea behind this conceptualization is that the realized FDI flows already incorporated all the theoretically-relevant determinants of foreign equity proportion. Since we only have a partial or imprecise knowledge of what those determinants are we opt to use a proxy variable that incorporates the effect of all the determinants combined. Because our dependent variable refers to foreign equity proportion at the 
level of affiliates, we use the average FDI per affiliate in our analysis (abbreviated as FDIPA in Table 6. 2.

Our other model spells out some of the theoretically-relevant control variables explicitly and includes them in lieu of FDI levels in the statistical analysis. The appendix provides more details explaining both the rationale behind our specification as well as the operationalization of the variables. Suffice it to say that our specification is guided in part by the industrial organization (IO) conceptions of FDI determination. However, there are a number of differences with the IO theory that should be explicitly noted. One difference is that the standard approach typically examines factors influencing distribution of FDI across different industries whereas our study focuses on the distribution of equity shares across different firms within the same industry. But machinery industry is very broad and encompasses many products with different technological characteristics. The approach may make sense if, for example, firms specialize in particular industry segments. In addition, the IO conceptualization has been extended to the firmlevel data by other researchers who are interested in studying bargaining dynamics between MNCs and host governments and firms. Such an extension has proven to be highly fruitful in guiding the basic research design. ${ }^{93}$ The bigger difference has to do with the analytical purpose of our inquiry. As I carefully set out from the very beginning of this book, my interest is to study Chinese demand for FDI, not so much foreign supply of FDI. In a real world, obviously, demand factors intersect with supply factors to produce the actual outcome. Thus in order to assess the effect of those demand factors accurately, it is necessary to control for those factors that affect the supply side. These IO variables mainly serve this purpose in our analysis. Third, it should be stressed that the IO variables in our study serve as control variables. Unlike most of the studies in the IO literature, these variables themselves are not the main subject of our inquiry. Our analytical interest is to understand how asset fragmentation constraints may or may not affect FDI preferences.

There are four control variables based roughly on an IO perspective on FDI. They are: foreign marketing control (FMC), the average asset size per affiliate (AAPA), R\&D expenditures of holding firms (R\&DE), and the proportion of the largest affiliates (PLA). These four variables are intended to capture the gist of the IO perspective that FDI is a function of market power and specialized know-how on the part of MNCs. However, our own specification differs from the

\footnotetext{
${ }^{92}$ For methodological reasons, we use the logged values of FDIPA in the statistical analysis.

${ }^{93}$ See, for example, (Gomes-Casseres 1990) and (Krobin 1987).
} 
standard approach. All our data are based on the IO characteristics of Chinese firms, rather than the IO characteristics of foreign investing firms. The standard approach is to use the IO characteristics of foreign investing firms as those supply factors affecting FDI but because of the data limitations, this is infeasible. It is reasonable to expect that the IO characteristics of the Chinese firms may correlate strongly with the IO characteristics of foreign firms. Take industry concentration as an example. While institutional factors, as shown in this chapter, affect the extent of such IO characteristics as industry concentration within an industry, they do not change the rank order of industry concentration across industries. Chinese automotive industry is less concentrated than it is elsewhere but it is one of the most concentrated industries in China.

FMC is operationalized by the export shares of production of a holding firm. The more export a firm produces, the more foreign marketing control an MNC exercises. More FMC is one of the advantages held by MNCs and should lead to greater foreign equity controls. R\&DE is measured as the ratios of R\&D expenditures to sales in a holding firm. MNCs excel in the R\&D intensive activities and thus they should enjoy advantages in technologically-intensive areas when they negotiate with Chinese firms. R\&DE should be associated positively with foreign equity proportion. AAPA is the average asset size per affiliate within a holding firm. Large asset size is typically associated with market power and thus confers more advantages on investing MNCs. It should be positively correlated with foreign equity proportion. ${ }^{94}$ Finally, the presence of very large firms is used to measure the degree of entry barriers in a particular industry or industry segment. MNCs, according to the IO theory, enjoy advantages in industries with entry barriers.

The appendix discusses other renditions of the statistical methods and presents results from alternative operalizations of both dependent and independent variables. The appendix also discusses the problems that arise when the control variables themselves are caused by our dependent variable. Thus the causal connection may go from foreign equity controls to some of our control variables, rather than the other way around. (This is called an endogeneity problem.) While this problem casts into doubt interpretations of some of the control variables, it is important to point out and stress that there is no question as to the causal direction of our substantive variable, CHF. The purpose of including the control variables is to impose a ceteris paribus condition despite the fact that the underlying causal mechanism of these control variables may be misspecfied.

\footnotetext{
${ }^{94}$ For methodological reasons, the logged version of AAS is used in the regression analysis.
} 
Table 6 presents results from our simple model in which the only control variable is the FDI level. Five versions of this model are run, using Ordinary Least Squares (OLS) regression technique ${ }^{65}$ The dependent variable is the foreign equity ratio given by the ratio of foreign equity to the total paid-in equity capital of a holding firm. In the first version, only CHF and FDIPA are included and in other versions, additional control variables are added one by one to the analysis. In all versions, the level of FDI, i.e., FDIPA, is positively associated with FER at a statistically significant level, providing evidence for the unsurprising proposition that more FDI inflows do contribute to greater equity controls by the MNCs. However, FDIPA is not the only influence on FER; in Table 6 the dummy variable for central holding firms, CHF, is consistently negative and statistically significant. The coefficient ranges from -0.044 to -0.051 . This means a typical central holding firm has a smaller FER compared to a typical regional holding firm in the order of 0.044 to 0.051 after the level of their FDI inflows is equalized. To put it another way, the same amount of FDI inflows generates a smaller degree of foreign ownership among central holding firms as compared to regional holding firms. This is prima facie that regional holding firms made larger equity concessions to MNCs than did central holding firms.

Table 6 about here.

To be sure there may be other differences between a central and regional holding firm other than their FDI preference that may lead to this outcome. For example, in automotive industry, regional holding firms such as SAIC and GAIC are all located in the coastal provinces whereas central holding firms such as Dongfeng Motor Corporation are in the interior province of Hubei. FAW is located in Jilin province, hardly a magnet for FDI. This locational difference may have an effect on FER because policies and regulations on FDI tend to be more liberal in coastal provinces than in interior provinces. Another possibility is that the central government protects its own firms from foreign encroachment more than it does for regional firms. The central government has a greater equity stake in central holding firms than in regional holding firms and it may restrict foreign ownership in order not to dilute its own equity shares. 6 While this is germane to the FDI preference question, the difference in the FDI preference, however, arises from a different mechanism than asset fragmentation. Finally, Chinese firms-and SOEs in particular-carry a heavy load of social liability such as pension payments to the retired

\footnotetext{
95 The appendix discusses the results from Generalized Least Squares technique and the results are consistent with the ones from OLS.

${ }^{96}$ On average, the state equity share of the Chinese portion of the paid-in equity capital is 73.4 percent for the central holding firms and 53 percent for the regional holding firms.
} 
workers and provision of social welfare functions. Social liability may deter FDI, which should be captured by the FDIPA variable, but it may also weaken the bargaining position of the Chinese firms. To the extent that central holding firms may have a lower level of social liability than regional holding firms, they may gain bargaining power vis-à-vis MNCs, not because they face less asset fragmentation constraints.

In Table 6 versions two to four of Model One incorporate these three variables into the regression analysis. Coastal effect (COAST) is a dummy variable with a value of one for holding firms located in coastal provinces and a value of zero for those in the interior provinces. The state equity ratio (SER) is the ratio of state equity stake to the Chinese portion of the total paid-in equity capital of a holding firm. 8 Social liability ratio (SLR) is calculated as the ratio of nonproduction fixed assets of a holding firm to its total fixed assets. Non-production fixed assets are assets that appear on a firm's balance sheet but do not generate any cash flows. Examples of such assets include employee housing, communal bath and dinning facilities, schools, and health care facilities, etc. If these three variables better explain the seemingly lower FDI demand on the part of central holding firms, including them in the regression analysis should either weaken or make CHF effect go away. However, this did not happen. In Table 6. CHF continues to be statistically significant and the sign remains negative even after all three other control variables are added. This is an indication that the FDI-suppressant effect of the CHF is not explained by the alternative theories why central holding firms may enjoy a bargaining edge over regional holding firms vis-à-vis MNCs.

Table 7 presents an alternative model of determinants of foreign equity proportion, using explicit measures of those factors that purportedly affect FDI flows. Thus Model Two differs

${ }^{97}$ Central holding firms hold a slightly lower social liability ratio as defined in this book, i.e., the ratio of non-production fixed assets to the total fixed assets. Their ratio is 23.1 percent while the regional holding firms have a ratio of 24.3 percent.

${ }^{98}$ It is necessary to exclude foreign equity from the calculation of this variable because otherwise the FER and SER would have the same denominator and their correlation is essentially a mathematical relationship, i.e., a greater value of SER would necessarily be associated with a lesser value of FER. There is also a substantive reason to include the Chinese portion of the total paid-in equity capital in the calculation of SER. Since the Chinese state has carefully excluded Chinese private firms from the machinery industry while actively courting FDI, it may be more accurate to say that the central government is more concerned about dilution of its shares in the Chinese portion of the equity stake, rather than the entire equity stake of a firm. 
from Model One by substituting FDIPA with four variables that IO literature views as important influences on FDI flows and, in the extensions of the IO perspective to firm-level studies, as important influences on bargaining power of MNCs. Two of these four variables, FMC and AAPA, are statistically significant and acquire a positive sign consistent with the IO perspective on FDI. The other two variables, however, fail to attain statistical significance and one of them, PLF, produces a negative coefficient, contrary to the prediction of the IO theory. Our substantive variable, CHF, however remains statistically significant and retains the negative sign across the four versions of Model Two, thus providing further proof that our conception of FDI preference is robust to the various specifications about the determinants of foreign equity proportion.

Table 7 here.

\section{Conclusion}

Economic fragmentation has never been an intention on the part of China's central policy makers. Speaking in 1984, Deng Xiaoping declared, "Invigoration of the domestic economy also means opening the domestic economy. There are, in fact, two open policies: open to the outside world and open to the inside." The Chinese policy makers have been consistent in stressing both external and internal openings and throughout the 1980s the central government issued instructions to local authorities to "unclog the channels of circulation," to "smash blockades." In 1991, Hu Ping, the then Minister of Commerce, reiterated the importance of the twin openings to the world and internal markets. 99 The reality, as carefully laid out in this chapter, has sharply diverged from the original policy intentions. One straightforward measure is that while foreign trade-i.e., export plus import—as a share of GDP has risen during the reform era, interprovincial trade as a share of provincial GDP has shrunk and in many provinces it has shrunk dramatically. The economic fragmentation has not only occurred on the product market but it has been accentuated on the asset market. Immobility of goods is reinforced by the immobility of capital.

In the history of China's planned economy, economic centralization has been a sporadic response to what has been viewed as excessive decentralization. In other words, decentralization has always been the reigning principle of China's economic organization, not centralization. But China's decentralization is of an overwhelmingly administrative kind, i.e., the central

\footnotetext{
${ }^{99}$ Deng's quote and Minister Hu's reiteration of the twin openings are recounted in (Wedeman
} 2000), p. 25. 
government has delegated many economic responsibilities_-including running, operating and collecting taxes from firms - to lower-level authorities. The administrative decentralization ought to be distinguished from economic decentralization-defined here as moving economic responsibilities out of governmental sphere and into the hands of private hands. That China has chosen administrative over economic decentralization is no accident; it is a function of the fact that the government has steadfastly and stubbornly refused to adopt a privatization stance. Administrative decentralization, thus, is an efficiency-enhancing device given that true economic decentralization is precluded as a politically viable solution to many of the problems in a socialist economy.

Economic fragmentation holds important implications for the roles and functions of FDI. Economic fragmentation costs capital and those regional governments deeply in pursuit of an import substitution strategy needed to import capital somewhere. Asset fragmentation, however, essentially means that cross-regional capital mobility is low for domestic firms and FDI rises to fulfil this unsatisfied need. This is the basic logic behind our hypothesis that economic fragmentation raises China's demand for FDI. Or put it another way, the higher demand for FDI prompts regional governments to pay a higher price for it—by ceding more controls over assets than otherwise would be the case. This chapter provides considerable amount of evidence documenting the degree of economic fragmentation, the extent of import substitution strategies at the regional level, and the effect on FDI demand on the part of Chinese firms.

Throughout this book, we have argued that a high portion of FDI inflows into China is induced by the way Chinese economic and financial institutions are designed. Fragmentationinduced FDI has as a firm institutional grounding as our two other institutional sources of FDIinsolvency of the state sector and liquidity constraints of private firms. The reason is that economic fragmentation is not just a function of configuring and reconfiguring resources and power between central government and regional governments but is fundamentally rooted in the state ownership. To that extent, we argue that fragmentation-induced FDI is ultimately rooted in state ownership — the institutional foundation of China's half-reformed economy. 


\section{Appendix}

\section{Sources of data}

The main source of data is (State Bureau of Machinery Industry 1998a). This is the most comprehensive and most detailed collection of industry and firm data among all the available sources. Each year firms in China are required to fill out detailed informational forms to be submitted to their supervisory agencies. The data contained in (State Bureau of Machinery Industry 1998a) were aggregated by the State Bureau of Machinery Industry from all the provinces and all the central government firms under its jurisdiction. The source contains detailed balance sheet and income statement data as well as physical data on output, units of equipment, employment, etc. The data are also much more disaggregated than the usual statistical sources such as Chinese Statistical Yearbook or Chinese Industry Yearbook. This level of disaggregation permits a researcher to undertake the kind of detailed statistical analysis as undertaken here.

\section{Definitions of variables}

Our dependent variable is the proportion of equity stakes held by foreign companies and it is calculated by taking the ratio of foreign equity to total paid-in equity capital of a firm. The equity stakes refer to registered equity capital, i.e., the amount of equity capital a firm has when it registers itself with the State Bureau of Commerce and Industry. It is otherwise known as paidin equity capital and the equity splits between Chinese and foreign firms are at the time of registration. Subsequently, a firm may elect to change its equity split, which requires approval from the Chinese government. The reason that we use foreign equity proportion at the time of registration is that it best reflects the bargaining positions of Chinese and foreign firms at the time they negotiate the joint venture formation. Just to make sure, I have also run all the regression analyses in this chapter on the actual foreign equity proportion at the time the data were collected. The results are not different from using paid-in equity data.

Our substantive variable is a dummy variable with the value of one for central holding firms and the value of zero for regional holding firms. It is abbreviated as CHF in the text. The control variable in Model One is FDI per affiliate (FDIPA), which is simply the amount of foreign equity capital in a holding firm divided by the number of its affiliates. In all the 
regression runs, FDIPA is transformed by taking logs. This is done to remove the non-linearity in this variable.

Four control variables appear in Model Two. Foreign marketing control (FMC) is denoted by the proportion of the industrial output value that is exported. R\&D expenditure $(R \& D E)$ is the ratio of $R \& D$ expenditure to sales of a holding firm. Average asset per affiliate (AAPA) refers to the asset of a holding firm divided by the number of affiliates within a holding firm. Like FDIPA, this variable is log transformed to remove the non-linearity in it. Proportion of largest firms (PLF) is the proportion of affiliates with a production-related fixed asset in excess of 50 million yuan within a holding firm. The statistical source gives the number of affiliates for seven categories broken down by the size of the production-related fixed asset: 1) below 1 million yuan, 2) between 1 and 5 million yuan, 3) between 5 and 10 million yuan, 4) between 10 million to 30 million yuan, 5) between 30 million and 50 million yuan, 6) between 50 and 100 million yuan and 7) above 100 million yuan. The largest firm here is defined as one in excess of 50 million yuan in production-related fixe assets.

Other control variables are COAST, state equity ratio (SER), and social liability ratio (SLR). COAST is a dummy variable with the value of one for all the holding firms located in coastal provinces and the value of zero for those located in the non-coastal provinces. SER is given by dividing the state equity by the Chinese portion of the paid-in equity capital of a holding firm. The Chinese portion of the paid-in equity capital is derived by subtracting the foreign equity capital from the total paid-in equity capital. SLR is given by dividing the non-production fixed assets of a holding firm by its total fixed assets. Both fixed asset figures are given as their original cost values.

Table 8 presents descriptive statistics on the main variables used in the analysis. Table 8 about here.

\section{Model specifications}

Model Two is guided by the theoretical accounts in the economics literature on FDI determinants. By far, the dominant account of the cross-industry FDI distribution is the industrial organization (IO) explanation. The IO reasoning hinges on the notion that FDI, fundamentally, reflects the ability of profit-maximizing MNCs to overcome market imperfections. The starting 
point of the IO reasoning is that foreign firms incur costs that domestic firms do not. ${ }^{00}$ These costs range from the intrinsic difficulties of managing cross-border operations to the costs of gathering information and developing expertise about foreign markets, political, social and legal environments, etc. Political uncertainty also abounds in investing overseas. Much of these costs is large, fixed and up-front. To offset these extra costs, a foreign firm must possess internal, ownership-specific advantages over its domestic rival firms. These advantages take the form of R\&D capabilities, managerial know-how, organizational skills, marketing expertise, and economies of scale, etc. Further, the idea that these advantages must be firm-specific is central to the IO perspective. These advantages are available to the MNCs, but not to others due to the structural impediments. The clearest examples here would be patent protection and brand name that yield rents to their holders.

The spirit of the IO explanation dictates that the inter-industry distribution of FDI be modeled as a function of the following characteristics of an industry: the degree of product differentiation, level of competition, scale economies, and research and development (R\&D) intensity. MNCs are hypothesized to be more prevalent in those industries that are characterized by a significant degree of product differentiation, high concentration ratios, scale economies and deep R\&D expenditures due to their superior market power over their domestic rivals. In general, IO-motivated research on inter-industry distribution of FDI in more developed economies such as Canada and United Kingdoms has received more empirical validation than similar research on FDI in developing economies.

As noted in the text, our control variables suffer from what is known as an "endogeneity problem," i.e., while our model assumes that the causal direction runs from these control variables to the FER it may very well be the case that FER is a cause of our control variables. For example, one can plausibly argue that higher values of FER should lead to higher values of FDIPA, not the other way around. MNCs, for example, may demand controlling equity stakes and short of controlling equity stakes FDI may not materialize.

100 The pioneering work in this field is (Hymer 1976 ). For a good summary of this large body of literature, see(Caves 1996) and (Lizondo 1995). For a good summary with specific references to developing countries, see (Lall 1978) and (De Mello 1997).

${ }^{101}$ For a sample of empirical work on the inter-industry determination of FDI distribution, see (Caves 1974), (Orr 1974) and (Meredith 1984), which in general provided support for the IO postulates. In contrast, (Aswicahyono and Hill 1995) only found mixed evidence for the IO theory. 
The nature of the inquiry makes it very difficult to completely rid of the endogeneity problem. Our primary concern, however, is whether the statistical significance and the sign of our substantive variable, $\mathrm{CHF}$, are somewhat affected by this endogeneity problem. On an $a$ priori basis, there is no reason that $\mathrm{CHF}$ should be affected one way or the other (and CHF itself, for sure, does not suffer from endogeneity problem). Just to make sure, I have relied on alternative dependent variables which may attenuate, although not remove, the endogeneity problem. One way is to lag the independent variables so that the values of independent and dependent variables are not contemporaneous. We have the data on FER for 1998 and thus I have regressed the FER for 1998 on the same independent variables in Models One and Two. The results are not different. Of course, this does not really deal with the endogeneity problem since the 1998 values of the independent variables are surely highly correlated with the 1997 values of the independent variables. Instead, I used the ratio of the 1998 foreign equity capital to the 1997 foreign equity capital as the dependent variable. CHF is negative in both Models One and Two but it is only significant in Model One (at -0.548 with a standard error of 0.239 ). Thus there is some evidence that CHF deters FDI growth from 1997 to 1998 . This does not really get to the heart of our question, which is about foreign ownership control. The dependent variable thus formulated is about the growth of FDI from 1997 to 1998.

Our data structure is cross-sectional and in a cross-sectional data structure one of the assumptions for OLS analysis may be violated and this has to do with the assumption that the distribution of the dependent variable has the same spread. To remedy this problem, statistical researchers use a technique called Generalized Least Squares (GLS). I have used GLS technique for all our specifications and the sign and the statistical significance of CHF remain unaffected. 
Table 1 Concentration Ratios of the Automotive Industry: Four-Country Comparison (\%)

\begin{tabular}{lllll}
\hline & One-Firm Ratio & Two-Firm Ratio & $\begin{array}{l}\text { Three-Firm } \\
\text { Ratio }\end{array}$ & $\begin{array}{l}\text { Market Size } \\
\text { (Million) }\end{array}$ \\
\hline Brazil: & & & & \\
1959 & 24.8 & 42.7 & 60.6 & $0.42^{*}$ \\
1970 & 56.1 & 74.3 & 91.2 & 0.41 \\
Japan: & & & & 6.94 \\
1960 & 32.1 & 56.1 & 65.1 & \\
1975 & 33.7 & 63.6 & 72.8 & \\
Korea: & & & & \\
1975 & 54.6 & 77.7 & 96.4 & \\
1986 & 71.3 & 88.6 & 97.9 & 1.07 \\
China: & & & & 1.29 \\
1985 & 19.2 & 38.0 & 43.0 & 1.16 \\
1992 & 13.1 & 26.0 & 32.1 & 1.28 \\
1993 & 13.7 & 25.2 & 34.0 & 1.41 \\
1994 & 13.5 & 26.6 & 35.7 & 1.57 \\
1995 & 12.6 & 23.6 & 33.3 & 1.60 \\
1996 & 13.9 & 27.5 & 37.8 & \\
1997 & 14.6 & 25.6 & 35.6 & 34.4 \\
1998 & 14.7 & 25.4 & & \\
\hline
\end{tabular}

Note:

*: Production figure.

Sources: Data on Brazil, Japan, and Korea are calculated from World Motor Vehicle Data and Ward's Automotive Yearbook, various issues. Data on China are calculated from China Automotive Yearbook, various issues. 
Table 2 A tale of two firms: SAIC and BAIC, 1990 and 1997

\begin{tabular}{lll}
\hline & SAIC & BAIC \\
\hline Size (RMB million) & & \\
Sales revenue & & \\
1990 & 3,605 & 4,1214 \\
1997 & $40,394.6$ & $8,873.6$ \\
& & \\
Assets* & & \\
1990 & $2,048.9$ & 1,428 \\
1997 & $26,545.5$ & $8,526.1$ \\
Financial ratios (\%) & & \\
Gross margins** & & \\
1990 & 9.57 & 7.11 \\
1997 & 13.73 & -2.17 \\
Technological intensity $(\%)$ & & \\
Technicians/Workers & & \\
1990 & 14.7 & 25.9 \\
1997 & 16.0 & 11.3 \\
\hline
\end{tabular}

Notes: $*$ Assets $=$ Net fixed assets + current assets.

**: Gross margins $=$ Pre-tax profits/sales revenues. 
Table 3 FAW and SAIC compared, 1997

\begin{tabular}{lll}
\hline & FAW & SAIC \\
\hline Subordinate to: & MMI in Beijing & Shanghai city \\
Assets & 59.82 billion yuan & 36.19 billion yuan \\
Sales & 34.11 billion yuan & 40.39 billion yuan \\
Profits & 570.4 million yuan & 5.54 billion yuan \\
Employment & 173,043 persons & 61,672 persons \\
Vehicle output & 268,868 units & 232,074 units \\
Number of affiliates & 20 & 38 \\
Number of affiliates located outside home provinces & 14 & 0 \\
\hline
\end{tabular}

Note: MMI stands for Ministry of Machinery Industry. Affiliate is defined as a firm in which FAW or SAIC has a substantial equity interest (usually above 50 percent).

Source: (Ministry of Machinery Industry 1998). 
Table 4 Four automotive business groups compared: Integration strategy, performance and FIE characteristics, various years

\begin{tabular}{|c|c|c|c|c|c|c|c|c|c|c|c|}
\hline \multirow{3}{*}{$\begin{array}{l}\text { Firms }^{\mathrm{a}} \\
\\
\text { Year }\end{array}$} & \multicolumn{3}{|c|}{$\begin{array}{l}\text { Components production as shares of : } \\
(\%)^{\mathrm{b}}\end{array}$} & \multicolumn{4}{|c|}{ Various performance measures } & \multicolumn{4}{|c|}{ FIE characteristics } \\
\hline & \multicolumn{2}{|c|}{ Output value } & $\begin{array}{l}\text { New fixed } \\
\text { asset } \\
\text { investments }\end{array}$ & \multicolumn{2}{|c|}{$\begin{array}{l}\text { Returns on assets, } \\
(\%)^{\mathrm{d}}\end{array}$} & \multirow{2}{*}{$\begin{array}{l}\text { Localizatio } \\
n \text { ratios }^{\mathrm{e}}\end{array}$} & \multirow{2}{*}{$\begin{array}{l}\begin{array}{l}\text { Output } \\
\text { volume }\end{array} \\
1996\end{array}$} & \multirow{2}{*}{$\begin{array}{l}\begin{array}{l}\text { Number of } \\
\text { FIEs } \\
\text { established }\end{array} \\
1983-1997\end{array}$} & \multirow{2}{*}{$\begin{array}{l}\text { Average size of } \\
\text { paid-in capital per } \\
\text { FIE ( } \$ \text { million) } \\
1983-1997\end{array}$} & \multicolumn{2}{|c|}{$\begin{array}{l}\text { Average foreign equity } \\
\text { share of total paid-in } \\
\text { capital, }(\%)\end{array}$} \\
\hline & 1992 & 1997 & 1997 & 1992 & 1998 & & & & & $\begin{array}{l}1983- \\
1997\end{array}$ & $1990 \mathrm{~s}$ \\
\hline$\underline{\text { SAIC }}$ & 17.8 & 27.0 & 81.1 & 27.2 & 14.9 & 90.45 & 200,222 & 29 & 40.9 & 47.4 & 48.3 \\
\hline$\underline{\text { TAIC }}$ & 14.3 & 30.5 & 63.7 & 29.8 & 1.43 & 93.29 & 88,000 & 25 & 20.6 & 53.3 & 53.1 \\
\hline$\underline{\text { GAIC }}$ & $0.0^{\mathrm{c}}$ & $5.6^{\mathrm{c}}$ & $10.0^{\mathrm{c}}$ & $10.4^{\mathrm{c}}$ & $-3.64^{\mathrm{c}}$ & 85.3 & 2,544 & 42 & 10.6 & $\begin{array}{l}49.6 \\
(47.1)^{\mathrm{g}}\end{array}$ & 49.2 \\
\hline
\end{tabular}

Notes:

a: SAIC: Shanghai Automotive Industry Corporation. TAIC: Tianjin Automotive Industry Corporation. BAIC: Beijing Automotive Industry Corporation. GAIC: Guangdong Automotive Industry Corporation.

b: Components include engines, but not chassis.

c: Data on GAIC are not available. The data presented in the table refer to Guangzhou city. 
d: Returns on assets are given by: Pre-tax profits divided by the sum of net fixed assets and current assets. Pre-tax profits are used because tax rates often differ among firms.

e: Localization ratios are measured in quantity rather than in value terms. The figures cover passenger car vehicles only. The passenger cars being measured are: Santana (SAIC), Charade TJ7100 (TAIC), Cherokee BJ2021 (BAIC), and Peugeot (GAIC).

${ }_{\text {f: }}$ Output volume refers to passenger cars only.

g: Figures in the bracket do not include two wholly-owned FIEs.

Sources: Information on FIEs is from (Zhang Xiaoyu 1998). Localization, output and profitability data are from (Ministry of Machinery Industry 1993) and (Ministry of Machinery Industry 1997a). 
Table 5 Basic characterstics of central and local holding firms in China's machinery industry, 1997

\begin{tabular}{|c|c|c|c|c|c|}
\hline & $\begin{array}{l}\text { Number of } \\
\text { holding firms }\end{array}$ & $\begin{array}{l}\text { Average } \\
\text { number of } \\
\text { affiliates per } \\
\text { holding firm }\end{array}$ & $\begin{array}{l}\text { Average } \\
\text { foreign } \\
\text { equity } \\
\text { proportion of } \\
\text { affiliates per } \\
\text { holding firm }\end{array}$ & $\begin{array}{l}\text { Average } \\
\text { assets per } \\
\text { affiliate }\end{array}$ & $\begin{array}{l}\text { Average } \\
\text { employment } \\
\text { per affiliate }\end{array}$ \\
\hline $\begin{array}{l}\text { Central } \\
\text { holding firms }\end{array}$ & 13 & 38.5 & $9.08 \%$ & $\begin{array}{l}1.53 \text { billion } \\
\text { yuan }\end{array}$ & $\begin{array}{l}7,721 \\
\text { persons }\end{array}$ \\
\hline $\begin{array}{l}\text { Local } \\
\text { holding firms }\end{array}$ & 49 & 177 & $12.65 \%$ & $\begin{array}{l}143.8 \text { million } \\
\text { yuan }\end{array}$ & 720 persons \\
\hline
\end{tabular}

Note:

Source: Based on (State Bureau of Machinery Industry 1998a). 
Table 6 Ordinary least squares regression analysis of foreign equity proportion in the machinery industry: Model 1

\begin{tabular}{|c|c|c|c|c|}
\hline \multicolumn{5}{|c|}{ Dependent variable: Foreign equity ratio (FER=foreign equity divided by the total paid-in capital) } \\
\hline $\begin{array}{l}\text { Substantive } \\
\text { variable: }\end{array}$ & (1) & $(2)$ & (3) & $(4)$ \\
\hline $\begin{array}{l}\text { Central holding } \\
\text { firm dummy } \\
\text { (CHF) }\end{array}$ & $\begin{array}{l}-0.051^{*} \\
(0.026)\end{array}$ & $\begin{array}{l}-0.044^{*} \\
(0.025)\end{array}$ & $\begin{array}{l}-0.044^{*} \\
(0.026)\end{array}$ & $\begin{array}{l}-0.045^{*} \\
(0.0255)\end{array}$ \\
\hline \multicolumn{5}{|l|}{ Control variables: } \\
\hline $\begin{array}{l}\text { FDI per affiliate } \\
\text { (FDIPA) }\end{array}$ & $\begin{array}{l}0.034 * \\
(0.04)\end{array}$ & $\begin{array}{l}0.031^{*} \\
(0.004)\end{array}$ & $\begin{array}{l}0.031^{*} \\
(0.004)\end{array}$ & $\begin{array}{l}0.029^{*} \\
(0.004)\end{array}$ \\
\hline \multicolumn{5}{|l|}{$\begin{array}{l}\text { Other control } \\
\text { variables: }\end{array}$} \\
\hline $\begin{array}{l}\text { Coastal effect } \\
\text { (COAST) }\end{array}$ & & $\begin{array}{l}0.061^{*} \\
(0.0315) \\
\end{array}$ & $\begin{array}{l}0.0476^{* *} \\
(0.035)\end{array}$ & $\begin{array}{l}0.045^{* *} \\
(0.035) \\
\end{array}$ \\
\hline $\begin{array}{l}\text { State equity ratio } \\
\text { (SER) }\end{array}$ & & & $\begin{array}{l}-0.0485 \\
(0.055) \\
\end{array}$ & $\begin{array}{l}-0.042 \\
(0.055)\end{array}$ \\
\hline $\begin{array}{l}\text { Social liability } \\
\text { ratio (SLR) }\end{array}$ & & & & $\begin{array}{l}-0.159 \\
(0.134)\end{array}$ \\
\hline Constant & $\begin{array}{l}-0.025 \\
(0.021)\end{array}$ & $\begin{array}{l}-0.026 \\
(0.021)\end{array}$ & $\begin{array}{l}0.014 \\
(0.049)\end{array}$ & $\begin{array}{l}0.058 \\
(0.061)\end{array}$ \\
\hline F-statistic & $37.85^{*}$ & $27.68 *$ & $20.88^{*}$ & $17.1^{*}$ \\
\hline $\begin{array}{l}\text { Number of } \\
\text { observation }\end{array}$ & 62 & 62 & 62 & 62 \\
\hline Adjusted $\mathrm{R}^{2}$ & 0.547 & 0.568 & 0.566 & 0.569 \\
\hline
\end{tabular}

Note:

*: Significant at 0.05 .

**: Significant at 0.10 .

Variable definitions:

1) Central holding firm (CHF): $\mathrm{CHF}$ is a dummy variable with one for central holding firms and zero for regional holding firms.

2) FDI per affiliate (FDIPA): FDIPA is given by dividing foreign equity capital of a holding firm by the number of affiliates within that holding firm. The logged value of FDIPA is used in the statistical analysis.

3) Coastal effect (COAST): COAST is a dummy variable with the value of one for all the holding firms located in coastal provinces and the value of zero for those located in the noncoastal provinces.

4) State equity ratio (SER): SER is given by dividing the state equity by the Chinese paid-in equity capital of a holding firm. The Chinese portion of the paid-in equity capital is derived by subtracting the foreign equity capital from the total paid-in equity capital.

5) Social liability ratio (SLR): SLR is given by dividing the non-production fixed assets of a holding firm by its total fixed assets. Both fixed asset figures are given as their original cost values. 
Table 7 OLS regression analysis of foreign equity proportion in the machinery

\section{industry: Model 2}

\begin{tabular}{|c|c|c|c|c|}
\hline \multicolumn{5}{|c|}{ Dependent variable: Foreign equity ratio (FER=foreign equity divided by the total paid-in capital) } \\
\hline $\begin{array}{l}\text { Substantive } \\
\text { variable: }\end{array}$ & (1) & (2) & (3) & $(4)$ \\
\hline $\begin{array}{l}\text { Central holding } \\
\text { firm dummy } \\
\text { (CHF) }\end{array}$ & $\begin{array}{l}-0.092 * \\
(0.054)\end{array}$ & $\begin{array}{l}-0.086^{* *} \\
(0.052)\end{array}$ & $\begin{array}{l}-0.085^{*} \\
(0.049)\end{array}$ & $\begin{array}{l}-0.077 * * \\
(0.049)\end{array}$ \\
\hline \multicolumn{5}{|l|}{ Control variables: } \\
\hline $\begin{array}{l}\text { Foreign marketing } \\
\text { control (FMC) }\end{array}$ & $\begin{array}{l}0.485^{*} \\
(0.143) \\
\end{array}$ & $\begin{array}{l}0.432^{*} \\
(0.14) \\
\end{array}$ & $\begin{array}{l}0.415^{*} \\
(0.134)\end{array}$ & $\begin{array}{l}0.346^{*} \\
(0.136) \\
\end{array}$ \\
\hline $\begin{array}{l}\text { R\&D expenditure } \\
\text { (R\&DE) }\end{array}$ & $\begin{array}{l}0.449 \\
(0.558) \\
\end{array}$ & $\begin{array}{l}0.355 \\
(0.54) \\
\end{array}$ & $\begin{array}{l}0.494 \\
(0.518) \\
\end{array}$ & $\begin{array}{l}0.30 \\
(0.515) \\
\end{array}$ \\
\hline $\begin{array}{l}\text { Average asset per } \\
\text { affiliate (AAPA) }\end{array}$ & $\begin{array}{l}0.047 * \\
(0.021) \\
\end{array}$ & $\begin{array}{l}0.041 * \\
(0.021) \\
\end{array}$ & $\begin{array}{l}0.043^{*} \\
(0.019) \\
\end{array}$ & $\begin{array}{l}0.033 * * \\
(0.019) \\
\end{array}$ \\
\hline $\begin{array}{l}\text { Proportion of } \\
\text { largest firms (PLF) }\end{array}$ & $\begin{array}{l}-0.062 \\
(0.089) \\
\end{array}$ & $\begin{array}{l}-0.039 \\
(0.086) \\
\end{array}$ & $\begin{array}{l}-0.036 \\
(0.082) \\
\end{array}$ & $\begin{array}{l}-0.026 \\
(0.081) \\
\end{array}$ \\
\hline \multicolumn{5}{|l|}{$\begin{array}{l}\text { Other control } \\
\text { variables: }\end{array}$} \\
\hline $\begin{array}{l}\text { Coastal effect } \\
(\text { COAST })\end{array}$ & & $\begin{array}{l}0.096^{*} \\
(0.0427) \\
\end{array}$ & $\begin{array}{l}0.040 \\
(0.046)\end{array}$ & $\begin{array}{l}0.039 \\
(0.045)\end{array}$ \\
\hline $\begin{array}{l}\text { State equity ratio } \\
\text { (SER) }\end{array}$ & & & $\begin{array}{l}-0.172^{*} \\
(0.068) \\
\end{array}$ & $\begin{array}{l}-0.141^{*} \\
(0.068) \\
\end{array}$ \\
\hline $\begin{array}{l}\text { Social liability } \\
\text { ratio (SLR) }\end{array}$ & & & & $\begin{array}{l}-0.329 * \\
(0.169) \\
\end{array}$ \\
\hline Constant & $\begin{array}{l}-0.35^{* * *} \\
(0.192) \\
\end{array}$ & $\begin{array}{l}-0.308 \\
(0.186) \\
\end{array}$ & $\begin{array}{l}-0.20 \\
(0.18) \\
\end{array}$ & $\begin{array}{l}-0.04 \\
(0.19) \\
\end{array}$ \\
\hline F-statistic & $2.94 *$ & $3.43 * *$ & $4.16^{*}$ & 4.3 \\
\hline $\begin{array}{l}\text { Number of } \\
\text { observation }\end{array}$ & 62 & 62 & 62 & 62 \\
\hline Adjusted $\mathrm{R}^{2}$ & 0.137 & 0.195 & 0.266 & 0.30 \\
\hline
\end{tabular}

Note:

*: Significant at 0.05 .

**: significant at 0.10 .

Variable definitions:

1) Central holding firm $(\mathrm{CHF})$ : $\mathrm{CHF}$ is a dummy variable with one for central holding firms and zero for regional holding firms.

2) FDI per affiliate (FDIPA): FDIPA is given by dividing foreign equity capital of a holding firm by the number of affiliates within that holding firm. The logged value of FDIPA is used in the statistical analysis.

3) Foreign marketing control (FMC): FMC is denoted by the proportion of exported industrial output value to the total industrial output value of a holding firm.

4) $R \& D$ expenditure ( $R \& D E): R \& D E$ is the ratio of $R \& D$ expenditure to the sales revenue of a holding firm.

5) Average asset per affiliate (AAPA): AAPA is the asset of a holding firm divided by the number of its affiliates. In the regression analysis, the logged value of this variable is estimated.

6) Proportion of largest firms (PLF): PLF is the proportion of affiliates with a production-related fixed asset in excess of 50 million yuan within a holding firm. The statistical source gives the number of affiliates for seven categories broken down by the size of the production-related fixed asset: 1) below 1 million yuan, 2) between 1 and 5 million yuan, 3) between 5 and 10 
million yuan, 4) between 10 million to 30 million yuan, 5) between 30 million and 50 million yuan, 6) between 50 and 100 million yuan and 7) above 100 million yuan. The largest firm here is defined as one in excess of 50 million yuan in production-related fixe assets.

6) Coastal effect (COAST): COAST is a dummy variable with the value of one for all the holding firms located in coastal provinces and the value of zero for those located in the noncoastal provinces.

7) State equity ratio (SER): SER is given by dividing the state equity by the Chinese paid-in equity capital of a holding firm. The Chinese portion of the paid-in equity capital is derived by subtracting the foreign equity capital from the total paid-in equity capital.

8) Social liability ratio (SLR): SLR is given by dividing the non-production fixed assets of a holding firm by its total fixed assets. Both fixed asset figures are given as their original cost values. 
Table 8 Descriptive statistics of main variables

\begin{tabular}{llllll}
\hline & $\begin{array}{l}\text { Number } \\
\text { of } \\
\text { observati } \\
\text { ons }\end{array}$ & Mean & $\begin{array}{l}\text { Standard } \\
\text { deviation }\end{array}$ & $\begin{array}{l}\text { Minimum } \\
\text { value }\end{array}$ & $\begin{array}{l}\text { Maximum } \\
\text { value }\end{array}$ \\
\hline $\begin{array}{l}\text { Foreign equity ratio } \\
\text { (FER) }\end{array}$ & 62 & 0.119 & 0.123 & 0 & 0.48 \\
$\begin{array}{l}\text { FDI per affiliate } \\
\text { (FDIPA) }\end{array}$ & 62 & 4.54 & 2.67 & 0 & 9.15 \\
$\begin{array}{l}\text { Foreign marketing } \\
\text { control (FMC) }\end{array}$ & 62 & 0.093 & 0.107 & 0 & 0.703 \\
$\begin{array}{l}\text { R\&D expenditure } \\
\text { (R\&DE) }\end{array}$ & 62 & 0.022 & 0.027 & 0.0026 & 0.195 \\
$\begin{array}{l}\text { Average asset per } \\
\text { affiliate (AAPA) }\end{array}$ & 62 & 9.66 & 1.31 & 7.498 & 13.05 \\
$\begin{array}{l}\text { Proportion of largest } \\
\text { firms (PLF) }\end{array}$ & 62 & 0.307 & 0.283 & 0 & 1 \\
\hline
\end{tabular}




\section{Bibliography}

Altshuler, Alan, Martin Anderson, et al. (1986). The Future of the Automobile. Cambridge, The MIT Press.

Aswicahyono, H.H. and Hal Hill (1995). "Determinants of Foreign Ownership in Ldc Manufacturing: An Indonesian Case Study.” Journal of International Business Studies 26(1): 139-158.

Baranson, Jack (1969). Automotive Industries in Developing Countries. Washington, DC, International Bank for Reconstruction and Development.

Bauer, T (1978 ). "Investment Cycles in Planned Economies .” Acta Oeconomica 21 (3): 243260 .

Beijing Haitehua Machinery and Electric Technology Development Corporation (1994). Guojia Qiche Gongye Zhengce Xinbian [New Selections of the State's Industrial Policy Documents]. Beijing, Beijing Haitehua Machinery and Electric Technology Development Corporation.

Brandenburger, Adam M. and Barry J. Nalebuff (1997). Co-Optetion. New York, Doubleday.

Caves, Richard E. (1974). "Causes of Direct Investment: Foreign Firms' Shares in Canadian and United Kingdom Manufacturing Industries.” Review of Economics \& Statistics 56(3): 279-293.

Caves, Richard E. (1996). Multinational Enterprise and Economic Analysis. Cambridge, Cambridge University Press.

De Mello, Jr., Luiz R. (1997). "Foreign Direct Investment in Developing Countries and Growth: A Selective Survey." Journal of Development Studies 34(1): 1-34.

Donnithorne, Audrey (1981). China's Economic System. London, George Allen \& Unwin, Ltd.

Ghemawat, Pankaj (2000). Economic Evidence on the Globalization of Markets. Boston, Harvard Business School Publishing.

Gomes-Casseres, Benjamin (1990). Firm Ownership Preferences and Host Government Restrictions: An Integrated Approach. Journal of International Business Studies: 1-22.

Grosfeld, Irena (1989 ). Disequilibrium Models of Investment . Models of Disequilibrium and Shortage in Centrally Planned Economies. Christopher Charemza Davis, Wojciech W. New York, Chapman and Hall : 361-74.

Guo Wanqing (1992). "You Qiutong Zouxiang Qiuyi [from Similarities to Differentiation]." Jingji Yanjiu [Economic Research](12): 12-18.

Harrison, Mark (1985 ). "Investment Mobilization and Capacity Completion in the Chinese and Soviet Economies ." Economics of Planning 19 (2): 56-75.

Harwit, Eric (1995). China's Automobile Industry. Armonk, NY , M.E. Sharpe .

Hayek, Friedrich A. (1974 ). The Price System as a Mechanism for Using Knowledge . Comparative Economic Systems . Morris Bornstein. Homewood, IL , Richard D. Irwin, Inc. : 22-33 .

He Jianzhang and Wang Jiye (1984). Zhongguo Jihua Guanli Wenti [on Chinese Planning]. Beijing, Shehui Kexueyuan chubanshe.

Huang, Yasheng (1996). Inflation and Investment Controls in China: The Political Economy of Central-Local Relations During the Reform Era. New York, Cambridge University Press.

Huang, Yasheng (1994 ). "Information, Bureaucracy and Economic Reforms in China and in the Former Soviet Union ."World Politics 47 (1 ): 102-134 .

Huang, Yasheng and Eric Thun (1999). Shanghai Volkswagen. Boston, Harvard Business School Publishing.

Hymer, Stephen H. (1976 ). The International Operations of National Firms . Cambridge , MIT . Institute of Industrial Economy (1998). Zhongguo Gongye Fazhan Baogao 1998 [Development of Chinese Industry 1998]. Beijing, Jingji guangli chubanshe. 
Kornai, Janos (1980). The Economics of Shortage . Amsterdam, North-Holland .

Kornai, Janos (1992). The Socialist System . Princeton, Princeton University Press .

Krobin, Stephen J. (1987). Testing the Bargaining Hypothesis in the Manufacturing Sector in Developing Countries. International Organization. 41: 609-638.

Lall, Sanjaya (1978). Transnationals, Domestic Enterprises, and Industrial Structure in Host Ldcs: A Survey. Oxford Economic Papers. 30: 217-248.

Lardy, Nicholas R. (1978 ). Economic Growth and Distribution in China . Cambridge , Cambridge University Press .

Lee, Han Shih (1992). Oei Hong Leong Making Waves in Hong Kong. Business Times. Singapore: 5 .

Lieberthal, Kenneth and Michel Oksenberg (1988). Policy Making in China: Leaders, Structures and Processes. Princeton, Princeton University Press.

Lim, Soon Neo (1994). China Strategic's Profit Surges to 138 Pc to Hk\$ 153 M. Business Times.

Lindbeck, Assar (1971). The Political Economy of the New Left . New York, Harper \& Row .

Lizondo, J. Saul (1995). Foreign Direct Investment. Readings in International Business: A Decision Approach. Robert Z. Aliber and Reid W. Click. Cambridge, MIT Press: 85-112.

Luo Gengmo (1994). Shige Zhuanti Tiaocha Yanjiu [Investigative Research on Ten Issue Areas]. Dalian, Tongbei Caijing Daxue Chubanshe.

McCallum, John (1995). National Borders Matter: Canada-U.S. Regional Trade Patterns. American Economic Review. 85: 615-23.

Meredith, Lindsay (1984). "U.S. Multinational Investments in Canadian Manufacturing Industries." Review of Economics \& Statistics 66(1): 111-119.

Ministry of Machinery Industry (1991). Zhongguo Qiche Gongye Nianjian 1991 [China Automotive Statistical Yearbook 1991]. Beijing, Zhongguo qiche gongye zong gongci.

Ministry of Machinery Industry (1993). Zhongguo Qiche Gongye Nianjian 1993 [Chinese Automotive Industry Yearbook 1993]. Beijing, Ministry of Machinery Industry.

Ministry of Machinery Industry (1995). Zhongguo Qiche Gongye Nianjian 1995 [China Automotive Statistical Yearbook 1995]. Beijing, Zhongguo Qiche Jishu Yanjiu Zhongxin.

Ministry of Machinery Industry (1996). Qiche Gongye Guihua Cankao Ziliao 1996 [Reference Materials for Automotive Industry Planning 1996]. Beijing, Chinese Research Center for Automotive Technology.

Ministry of Machinery Industry (1997a). Qiche Gongye Guihua Cankao Ziliao 1997 [Reference Materials for Automotive Industry Planning 1997]. Beijing, Zhongguo Qiche Jishu Yanjiu Zhongxin.

Ministry of Machinery Industry (1997b). Zhongguo Qiche Gongye Nianjian 1997 [China Automotive Industry Yearbook 1997l. Beijing, Ministry of Machinery Industry.

Ministry of Machinery Industry (1998). Zhongguo Qiche Gongye Nianjian 1998 [China Automotive Statistical Yearbook 1998]. Beijing.

Ministry of Machinery Industry (1999). Zhongguo Qiche Gongye Nianjian 1999 [China Automotive Statistical Yearbook 1999]. Beijing, Zhongguo Qiche Jishu Yanjiu Zhongxin.

Office of Third Industrial Census (1997). The Data of the Third National Industrial Census of the People's Republic of China in 1995. Beijing, Zhongguo tongji chubanshe.

Ong, Catherine (1992). Will Oei Hong Leong Ever Shake Off Wheeler-Dealer Image? Business Times. Singapore: 3 .

Orr, Dale (1974). "The Determinants of Entry: A Study of the Canadian Manufacturing Industries." Review of Economics \& Statistics 56(1): 58-66.

Porter, Michael E. (1990). The Competitive Advantage of Nations. New York, The Free Press. 
Pratten, Clifford F. (1971). Economies of Scale in Manufacturing Industry. Cambridge, Cambridge University Press.

Pryor, F. (1972). "An International Comparison of Concentration Ratios." Review of Economics and Statistics 54: 130-140.

Qian, Yingyi and Chenggang Xu (1993). "The M-Form Hierarchy and China's Economic Reform.” European Economic Review 37: 541-548.

Rhys, D.G. (1972). The Motor Industry: An Economic Survey. London, Butterworths.

Sachs, Jeffrey D. and Andrew Warner (1995). "Economic Reform and the Process of Global Integration." Brookings Papers on Economic Activity(1): 1-95.

Schuman, Michael and Valerie Reitman (1997). Full Speed Ahead. Wall Street Journal: A1, A12.

Shen Yifeng and He Yinqi (1998). Qiye Binggou Fenxi [Analysis of Enterprise Mergers and Acquisitions]. Beijing, Zhongguo Duiwai Jingji Maoyi Chubanshe.

Sheng, Hong (1999). The Latest M\&a Cases in China. Beijing, China Light Industry Press.

Solinger, Dorothy J. (1999). Contesting Citizenship in Urban China : Peasant Migrants, the State, and the Logic of the Market. Berkeley, University of California Press.

State Bureau of Machinery Industry (1998a). 1997 Nian Jijie Gongye Zonghe Nianbao [Annual Report on the Machinery Industry 1997]. Beijing, Zhonghua renmin gonghe guo guojia jijie gongye jue.

State Bureau of Machinery Industry (1998b). Zhongguo Qiche Gongye Nianjian 1998 [China Automotive Statistical Yearbook 1998]. Tianjin, Zhongguo Qiche Jishu Yanjiu Zhongxin.

State Bureau of Machinery Industry (1999). 1998 Nian Jijie Gongye Zonghe Nianbao [Annual Report on the Machinery Industry 1998]. Beijing, Guojia jijie gongye jue.

State Council and State Planning Commission (1990). Zhongguo Gongye Xianzhuang [the Current State of Chinese Industryl. Beijing, Renmin chubanshe.

State Statistical Bureau (1997). Market Statistical Yearbook of China. Beijing, Zhongguo tongji chubanshe.

State Statistical Bureau (1999). Zhongguo Tongji Nianjian 1999 [China Statistical Yearbook 1999]. Beijing, Zhongguo tongji chubanshe.

Unirule Economic Research Institute (1997). Zhongguo Binggou Jingdian [Cases on Mergers and Acquisitions in China]. Shanghai, Xueling Chubanshe.

Upton, David and Diane Long (1996). Shanghai Volkswagen. Boston, Harvard Business School.

Wafstyl, Stefan (1996). Zf Investment in China to Rise. Financial Times.

Wang, Shaoguang and Angang Hu (1999). The Political Economy of Uneven Development: The Case of China. Armonk, NY, M.E. Sharpe.

Watson, Andrew Findlay, Christopher Du Yintang (1989 ). "Who Won the "Wool War"?: A Case Study of Rural Product Marketing in China .” The China Quarterly (118 ): 213-241.

Wedeman, Andrew (2000). Bambo Walls and Brick Ramparts: Rent Seeking, Local Protectionism, and Marketization in China, 1984-1993.

White, Lawrence J. (1971). The Automobile Industry since 1945. Cambridge, Harvard University Press.

Wong, Christine P.W. (1985 ). Material Allocations and Decentralization: Impact of the Local Sector on Industrial Reform . The Political Economy of Reform in Post-Mao China. Elizabeth Wong Perry, Christine . Cambridge , Harvard University Press : 253-278 .

Wong, Christine P.W. (1991 ). "Central-Local Relations in an Era of Fiscal Decline: The Paradox of Fiscal Decentralization in Post-Mao China ." The China Quarterly (128 ): 691-715. 
Wong, Christine P.W. (1992 ). "Fiscal Reform and Local Industrialization: The Problematic Sequencing of Reform in Post-Mao China ." Modern China 18 : 197-227 .

Wong, Christine P.W., Christopher Heady, et al. (1995). Fiscal Management and Economic Reform in the People's Republic of China. Hong Kong, Oxford University Press.

World Bank (1990). China: Macroeconomic Stability and Industrial Growth under Decentralized Socialism. Washington, DC, The World Bank.

World Bank (1994). Internal Market Development and Regulations. Washington, DC, World Bank.

World Bank (2000). World Development Report 1999/2000. Washington, DC, The World Bank. Wu Deming (1987). Guojia Yusuan Guanli Tizhi Gailun [an Outline of the Government Budget Management System]. Beijing, Zhongguo caizheng jingji chubanshe.

Xu, Xiaonian and Yan Wang (1997). Ownership Structure, Corporate Governance, and Corporate Performance. Washington, DC, World Bank.

Young, Alwyn (1997). "The Razor's Edge: Distortions and Incremental Reform in the People's Republic of China." Quarterly Journal of Economics.

Zhang Xiaoyu (1998). Zhongguo Qiche Gongye Waishang Touzi Qiye Huibian Ji Touzi Zhinan [Foreign-Invested Enterprises in Chinese Automotive Industry and Investment Guide]. Beijing, Ministry of Machinery Industry.

Zhao, Mingshan (1997). "Woguo Moxie Gongye Chanpin Shengchan Nengli Xiangdui Guosheng Yuanyin Fenxi [Analysis of Reasons for Relative Overcapacity of Production in Certain Products]." Jingji Guanli [Economic Management](220): 12-15.

Zheng Lixin (1994). Zhongguo Zhizhu Chanye Zhenxin Fanglie [Strategies of Developing China's Pillar Industries]. Beijing, Zhongguo jihua chubanshe. 


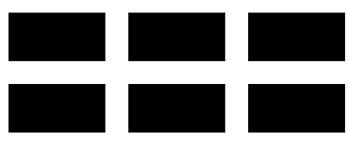

THE WiLliam DAVIDSON INSTITUTE

AT THE UNIVERSITY OF MICHIGAN BUSINESSSCHOOL

\section{DAVIDSON INSTITUTE WORKING PAPER SERIES - Most Recent Papers}

The entire Working Paper Series is available at: www.wdi.bus.umich.edu

CURRENT AS OF $5 / 10 / 01$

\begin{tabular}{|c|c|c|}
\hline Publication & Authors & Date \\
\hline No. 374 Economic Fragmentation and FDI in China & Yasheng Huang & May 2001 \\
\hline $\begin{array}{l}\text { No. } 373 \text { Earnings Disparities in the Czech Republic: Evidence of the } \\
\text { Past Decade and Cross-National Comparison }\end{array}$ & Jiri Vecernik & May 2001 \\
\hline $\begin{array}{l}\text { No. } 372 \text { Economic Reform, Democracy and Growth During Post- } \\
\text { Communist Transition }\end{array}$ & Jan Fidrmuc & Mar. 2001 \\
\hline $\begin{array}{l}\text { No. } 371 \text { Do Multinational Enterprises Substitute Parent Jobs for Foreign } \\
\text { Ones? Evidence from Firm Level Panel Data }\end{array}$ & Jozef Konings and Alan Murphye & Apr. 2001 \\
\hline $\begin{array}{l}\text { No. } 370 \text { From Needs to the Market: Changing Inequality of Household } \\
\text { Income in the Czech Transition }\end{array}$ & Jiri Vecernik & Apr. 2001 \\
\hline $\begin{array}{l}\text { No. } 369 \text { Competition and Corporate Governance: Substitutes or } \\
\text { Complements? Evidence from the Warsaw Stock Exchange }\end{array}$ & $\begin{array}{l}\text { Irena Grosfeld and Thierry } \\
\text { Tressel }\end{array}$ & Mar. 2001 \\
\hline $\begin{array}{l}\text { No. } 368 \text { Multinational Corporations as Catalyst for Industrial } \\
\text { Development: The Case of Poland }\end{array}$ & $\begin{array}{l}\text { Carlo Altomonte and Laura } \\
\text { Resmini }\end{array}$ & Feb. 2001 \\
\hline No. 367 A Multi-Task Theory of the State Enterprise Reform & $\begin{array}{l}\text { Chong-En Bai, David D. Li, } \\
\text { Zhigang Tao, and Yijiang Wang }\end{array}$ & Mar. 2001 \\
\hline No. 366 Confidence Building in Emerging Stock Markets & $\begin{array}{l}\text { Enrico C. Perotti, Luc Laeven, } \\
\text { and Pieter van Oijen }\end{array}$ & Dec. 2000 \\
\hline $\begin{array}{l}\text { No. } 365 \text { Incentive Contracting versus Ownership Reforms: Evidence } \\
\text { from China's Township and Village Enterprises }\end{array}$ & $\begin{array}{l}\text { Chun Chang, Brian McCall, and } \\
\text { Yijang Wang }\end{array}$ & Nov. 2000 \\
\hline $\begin{array}{l}\text { No. } 364 \text { Individual Pay and Outside Options: Evidence from the Polish } \\
\text { Labour Force Survey }\end{array}$ & $\begin{array}{l}\text { Fiona Duffy and Patrick Paul } \\
\text { Walsh }\end{array}$ & Mar. 2001 \\
\hline $\begin{array}{l}\text { No. } 363 \text { Investment, Credit Rationing and the Soft Budget Constraint: } \\
\text { Evidence from Czech Panel Data (revised Davidson Institute Working } \\
\text { Paper No. 60a) }\end{array}$ & Lubomír Lízal and Jan Svejnar & Feb. 2001 \\
\hline $\begin{array}{l}\text { No. } 362 \text { A Network Perspective on Inter-Organizational Transfer of } \\
\text { R\&D Capabilities: A Study of International Joint Ventures in Chinese } \\
\text { Automobile Industry }\end{array}$ & $\begin{array}{l}\text { Zheng Zhao, Jaideep Anand and } \\
\text { Will Mitchell }\end{array}$ & 2001 \\
\hline $\begin{array}{l}\text { No. } 361 \text { Network Restructuring and Firm Creation in East-Central } \\
\text { Europe: A Public-Private Venture }\end{array}$ & Gerald A. McDermott & Dec. 2000 \\
\hline $\begin{array}{l}\text { No. } 360 \text { Responses of Private and Public Schools to Voucher Funding: } \\
\text { The Czech and Hungarian Experience }\end{array}$ & $\begin{array}{l}\text { Randall K. Filer and Daniel } \\
\text { Münich }\end{array}$ & Oct. 2000 \\
\hline $\begin{array}{l}\text { No. } 359 \text { Labor Market Uncertainty and Private Sector Labor Supply in } \\
\text { Russia }\end{array}$ & Steven Stillman & Sept. 2000 \\
\hline $\begin{array}{l}\text { No. } 358 \text { Russian Roulette-Expenditure Inequality and Instability in } \\
\text { Russia, 1994-1998 }\end{array}$ & Branko Jovanovic & Sept. 2000 \\
\hline No. 357 Dealing with the Bad Loans of the Chinese Banks & John P. Bonin and Yiping Huang & Jan. 2001 \\
\hline No. 356 Retail Banking in Hungary: A Foreign Affair? & John P. Bonin and István Ábel & Dec. 2000 \\
\hline $\begin{array}{l}\text { No. } 355 \text { Optimal Speed of Transition: Micro Evidence from the Czech } \\
\text { Republic }\end{array}$ & $\begin{array}{l}\text { Stepan Jurajda and Katherine } \\
\text { Terrell }\end{array}$ & Dec. 2000 \\
\hline No. 354 Political Instability and Growth in Dictatorships & $\begin{array}{l}\text { Jody Overland, Kenneth L. } \\
\text { Simons and Michael Spagat }\end{array}$ & Nov. 2000 \\
\hline No. 353 Disintegration and Trade & Jarko Fidrmuc and Jan Fidrmuc & Nov. 2000 \\
\hline $\begin{array}{l}\text { No. } 352 \text { Social Capital and Entrepreneurial Performance in Russia: A } \\
\text { Panel Study }\end{array}$ & Bat Batjargal & Dec. 2000 \\
\hline $\begin{array}{l}\text { No. 351 Entrepreneurial Versatility, Resources and Firm Performance in } \\
\text { Russia: A Panel Study }\end{array}$ & Bat Batjargal & Dec. 2000 \\
\hline
\end{tabular}




\begin{tabular}{|c|c|c|}
\hline $\begin{array}{l}\text { No. } 350 \text { The Dynamics of Entrepreneurial Networks in a Transitional } \\
\text { Economy: The Case of Russia }\end{array}$ & Bat Batjargal & Dec. 2000 \\
\hline $\begin{array}{l}\text { No. 349a R\&D and Technology Spillovers via FDI: Innovation and } \\
\text { Absorptive Capacity }\end{array}$ & Yuko Kinoshita & Apr. 2001 \\
\hline $\begin{array}{l}\text { No. } 349 \text { R\&D and Technology Spillovers via FDI: Innovation and } \\
\text { Absorptive Capacity }\end{array}$ & Yuko Kinoshita & Nov. 2000 \\
\hline $\begin{array}{l}\text { No. } 348 \text { Microeconomic aspects of Economic Growth in Eastern } \\
\text { Europe and the Former Soviet Union, 1950-2000 }\end{array}$ & Sergei Guriev and Barry W. Ickes & Nov. 2000 \\
\hline $\begin{array}{l}\text { No. } 347 \text { Effective versus Statutory Taxation: Measuring Effective Tax } \\
\text { Administration in Transition Economies }\end{array}$ & $\begin{array}{l}\text { Mark E. Schaffer and Gerard } \\
\text { Turley }\end{array}$ & Nov. 2000 \\
\hline $\begin{array}{l}\text { No. } 346 \text { Objectives and Constraints of Entrepreneurs: Evidence from } \\
\text { Small and Medium Size Enterprises in Russia and Bulgaria }\end{array}$ & $\begin{array}{l}\text { Francesca Pissarides, Miroslav } \\
\text { Singer and Jan Svejnar }\end{array}$ & Oct. 2000 \\
\hline No. 345 Corruption and Anticorruption in the Czech Republic & $\begin{array}{l}\text { Lubomír Lízal and Evžen } \\
\text { Kočenda }\end{array}$ & Oct. 2000 \\
\hline No. 344 The Effects of Direct Foreign Investment on Domestic Firms & Jozef Konings & Oct. 2000 \\
\hline No. 343 On the Identification of Relative Wage Rigidity Dynamics & Patrick A. Puhani & Oct. 2000 \\
\hline $\begin{array}{l}\text { No. } 342 \text { The Determinants of Foreign Direct Investment in Transition } \\
\text { Economies }\end{array}$ & Alan A. Bevan and Saul Estrin & Oct. 2000 \\
\hline No. 341 The Global Spread of Stock Exchanges, 1980-1998 & Klaus Weber and Gerald F. Davis & Nov. 2000 \\
\hline $\begin{array}{l}\text { No. } 340 \text { The Costs and Benefits of Euro-isation in Central-Eastern } \\
\text { Europe Before or Instead of EMU Membership }\end{array}$ & D. Mario Nuti & Oct. 2000 \\
\hline No. 339 Debt Overhang and Barter in Russia & $\begin{array}{l}\text { Sergei Guriev, Igor Makarov and } \\
\text { Mathilde Maurel }\end{array}$ & Sept. 2000 \\
\hline $\begin{array}{l}\text { No. } 338 \text { Firm Performance and the Political Economy of Corporate } \\
\text { Governance: Survey Evidence for Bulgaria, Hungary, Slovakia and } \\
\text { Slovenia }\end{array}$ & $\begin{array}{l}\text { Patrick Paul Walsh and Ciara } \\
\text { Whela }\end{array}$ & July 2000 \\
\hline No. 337 Investment and Instability & $\begin{array}{l}\text { Nauro F. Campos a } \\
\text { Nugent }\end{array}$ & May 2000 \\
\hline $\begin{array}{l}\text { No. } 336 \text { The Evolution of the Insurance } \\
\text { Eastern Europe and the former Soviet U }\end{array}$ & Robert B.K. Pye & Aug. 2000 \\
\hline $\begin{array}{l}\text { No. } 335 \text { Institutional Technology and the Chains of Trust: Capital } \\
\text { Markets and Privatization in Russia and the Czech Republic }\end{array}$ & Spicer & Aug. 2000 \\
\hline No. 334 The Evolution of Market Integration in Russia & $\begin{array}{l}\text { Daniel Berkowitz and David N. } \\
\text { DeJong }\end{array}$ & Aug. 2000 \\
\hline No. 333 Effici & László Halpern and Gábor Körösi & July 2000 \\
\hline No. 332 Search-Money-and-Barter Models of Financial Stabilization & $\begin{array}{l}\text { S.I. Boyarchenko and S.Z. } \\
\text { Levendorskii }\end{array}$ & July 2000 \\
\hline $\begin{array}{l}\text { No. } 331 \text { Worker Training in a Restructuring Economy: Evidence from } \\
\text { the Russian Transition }\end{array}$ & $\begin{array}{l}\text { Mark C. Berger, John S. Earle } \\
\text { and Klara Z. Sabirianova }\end{array}$ & Aug. 2000 \\
\hline $\begin{array}{l}\text { No. } 330 \text { Economic Development in Palanpur 1957-1993: A Sort of } \\
\text { Growth }\end{array}$ & Peter Lanjouw & Aug. 2000 \\
\hline $\begin{array}{l}\text { No. } 329 \text { Trust, Organizational Controls, Knowledge Acquisition from } \\
\text { the Foreign Parents, and Performance in Vietnamese International Joint } \\
\text { Ventures }\end{array}$ & $\begin{array}{l}\text { Marjorie A. Lyles, Le Dang } \\
\text { Doanh, and Jeffrey Q. Barden }\end{array}$ & June 2000 \\
\hline $\begin{array}{l}\text { No. } 328 \text { Comparative Advertising in the Global Marketplace: The } \\
\text { Effects of Cultural Orientation on Communication }\end{array}$ & $\begin{array}{l}\text { Zeynep Gürhan-Canli and } \\
\text { Durairaj Maheswaran }\end{array}$ & Aug. 2000 \\
\hline No. 327 Post Privatization Enterprise Restructuring & Bornstein & July 2000 \\
\hline No. 326 Who is Afraid of Political Instability? & $\begin{array}{l}\text { Nauro F. Campos and Jeffrey B. } \\
\text { Nugent }\end{array}$ & July 2000 \\
\hline No. 325 Business Groups, the Financial Market and Modernization & Raja Kali & June 2000 \\
\hline $\begin{array}{l}\text { No. } 324 \text { Restructuring with What Success? A Case Study of Russian } \\
\text { Firms }\end{array}$ & Susan Linz & July 2000 \\
\hline $\begin{array}{l}\text { No. } 323 \text { Priorities and Sequencing in Privatization: Theory and } \\
\text { Evidence from the Czech Republic }\end{array}$ & $\begin{array}{l}\text { Nandini Gupta, John C. Ham and } \\
\text { Jan Svejnar }\end{array}$ & May 2000 \\
\hline $\begin{array}{l}\text { No. } 322 \text { Liquidity, Volatility, and Equity Trading Costs Across } \\
\text { Countries and Over Time }\end{array}$ & $\begin{array}{l}\text { Ian Domowitz, Jack Glen and } \\
\text { Ananth Madhavan }\end{array}$ & Mar. 2000 \\
\hline
\end{tabular}




\begin{tabular}{|c|c|c|}
\hline $\begin{array}{l}\text { No. } 321 \text { Equilibrium Wage Arrears: A Theoretical and Empirical } \\
\text { Analysis of Institutional Lock-In }\end{array}$ & $\begin{array}{l}\text { John S. Earle and Klara Z. } \\
\text { Sabirianova }\end{array}$ & Oct. 2000 \\
\hline No. 320 Rethinking Marketing Programs for Emerging Markets & $\begin{array}{l}\text { Niraj Dawar and Amitava } \\
\text { Chattopadhyay }\end{array}$ & June 2000 \\
\hline $\begin{array}{l}\text { No. } 319 \text { Public Finance and Low Equilibria in Transition Economies: } \\
\text { the Role of Institutions }\end{array}$ & $\begin{array}{l}\text { Daniel Daianu and Radu } \\
\text { Vranceanu }\end{array}$ & June 2000 \\
\hline $\begin{array}{l}\text { No. } 318 \text { Some Econometric Evidence on the Effectiveness of Active } \\
\text { Labour Market Programmes in East Germany }\end{array}$ & $\begin{array}{l}\text { Martin Eichler and Michael } \\
\text { Lechner }\end{array}$ & June 2000 \\
\hline No. 317 A Model of Russia's "Virtual Economy" & R.E Ericson and B.W Ickes & May 2000 \\
\hline $\begin{array}{l}\text { No. } 316 \text { Financial Institutions, Financial Contagion, and Financial } \\
\text { Crises }\end{array}$ & $\begin{array}{l}\text { Haizhou Huang and Chenggang } \\
\mathrm{Xu}\end{array}$ & Mar. 2000 \\
\hline $\begin{array}{l}\text { No. } 315 \text { Privatization versus Regulation in Developing Economies: The } \\
\text { Case of West African Banks }\end{array}$ & $\begin{array}{l}\text { Jean Paul Azam, Bruno Biais, and } \\
\text { Magueye Dia }\end{array}$ & Feb. 2000 \\
\hline $\begin{array}{l}\text { No. } 314 \text { Is Life More Risky in the Open? Household Risk-Coping and } \\
\text { the Opening of China's Labor Markets }\end{array}$ & John Giles & Apr. 2000 \\
\hline $\begin{array}{l}\text { No. } 313 \text { Networks, Migration and Investment: Insiders and Outsiders in } \\
\text { Tirupur's Production Cluster }\end{array}$ & $\begin{array}{l}\text { Abhijit Banerjee and Kaivan } \\
\text { Munshi }\end{array}$ & Mar. 2000 \\
\hline $\begin{array}{l}\text { No. } 312 \text { Computational Analysis of the Impact on India of the Uruguay } \\
\text { Round and the Forthcoming WTO Trade Negotiations }\end{array}$ & $\begin{array}{l}\text { Rajesh Chadha, Drusilla K. } \\
\text { Brown, Alan V. Deardorff and } \\
\text { Robert M. Stern }\end{array}$ & Mar. 2000 \\
\hline No. 311 Subsidized Jobs for Unemployed Workers in Slovakia & Jan. C. van Ours & May 2000 \\
\hline No. 310 Determinants of Managerial Pay in the Czech Republic & $\begin{array}{l}\text { Tor Eriksson, Jaromir Gottvald } \\
\text { and Pavel Mrazek }\end{array}$ & May 2000 \\
\hline $\begin{array}{l}\text { No. } 309 \text { The Great Human Capital Reallocation: An Empirical Analysis } \\
\text { of Occupational Mobility in Transitional Russia }\end{array}$ & Klara Z. Sabirianova & Oct. 2000 \\
\hline No. 308 Economic Development, Legality, and the Transplant Effect & $\begin{array}{l}\text { Daniel Berkowitz, Katharina } \\
\text { Pistor, and Jean-Francois Richard }\end{array}$ & eb. 2000 \\
\hline $\begin{array}{l}\text { No. } 307 \text { Community Participation, Teacher Effort, and Educational } \\
\text { Outcome: The Case of El Salvador's EDUCO Program }\end{array}$ & Yasuyuki Sawada & Nov. 1999 \\
\hline No. 306 Gender Wage Gap and Segregation in Late Transition & Stepan Jurajda & May 2000 \\
\hline $\begin{array}{l}\text { No. } 305 \text { The Gender Pay Gap in the Transition from Communism: } \\
\text { Some Empirical Evidence }\end{array}$ & Andrew Newell and Barry Reilly & May 2000 \\
\hline No. 304 Post-Unification Wage Growth in East Germany & Jennifer Hunt & Nov. 1998 \\
\hline $\begin{array}{l}\text { No. } 303 \text { How Does Privatization Affect Workers? The Case of the } \\
\text { Russian Mass Privatization Program }\end{array}$ & Elizabeth Brainerd & May 2000 \\
\hline $\begin{array}{l}\text { No. } 302 \text { Liability for Past Environmental Contamination and } \\
\text { Privatization }\end{array}$ & Dietrich Earnhart & Mar. 2000 \\
\hline No. 301 Varieties, Jobs and EU Enlargement & $\begin{array}{l}\text { Tito Boeri and Joaquim Oliveira } \\
\text { Martins }\end{array}$ & May 2000 \\
\hline No. 300 Empl & Todd Idson & Apr. 2000 \\
\hline $\begin{array}{l}\text { No. } 299 \text { Information Complements, Substitutes, and Strategic Product } \\
\text { Design }\end{array}$ & $\begin{array}{l}\text { Geoffrey G. Parker and Marshall } \\
\text { W. Van Alstyne }\end{array}$ & Mar. 2000 \\
\hline $\begin{array}{l}\text { No. } 298 \text { Markets, Human Capital, and Inequality: Evidence from Rural } \\
\text { China }\end{array}$ & $\begin{array}{l}\text { Dwayne Benjamin, Loren Brandt, } \\
\text { Paul Glewwe, and Li Guo }\end{array}$ & May 2000 \\
\hline No. 297 Corporate Governance in the Asian Financial Crisis & $\begin{array}{l}\text { Simon Johnson, Peter Boone, } \\
\text { Alasdair Breach, and Eric } \\
\text { Friedman }\end{array}$ & Nov. 1999 \\
\hline No. 296 Competition and Firm Performance: Lessons from Russia & J. David Brown and John S. Earle & Mar. 2000 \\
\hline No. 295 Wage Determination in Russia: An Econometric Investigation & $\begin{array}{l}\text { Peter J. Luke and Mark E. } \\
\text { Schaffer }\end{array}$ & Mar. 2000 \\
\hline $\begin{array}{l}\text { No. } 294 \text { Can Banks Promote Enterprise Restructuring?: Evidence From } \\
\text { a Polish Bank's Experience }\end{array}$ & John P. Bonin and Bozena Leven & Mar. 2000 \\
\hline No. 293 Why do Governments Sell Privatised Companies Abroad? & $\begin{array}{l}\text { Bernardo Bortolotti, Marcella } \\
\text { Fantini and Carlo Scarpa }\end{array}$ & Mar. 2000 \\
\hline $\begin{array}{l}\text { No. } 292 \text { Going Public in Poland: Case-by-Case Privatizations, Mass } \\
\text { Privatization and Private Sector Initial Public Offerings }\end{array}$ & Wolfgang Aussenegg & Dec. 1999 \\
\hline
\end{tabular}




\begin{tabular}{|c|c|c|}
\hline $\begin{array}{l}\text { No. 291a Institutional Technology and the Chains of Trust: Capital } \\
\text { Markets and Privatization in Russia and the Czech Republic }\end{array}$ & Bruce Kogut and Andrew Spicer & Feb. 2001 \\
\hline $\begin{array}{l}\text { No. } 291 \text { Institutional Technology and the Chains of Trust: Capital } \\
\text { Markets and Privatization in Russia and the Czech Republic }\end{array}$ & Bruce Kogut and Andrew Spicer & Mar. 1999 \\
\hline No. 290 Banking Crises and Bank Rescues: The Effect of Reputation & Jenny Corbett and Janet Mitchell & Jan. 2000 \\
\hline $\begin{array}{l}\text { No. } 289 \text { Do Active Labor Market Policies Help Unemployed Workers to } \\
\text { Find and Keep Regular Jobs? }\end{array}$ & Jan C. van Ours & Feb. 2000 \\
\hline No. 288 Consumption Patterns of the New Elite in Zimbabwe & Russell Belk & Feb. 2000 \\
\hline $\begin{array}{l}\text { No. } 287 \text { Barter in Transition Economies: Competing Explanations } \\
\text { Confront Ukranian Data }\end{array}$ & $\begin{array}{l}\text { Dalia Marin, Daniel Kaufmann } \\
\text { and Bogdan Gorochowskij }\end{array}$ & Jan. 2000 \\
\hline $\begin{array}{l}\text { No. } 286 \text { The Quest for Pension Reform: Poland's Security through } \\
\text { Diversity }\end{array}$ & $\begin{array}{l}\text { Marek Góra and Michael } \\
\text { Rutkowski }\end{array}$ & Jan. 2000 \\
\hline No. 285 Disorganization and Financial Collapse & $\begin{array}{l}\text { Dalia Marin and Monika } \\
\text { Schnitzer }\end{array}$ & Oct. 1999 \\
\hline No. 284 Coordinating Changes in M-form and U-form Organizations & $\begin{array}{l}\text { Yingyi Qian, Gérard Roland and } \\
\text { Chenggang Xu }\end{array}$ & May 1999 \\
\hline $\begin{array}{l}\text { No. } 283 \text { Why Russian Workers Do Not Move: Attachment of Workers } \\
\text { Through In-Kind Payments }\end{array}$ & Guido Friebel and Sergei Guriev & Oct. 1999 \\
\hline No. 282 Lessons From Fiascos in Russian Corporate Governance & $\begin{array}{l}\text { Merritt B. Fox and Michael A. } \\
\text { Heller }\end{array}$ & Oct. 1999 \\
\hline $\begin{array}{l}\text { No. } 281 \text { Income Distribution and } \\
\text { Safety Net During Economic Tra }\end{array}$ & $\begin{array}{l}\text { Michael Alexeev and James } \\
\text { Leitzel }\end{array}$ & Mar. 1999 \\
\hline $\begin{array}{l}\text { No. 280: Starting Positions, Reform Speed, and Economic Outcomes in } \\
\text { Transitioning Economies }\end{array}$ & William Hallagan and Zhang Jun & Jan. 2000 \\
\hline No. 279 : The Value of Prominent Directors & $\begin{array}{l}\text { Yoshiro Miwa \& J. Mark } \\
\text { Ramseyer }\end{array}$ & Oct. 1999 \\
\hline No. 278: T & nai & Apr. 1998 \\
\hline $\begin{array}{l}\text { No. 277: The Developmental Consequences of Foreign Direct } \\
\text { Investment in the Transition from Socialism to Capitalism: The } \\
\text { Performance of Foreign Owned Firms in Hungary }\end{array}$ & Lawrence Peter King & Sept. 1999 \\
\hline $\begin{array}{l}\text { No. 276: Stability and Disorder: An Evolutionary Analysis of Russia's } \\
\text { Virtual Economy }\end{array}$ & $\begin{array}{l}\text { Clifford Gaddy and Barry W. } \\
\text { Ickes }\end{array}$ & Nov. 1999 \\
\hline $\begin{array}{l}\text { No. 275: Limiting Government Predation Through Anonymous } \\
\text { Banking: A Theory with Evidence from China. }\end{array}$ & $\begin{array}{l}\text { Chong-En Bai, David D. Li, } \\
\text { Yingyi Qian and Yijiang Wang }\end{array}$ & July 1999 \\
\hline No. 274: Transition with Labour Supply & Tito Boeri & Dec. 1999 \\
\hline $\begin{array}{l}\text { No. 273: Sectoral Restructuring and Labor Mobility: A Comparative } \\
\text { Look at the Czech Republic }\end{array}$ & Vit Sorm and Kath & Nov. 1999 \\
\hline $\begin{array}{l}\text { No. 272: Published in: Journal of Comparative Economics "Returns to } \\
\text { Human Capital Under the Communist Wage Grid and During the } \\
\text { Transition to a Market Economy" Vol. 27, pp. 33-60 } 1999 .\end{array}$ & $\begin{array}{l}\text { Daniel Munich, Jan Svejnar and } \\
\text { Katherine Terrell }\end{array}$ & Oct. 1999 \\
\hline $\begin{array}{l}\text { No. 271: Barter in Russia: Liquidity Shortage Versus Lack of } \\
\text { Restructuring }\end{array}$ & $\begin{array}{l}\text { Sophie Brana and Mathilde } \\
\text { Maurel }\end{array}$ & June 1999 \\
\hline $\begin{array}{l}\text { No. 270: Tests for Efficient Financial Intermediation with Application to } \\
\text { China }\end{array}$ & Albert Park and Kaja Sehrt & Mar. 1999 \\
\hline $\begin{array}{l}\text { No. 269a: Russian Privatization and Corporate Governance: What Went } \\
\text { Wrong? }\end{array}$ & $\begin{array}{l}\text { Bernard Black, Reinier Kraakman } \\
\text { and Anna Tarassova }\end{array}$ & May 2000 \\
\hline $\begin{array}{l}\text { No. 269: Russian Privatization and Corporate Governance: What Went } \\
\text { Wrong? }\end{array}$ & $\begin{array}{l}\text { Bernard Black, Reinier Kraakman } \\
\text { and Anna Tarassova }\end{array}$ & Sept. 1999 \\
\hline No. 268: Are Russians Really Ready for Capitalism? & Susan Linz & Sept. 1999 \\
\hline No. 267: Do Stock Markets Promote Economic Growth? & $\begin{array}{l}\text { Randall K. Filer, Jan Hanousek } \\
\text { and Nauro Campos }\end{array}$ & Sept. 1999 \\
\hline $\begin{array}{l}\text { No. 266: Objectivity, Proximity and Adaptability in Corporate } \\
\text { Governance }\end{array}$ & $\begin{array}{l}\text { Arnoud W.A Boot and Jonathan } \\
\text { R. Macey }\end{array}$ & Sept. 1999 \\
\hline $\begin{array}{l}\text { No. 265: When the Future is not What it Used to Be: Lessons from the } \\
\text { Western European Experience to Forecasting Education and Training in } \\
\text { Transitional Economies }\end{array}$ & $\begin{array}{l}\text { Nauro F. Campos, Gerard } \\
\text { Hughes, Stepan Jurajda, and } \\
\text { Daniel Munich }\end{array}$ & Sept. 1999 \\
\hline
\end{tabular}

